UNIVERSIDADE DE SÃO PAULO

FACULDADE DE FILOSOFIA, LETRAS E CIÊNCIAS HUMANAS

PROGRAMA DE PÓS-GRADUAÇÃO EM GEOGRAFIA FÍSICA

LAÍS COÊLHO DO NASCIMENTO SILVA

ESTIMATIVA DE PERDA DE SOLOS POR EROSÃO LAMINAR NA BACIA HIDROGRÁFICA DO CÓRREGO BAGUAÇU NO ESTADO DE SÃO PAULO

Versão corrigida

São Paulo/SP

2015 


\title{
ESTIMATIVA DE PERDA DE SOLOS POR EROSÃO LAMINAR NA BACIA HIDROGRÁFICA DO CÓRREGO BAGUAÇU NO ESTADO DE SÃO PAULO
}

\author{
Versão corrigida
}

Tese apresentada ao Programa de Pós-Graduação em Geografia Física da Faculdade de Filosofia, Letras e Ciências Humanas (FFLCH) da Universidade de São Paulo para obtenção do título de Doutor em Ciências.

Área de concentração: Geografia Física

Orientador: Prof. Dr. Aílton Luchiari

De acordo

São Paulo/SP

2015 
SILVA, L. C. do N. Estimativa de perda de solos por erosão laminar na Bacia Hidrográfica do Córrego Baguaçu no estado de São Paulo. Tese apresentada ao Programa de Pós-Graduação em Geografia Física da Faculdade de Filosofia, Letras e Ciências Humanas (FFLCH) da Universidade de São Paulo para obtenção do título de Doutor em Ciências.

Aprovado em:

Banca Examinadora

Prof. Dr. Instituição:

Julgamento: Assinatura:

Prof. Dr. Instituição:

Julgamento: Assinatura:

Prof. Dr. Instituição:

Julgamento: Assinatura:

Prof. Dr. Instituição:

Julgamento: Assinatura:

Prof. Dr. Instituição:

Julgamento: Assinatura: 


\section{Dedicatória}

À minha querida mãe, Maria Gorete, e ao meu saudoso pai, Francisco (in memoriam). 


\section{AGRADECIMENTOS}

Meus sinceros agradecimentos:

Ao meu orientador, Prof. Dr. Aílton Luchiari, pela confiança e dedicação, apoios inestimáveis que contribuíram para o meu crescimento científico.

À Capes (Coordenação de Aperfeiçoamento de Pesquisa de Nível Superior), pelo auxílio financeiro ao longo da pesquisa.

Aos professores Dr. Jurandyr Luciano Sanches Ross e Dr. Emerson Galvani pelas sugestões e contribuições dadas no período de qualificação.

Ao professor Dr. Morel de Passos Carvalho, pela atenção e colaboração para realização da tese.

Ao colega e especialista em geoprocessamento e sensoriamento remoto, Pablo Nepomuceno, pela disponibilidade de ajuda quando necessário.

À Emplasa (Empresa Paulista de Planejamento Metropolitano).

Ao Prof. Dr. Wallace de Oliveira, pelo incentivo na carreira acadêmica.

Ao professor Célio Escher, pela detalhada e rigorosa revisão da tese.

Aos amigos que fiz ao longo desses quatro anos, Leila, Gizelle, William, Estevão e Aline. Obrigada pela amizade e pelo companheirismo! 
À minha família: Gorete, Francisco, Thaís, Tatiane e tia Bal, que sempre me apoiaram. A todos os meus familiares, em especial à Tia Korrinha e ao tio Silvano, pela companhia em saída de campo, e à tia Maria, pela hospedagem e companhia. 


\section{RESUMO}

SILVA, L. C. do N. Estimativa de perda de solos por erosão laminar na Bacia Hidrográfica do Córrego Baguaçu no estado de São Paulo. 2015. 135 f. Tese (Doutorado) - Faculdade de Filosofia, Letras e Ciências Humanas, Universidade de São Paulo, São Paulo, 2015.

A erosão é um fenômeno natural no modelado da superfície, no processo de remoção e de deposição de sedimentos, porém as atividades antrópicas, como o desmatamento, excedem os níveis naturais de perdas de solo. Para estimar a perda de solo anual em terrenos agricultáveis, existem modelos de predição, que relacionam elementos físicos da paisagem junto às atividades antrópicas existentes. Nessa temática, o objetivo deste trabalho é avaliar a perda de solos na Bacia Hidrográfica do Córrego Baguaçu, localizada no oeste do estado de São Paulo, considerada uma região de intensa erosão acelerada, resultado de solos provenientes de materiais arenosos e areno-argilosos de fácil erosão, isso aliado às pressões de uso agropecuário. A EUPS (Equação Universal de Perda de Solos) foi o modelo de predição utilizado para estimar a perda de solos superficiais nessa bacia. A EUPS permite avaliar o resultado dos produtos da erosividade da chuva, erodibilidade do solo, fator topográfico, cobertura do uso do solo, manejo e práticas conservacionistas. Utilizando o Sistema de Informação Geográfica (SIG), foi possível estimar espacialmente as áreas de maior vulnerabilidade a erosão, além de mapear feições lineares erosivas e apontar qual uso é mais responsável por grandes perdas de solos. Os resultados mostraram que grande parte da perda de solos na bacia concentra-se nas classes mais baixas ( 0 a 3 t/ha/ano), com predomínio das áreas ocupadas com pastagem e com cana-de-açúcar.

Palavras-chave: Erosão acelerada; EUPS; SIG. 


\section{ABSTRACT}

SILVA, L. C. do N. Estimating soil loss by sheet erosion in the basin of Córrego Baguaçu in São Paulo state. 2015. $135 \mathrm{f}$. Tese (Doutorado) Faculdade de Filosofia, Letras e Ciências Humanas, Universidade de São Paulo, São Paulo, 2015.

Erosion is a natural phenomenon in the modeled the surface removal process and sediment deposition, but human activities, such as deforestation, exceed natural levels of soil loss. To estimate the annual soil loss in arable land, there are models of prediction, which relate to physical elements of the landscape with anthropogenic activities. On this subject, the aim of this study is to evaluate the loss of soils in the watershed of Córrego Baguaçu, located in the west of the State of São Paulo, considered a region of intense accelerated erosion, result of soils from sandy and sandy-clay materials of easy erosion, that ally to the pressures of agricultural use. The USLE (Universal Soil loss Equation) was the prediction model used to estimate the loss of surface soils in this basin. The USLE allows you to evaluate the outcome of rainfall erosion index, soil erodibility, topographic factor, coverage of land use, management and conservation practices. Using the Geographical Information System (GIS), it was possible to estimate spatially the areas of greatest vulnerability to erosion, as well as linear features map changes and point out what is most responsible for heavy losses from soils. The results showed that much of the soil loss in the concentrates on lower classes ( 0 to $3 \mathrm{t} / \mathrm{ha} / \mathrm{yr}$ ), with predominance of the occupied areas with pasture and sugar cane.

Keywords: accelerated erosion; USLE; GIS. 


\section{LISTA DE FIGURAS}

Figura 1 - Representação esquemática de um sistema................................ 19

Figura 2 - O sistema em uma vertente convexo-retílinia-côncava..................... 23

Figura 3 - Mapa de localização da BBT.................................................. 49

Figura 4 - Mapa geológico da BBT........................................................... 53

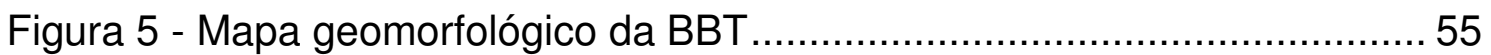

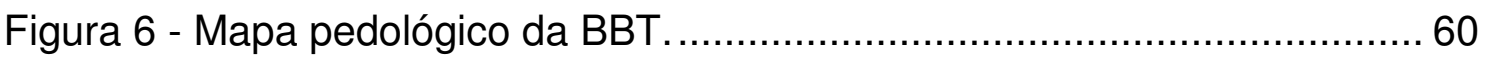

Figura 7 - Representação das feições climáticas do Estado de São Paulo. .... 62

Figura 8 - Fluxograma com etapas para obtenção da EUPS. ........................... 65

Figura 9 - Intervalo de confiança da precipitação média mensal de Araçatuba (SP) e Votuporanga (SP) no período de 1975 a 1996.................................. 79

Figura 10 - Fator K dos solos da Bacia Hidrográfica do Córrego Baguaçu. .... 84

Figura 11 - Mapa de declividade do Córrego Baguaçu. ................................. 87

Figura 12 - Mapa de comprimento de rampa do Córrego Baguaçu. ................. 88

Figura 13 - Mapa de fator topográfico do Córrego Baguaçu. ........................... 90

Figura 14 - Uso e ocupação do solo na Bacia Hidrográfica do Córrego

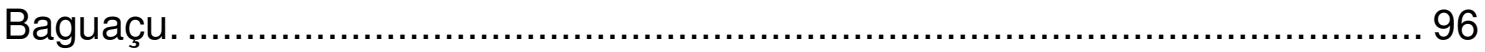

Figura 15 - Fator P da Bacia Hidrográfica do Córrego Baguaçu. .................... 98

Figura 16- Potencial natural a erosão - PNE do Córrego Baguaçu. ............... 101

Figura 17 - Expectativa à erosão laminar na Bacia Hidrográfica do Córrego

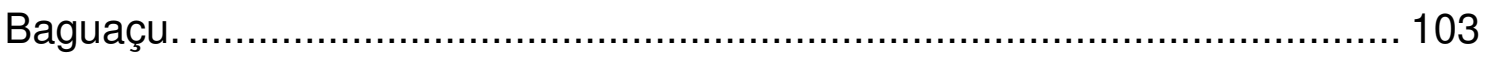

Figura 18 - Perda de solos por erosão na Bacia Hidrográfica do Córrego

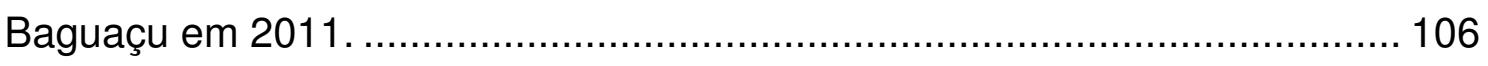

Figura 19 e 20 - Corte da estrada sob afluente na margem esquerda do Córrego Baguaçu...................................................................................... 109

Figura 21 - Afluente Córrego Baguaçu....................................................... 1

Figura 22 - Curso d'água canalizado em área urbana ................................ 110 
Figura 23 - Afluente do Córrego Baguaçu.................................................. 110

Figura 24 - Parque Ecológico Baguaçu ......................................................... 110

Figura 25 - Feições erosivas na Bacia Hidrográfica do Córrego Baguaçu em 2011. 111 


\section{LISTA DE TABELAS}

Tabela 1 - Estágios de desenvolvimento da cultura para composição do fator C.

Tabela 2 - Principais características dos solos do Córrego Baguaçu. 56

Tabela 3 - Propriedades físicas e químicas dos solos presentes na Bacia Hidrográfica do Córrego Baguaçu 67

Tabela 4 - Chave de fotointerpretação do uso e ocupação do solo. 69

Tabela 5: Razão de perda de solos para culturas da Bacia Hidrográfica do Córrego Baguaçu. 72

Tabela 6 - Razão de perda de solos para o eucalipto 73

Tabela 7 - Valores de P da equação de perda de solos para algumas práticas conservacionistas. 74

Tabela 8 - Chave de fotointerpretação das práticas conservacionistas. 74

Tabela 9 - Chave de fotointerpretação de erosão laminar. 77

Tabela 10 - Valores médios mensais e médios anuais de precipitação pluviométrica, coeficientes de chuva e índices de erosividade médios mensais de Araçatuba (SP) entre o período de 1971 a 2000. 80

Tabela 11 - Distribuição mensal relativa do índice de erosividade $\mathrm{El}_{30}$ de Araçatuba (SP) durante o período de 1971 a 2000. 81

Tabela 12- Erodibilidade dos solos do Córrego Baguaçu e área ocupada pelas classes. 85

Tabela 13 - Classes de declividade do Córrego Baguaçu. 86

Tabela 14 - Classes de comprimento de rampa do relevo do Córrego Baguaçu.

Tabela 15 - Classes de fator topográfico do Córrego Baguaçu. 89

Tabela 16 - Áreas das classes de uso e ocupação do solo. 92 
Tabela 17 - Classes de uso e ocupação do Córrego Baguaçu e respectivo valor de Fator $\mathrm{C}$.

Tabela 18 - Práticas conservacionistas da Bacia Hidrográfica do Córrego Baguaçu.

Tabela 19 - Classes de PNE e área ocupada na Bacia Hidrográfica do Córrego Baguaçu.

Tabela 20 - Discordância positiva e negativa em relação ao uso e ocupação do Córrego Baguaçu. 102

Tabela 21 - Perda de solos em t/ha.ano da Bacia Hidrográfica do Córrego Baguaçu 104

Tabela 22 - Áreas em porcentagem de perda de solos associadas ao uso e ocupação do solo na Bacia Hidrográfica do Córrego Baguaçu. 107

Tabela 23 - Relação de perda de solos com os solos da Bacia Hidrográfica do Córrego Baguaçu. 


\section{LISTA DE APÊNDICE}

APÊNDICE A - Distribuição mensal e anual da precipitação pluviométrica de

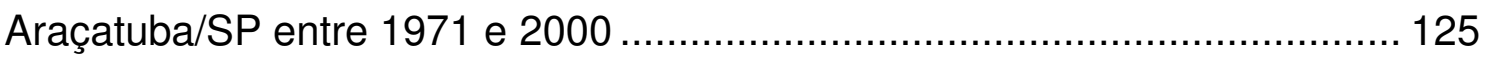

APÊNDICE B - Distribuição mensal e anual dos índices de erosividade de

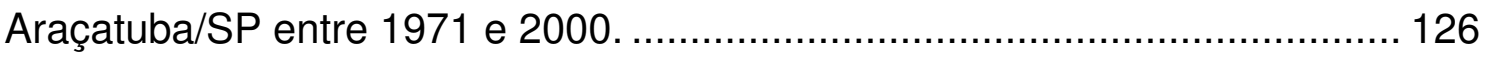

APÊNDICE C - ei30 médio, absoluto, absoluto acumulado e relativo

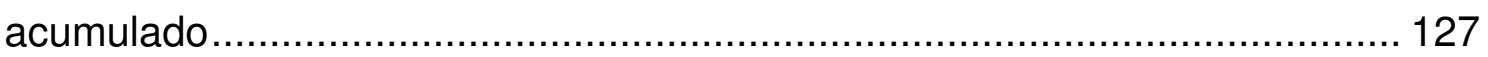

APÊNDICE D - Cana planta de ano em preparação convencional ................. 127

APÊNDICE E - Cana planta de ano e meio em preparação convencional..... 128

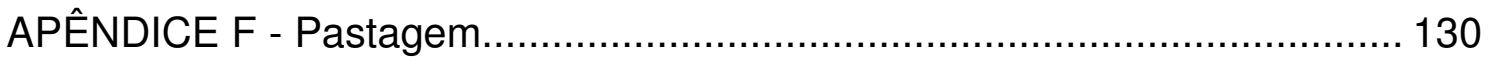

APÊNDICE G - Milho em cultivo contínuo com palha enterrada ................... 131

APÊNDICE H - Soja em cultivo convencional e contínuo .............................. 132

APÊNDICE I - Eucalipto ciclo para celulose................................................. 132

APÊNDICE J - Script em Legal Fator LS.................................................. 132

APÊNDICE K - Script em Legal Fator CP ................................................ 133

APÊNDICE L - Script em Legal CP atual -CP tolerável ............................... 133

APÊNDICE M - Script em Legal Potencial Natural a erosão PNE.................. 134

APÊNDICE N - Script em Legal EUPS Baguaçu......................................... 134 


\section{LISTA DE SIGLAS}

DAEE - Departamento de Águas e Energia Elétrica

EUPS - Equação Universal de Perda de Solos

GPS - Sistemas de Posicionamento Global

IBGE - Instituto Brasileiro de Geografia e Estatísticas

INPE - Instituto de Pesquisas Espaciais

LEGAL - Linguagem Espacial para Geoprocessamento Algébrico

MEUPS / MUSLE - Modified Universal Soil Loss Equation

NDVI - Índice de Vegetação de Diferença Normalizada

PEBA - Parque Ecológico Baguaçu

PNE - Potencial Natural de Erosão

RPS - Razão de Perda de Solos

RUSLE - Revised Universal Soil Loss Equation

SIG - Sistema de Informação Geográfica

SRTM - Shuttle Radar Topography Mission

SWAT - Soil and Water Assessment Tool

UGRHI - Unidade de Gerenciamento dos Recursos Hídricos

USLE - Universal Soil Loss Equation

UTM - Universal Transversa de Mercator

WEPP - Water Erosion Prediction Project

WGS - World Geodetic System 
1 INTRODUÇÃO

2 PROCESSOS EROSIVOS EM BACIA HIDROGRÁFICA E USO DE

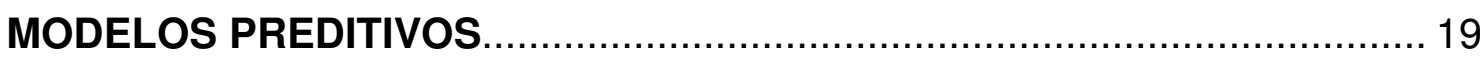

2.1 Sistema Bacia Hidrográfica e Erosão .................................................... 19

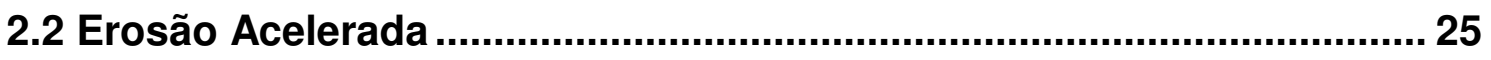

2.3 Estudo da Erosão em Bacia Hidrográfica com Aplicação de Modelos de Perdas de Solos ............................................................................... 27

2.3.1 Fator R: Potencial erosivo das chuvas ............................................... 31

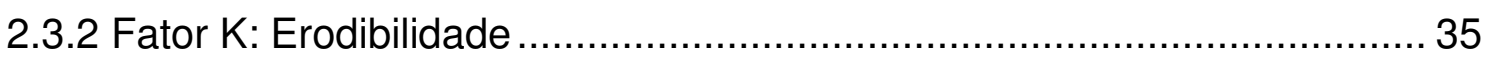

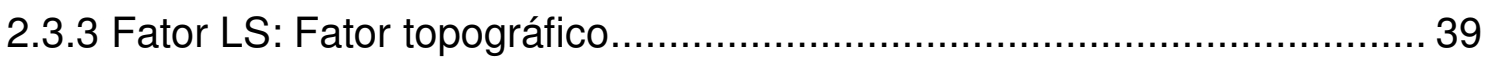

2.3.4 Fator CP: Uso e manejo dos solos e práticas conservacionistas ............ 43

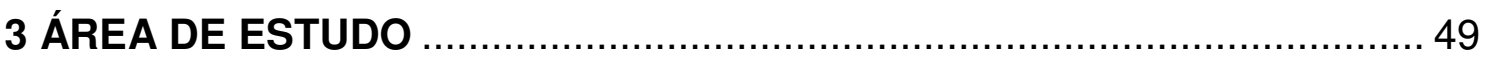

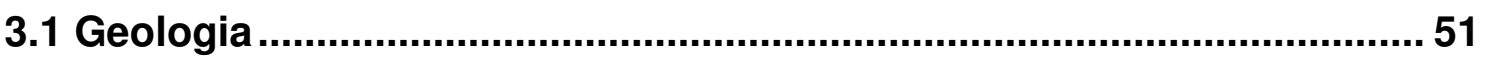

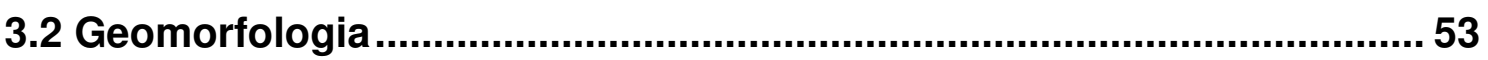

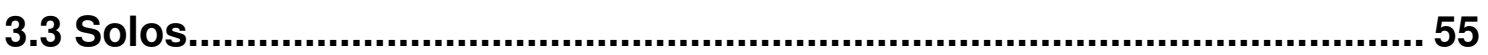

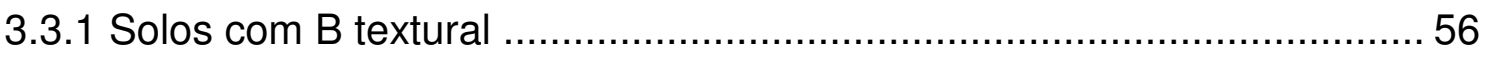

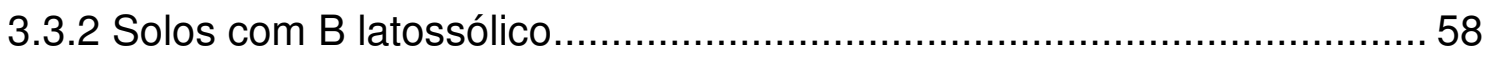

3.4 Clima

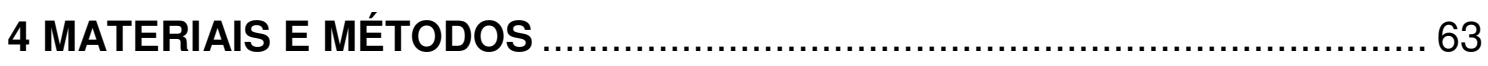

4.1 Equação Universal de Perdas de Solos (EUPS) ...................................... 63

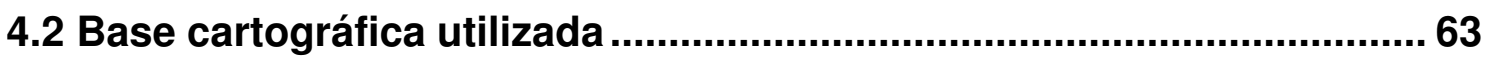

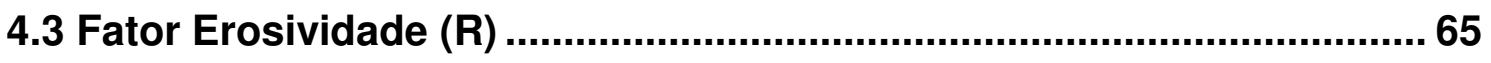

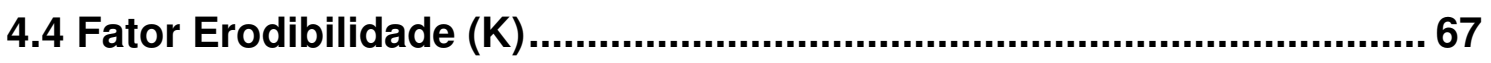

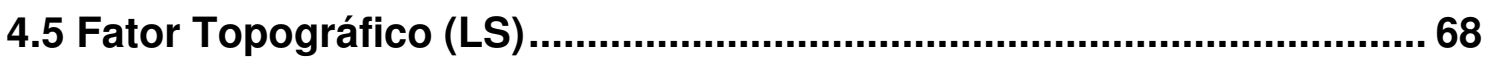

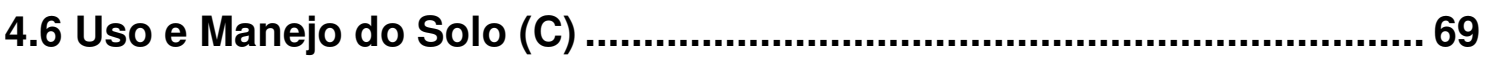




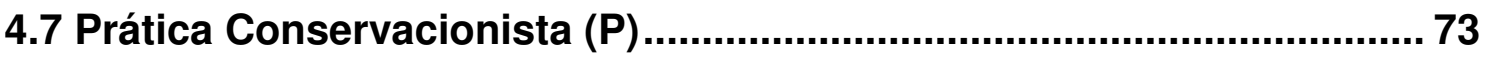

4.8 Potencial Natural a Erosão- PNE............................................................ 74

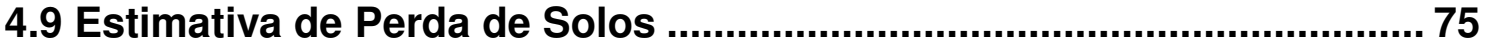

4.10 Expectativa à Erosão Laminar em Função dos Fatores Antrópicos.. 76

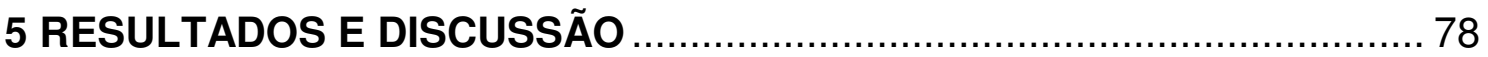

5.1 Fator R

5.2 Fator K

5.3 Fator LS

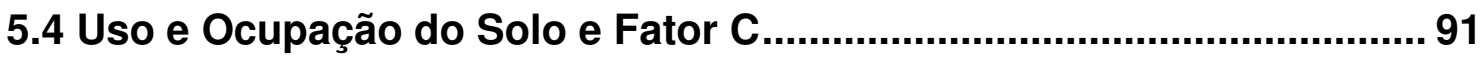

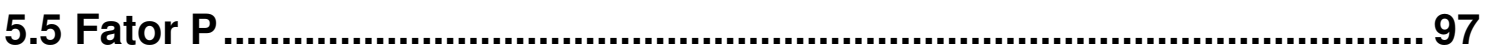

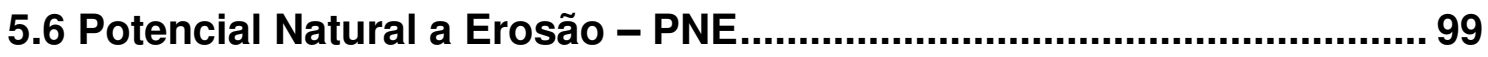

5.7 Estimativa de Erosão Laminar em Função de Fatores de Ocupação do

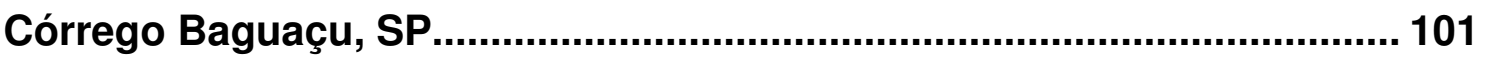

5.8 Equação Universal de Perda de Solos (EUPS) ................................... 104

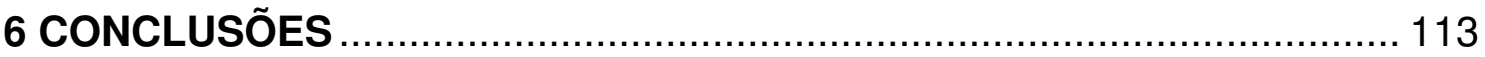

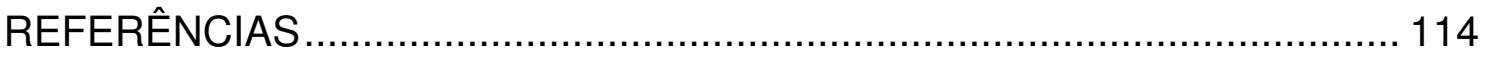

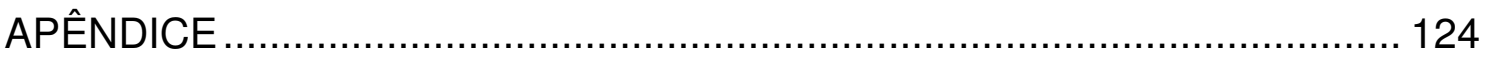




\section{INTRODUÇÃo}

Os processos erosivos têm sido assunto de grande preocupação na comunidade acadêmica, atentando sobre os recorrentes estudos acerca de toneladas de perdas de solos agricultáveis durante o ano e evidenciando as inúmeras formas erosivas, que se tornaram, em alguns locais, corriqueiras e triviais. As perdas são significativas e as consequências, muitas vezes, são irreparáveis, sendo que práticas conservacionistas de manejo bem feitas seriam de grande ajuda para evitar que solos se tornem improdutivos futuramente.

O solo constitui-se de uma fina camada de material que recobre a superfície terrestre. Essa camada de material é resultante da desagregação de partículas de rochas que, juntamente com o intemperismo físico, químico e biológico, geraram camadas a que, tecnicamente, nomeamos horizontes. Assim, o solo é resultado da evolução que a rocha, exposta ao tempo, teve ao longo de seu processo dinâmico. Vale dizer que o solo é o resultado de como a ação intempérica agiu sobre a rocha de diferentes modos e em sucessivos períodos de tempo.

Tendo os solos essa origem, cabe afirmar que a erosão dos solos é um fenômeno natural, de caráter geológico, agindo na crosta terrestre como um processo benéfico para a renovação desses solos e a formação da sua diversidade (PRUSKI, 2009). Essa renovação e diversificação ocorre de forma muito lenta, já que a cobertura natural (vegetação) protege cada horizonte, havendo um constante equilíbrio na formação do solo e no desgaste erosivo. Diferentemente, porém, a ação antrópica no meio ambiente acelera esse processo, em especial ao remover a vegetação natural. Havendo a remoção da vegetação, o solo fica desprovido de proteção, estando sujeito a fatores de depauperamento. Esse empobrecimento do solo vai depender da intensidade e da velocidade de degradação, fatores que variam de acordo com as próprias características de cada solo, além do clima, do relevo e da variedade de ações antrópicas praticadas (LEPSCH, 2011). 
O solo é um recurso natural imprescindível para a manutenção e a sobrevivência da humanidade, pois o uso por demais intensivo ou mesmo por demais extensivo, sem adoção de práticas conservacionistas, reduz ou faz perder a sua capacidade de produção de alimentos de origem vegetal, fator esse diretamente relacionado à escassez de alimentos e à fome (BERTONI e LOMBARDI NETO, 2012).

Outros problemas estão relacionados à erosão do solo além da inutilização de áreas agricultáveis por motivo de erosão. Pode-se citar, dentre esses outros problemas, o assoreamento de canais de águas fluviais, a compactação dos solos, a remoção de nutrientes da camada superficial do solo e a poluição hídrica. São todos fatores que causam enormes prejuízos relacionados à perda de produtividade, a custos com corretivos e fertilizantes e à geração de energia para irrigação, entre outros fatores.

O uso de modelos preditivos de perda de solos por erosão e por deposição de sedimentos pelo uso agrícola, como, por exemplo, a USLE (Universal Soil Loss Equation) (WISCHMEIER e SMITH, 1978), é amplamente utilizada (TAVARES, 1986; MENDES, 1993; LUCHIARI, 1994; MITASOVA et al., 1996; JAIN e KOTHYARI, 2000; LAGROTTI, 2000), seja em estudos aplicados a bacias hidrográficas ou a glebas experimentais.

Além da USLE, existem outros modelos, como a RUSLE (Revised Universal Soil Loss Equation), a SWAT (Soil and Water Assessment Tool) e WEPP (Water Erosion Prediction Project), que, aplicados em SIG (Sistemas de Informação Geográfica), representam uma ferramenta que permite a caracterização da paisagem, simulação dos processos e distribuição dos fenômenos (MITASOVA et al., 1997) consistindo numa forma prática de tomada de decisões, que visa minimizar os impactos gerados pela agricultura intensiva.

Diante do exposto, o presente estudo tem como objetivo geral identificar áreas de maior susceptibilidade da Bacia Hidrográfica do Córrego Baguaçu ${ }^{1}$ frente às mudanças agrícolas por que a bacia tem passado e quantificar a perda de solos atual na bacia, utilizando geotecnologias e modelo preditivo.

\footnotetext{
${ }^{1}$ Por questão de economia de linguagem, daqui para frente, neste trabalho, será escrito, simplesmente: Bacia do Córrego Baguaçu, Bacia do Rio Paranapanema, etc.
} 
A hipótese do trabalho é a de que a exploração agrícola e pecuária aumentem a degradação dos solos, sendo estimados na perda de solos dos usos atuais referentes a bacia do Córrego Baguaçu.

Os objetivos específicos vêm ao encontro do objetivo geral, sendo eles:

(a) determinar a perda de solos provenientes de erosão superficial (hídrica) na bacia do Córrego Baguaçu através da Equação Universal de Perda de Solos (EUPS) utilizando um Sistema de Informação Geográfica;

(b) avaliar áreas de maior fragilidade quanto ao uso e aos processos erosivos,

A escolha da área de estudo, que, neste caso, é a Bacia do Córrego Baguaçu, se deu devido à sua localização na porção oeste do estado de São Paulo, região que apresenta problemas com processos erosivos inerentes às características naturais dos solos locais, mas também pelo histórico de transformação antropogênica acelerada e desordenada ali registrada (TAVARES, 1986). De acordo com Tavares (1986), os problemas pelos quais o Planalto Ocidental tem passado, associados à erosão, causam perda de fertilidade natural dos solos, assoreamento dos canais fluviais, destruição de estradas e geração de voçorocas, sendo tudo resultado do arraste de toneladas de terras das camadas superficiais dos solos.

A Bacia do Córrego Baguaçu também é responsável, em grande parte, pelo abastecimento de água da população de Araçatuba, uma das maiores cidades do oeste paulista. Assim, essa bacia hidrográfica, sendo ocupada predominantemente por uso agropecuário, gera a necessidade conhecimento da área para a avaliação dos impactos gerados por esse uso a fim de se propor projetos de planejamento para qualificadas práticas conservacionistas de preservação e de recuperação do solo. 


\section{PROCESSOS EROSIVOS EM BACIA HIDROGRÁFICA E USO DE MODELOS PREDITIVOS}

\subsection{Sistema Bacia Hidrográfica e Erosão}

A abordagem sistêmica - estudada na área de conhecimento científico e consistindo na organização dos elementos e sua interação - caracteriza um estudo reducionista e holístico ao mesmo tempo, pois, ao início de estudos de uma área sistêmica, a preocupação é conhecer e entender primeiramente os elementos que a compõem (abordagem reducionista), para depois levar em consideração o todo (abordagem holística) (CHRISTOFOLETTI, 1999). Assim, a abordagem sistêmica serve bem ao geógrafo, pois consiste num instrumento conceitual que facilita tratar dos conjuntos complexos, como os da organização espacial (CHRISTOFOLETTI, 1982).

Em um sistema existem os seus elementos, ou partes componentes (A, $B, C$ e D), que se relacionam uns com os outros, numa relação de dependência, através de ligações que apontam o fluxo. A entrada (input) constitui tudo aquilo que o sistema recebe, ou seja, a alimentação desse sistema. Na saída (output) é excretado todo material que foi recebido pela entrada, porém modificado com as relações sofridas em seu interior (Figura 1).

Figura 1 - Representação esquemática de um sistema, assinalando os elementos (A, B, C e D) e suas relações, assim como o evento entrada e 0 produto saída.

Fonte: CHRISTOFOLETTI (1979, p. 2). 
Segundo Morisawa (1985), a bacia hidrográfica é considerada um sistema, pois seus muitos componentes são constantemente modificados, sendo que cada elemento interage com outro(s), caracterizando um sistema complexo. A autora ainda afirma que os rios e os processos fluviais constituem, provavelmente, o mais importante sistema geomorfológico na superfície terrestre.

Christofoletti (1979) considera as bacias hidrográficas organizadas para escoar quantidades de água e detritos que são carreados para a sua área de drenagem, já que os sistemas são organizados para realizar uma tarefa no ambiente.

Ao considerar a bacia como um sistema aberto que se encontra em equilíbrio dinâmico, Yang e Stall (1981) justificam o uso do conceito de entropia para a explicação de alguns fenômenos morfológicos observados no sistema de bacias hidrográficas. Christofoletti (1979) afirma que o conceito de entropia pode ser empregado nos sistemas desde que haja fluxos de matéria e energia iniciando o funcionamento do sistema, pois, no início de qualquer sistema, há desigualdade e desorganização quanto à distribuição de energia.

Rocha (2011) exemplifica o conceito de entropia da termodinâmica no caso do sistema de bacias hidrográficas:

Das suas nascentes até a sua foz, um canal fluvial natural essencialmente representa um sistema no qual a energia potencial é proveniente de certa quantidade de água das áreas mais elevadas, convertida em energia cinética pelo fluxo da água e dissipada na fricção criada pelas paredes do canal e atmosfera. A importância neste caso é dada à distribuição de energia ao longo do rio, apesar da energia total ser também importante no desenvolvimento da paisagem. Em analogia com as leis da termodinâmica, essa distribuição pode ser descrita como entropia, considerando que a entropia de um sistema é função da distribuição de energia disponível dentro do sistema, e não uma função da energia total dentro do sistema. (ROCHA, 2011, p. 215).

De acordo com Morisawa (1985), a bacia hidrográfica é um sistema processo-resposta tão integrado que uma mudança em alguma parte da bacia necessita de uma resposta e essa resposta pode ocorrer em qualquer lugar. 
Ocorre, porém, que esse balanço de formas e processos é inexato e flutuante, pois há muitas variáveis inter-relacionadas e as respostas para os estímulos podem apresentar-se indeterminadas.

Chorley (1973) descreve a importância dos fatores que, de maneira geral, controlam o regime dos rios, quando esses fatores são explicados como elementos de num sistema. Assim, primeiro, o clima influencia na sequência mensal de precipitação (positiva) e os valores de insolação e radiação solar (negativa), controlando a evaporação. Em segundo lugar entra a vegetação, cujo papel é diminuir o escoamento superficial. Depois se consideram os solos e a estrutura da rocha, em especial suas propriedades de permeabilidade, ou seja, a capacidade de reter a água. Por fim, entra a geometria hidráulica da bacia hidrográfica, pois a forma e o gradiente da rampa influenciam no escoamento.

Os componentes que irão caracterizar um sistema são: a matéria, a energia e a estrutura. A matéria corresponde ao material que vai ser mobilizado através do sistema; a energia remete às forças que irão fazer o sistema funcionar, gerando capacidade de realizar o trabalho; e a estrutura, que é constituída pelos elementos e suas relações (CHRISTOFOLETTI, 1979). No caso do sistema de bacia hidrográfica:

Para o caso das bacias hidrográficas, as condições climáticas, geológicas e biogeográficas constituem o seu ambiente. Desta maneira, os parâmetros relevantes que descrevem fornecimentos para as bacias de drenagem são os relacionados com a quantidade de calor (expressa pela temperatura), de precipitação (chuvas, neves etc.), área e volume dos afloramentos litológicos, área e densidade da cobertura vegetal, profundidade do manto de alteração e outros mais. (CHRISTOFOLETTI, 1979, p. 7).

O autor discorre acerca da importância da rede de canais e das vertentes como principais elementos da bacia hidrográfica. Nessa paisagem, considera que a estruturação da rede de canais é reflexo do comportamento hidrológico, além dos diversos tipos de controles atuantes (CHRISTOFOLETTI, 1979).

O ciclo da bacia pode ser visto, simplesmente, como input de precipitação, sendo distribuído através de armazenadores por uma série de 
transferências, enviados para outputs por meio de escoamento superficial e de infiltração (CHORLEY, 1973).

De acordo com Christofoletti (1978), os sistemas são dinâmicos, sendo capazes de se modificar continuamente, alterando as transferências de massa e de energia no sistema. O autor sugeriu alguns questionamentos, como:

-O nível de energia do sistema aumentará no próximo período? ou

-A energia se manterá constante? ou, ainda,

-A energia diminuirá?

Essas perguntas podem ser transferidas para o sistema de uma bacia hidrográfica. Considerando uma bacia em equilíbrio, sem interferência antrópica, o sistema estará em equilíbrio quanto à entrada e à saída de energia. Os fatores externos, de entrada de energia, são os fatores climáticos, que são impulsionados pela gravidade, ou seja, é a energia potencial - a energia inicial - que leva ao funcionamento do processo (CHRISTOFOLETTI, 1978).

O sistema vertente dessa bacia possuiria cobertura vegetal na alta vertente, sendo uma barreira para que a água da chuva encontre o solo, pois minimizaria o processo erosivo de saltitação do solo ao impacto das gotas de chuvas e facilitaria a infiltração da água para armazenamento no lençol freático. A porção de água que não é infiltrada no solo é escoada superficialmente, carreando sedimentos para pequenas depressões ao longo da vertente. Esse material mobilizado corresponde à matéria, representada pela água e pelos detritos, ou seja, material da precipitação, da rocha subjacente e da vegetação. Estando em movimento, esse material é passivo de energia cinética, aliando-se à energia potencial, ou seja, da gravidade. De acordo com Christofoletti (1978), esses armazenamentos de massa e de energia constituem algo como reservas ao funcionamento do sistema.

Na Figura 2 são mostrados os fatores e as relações do sistema vertente: 


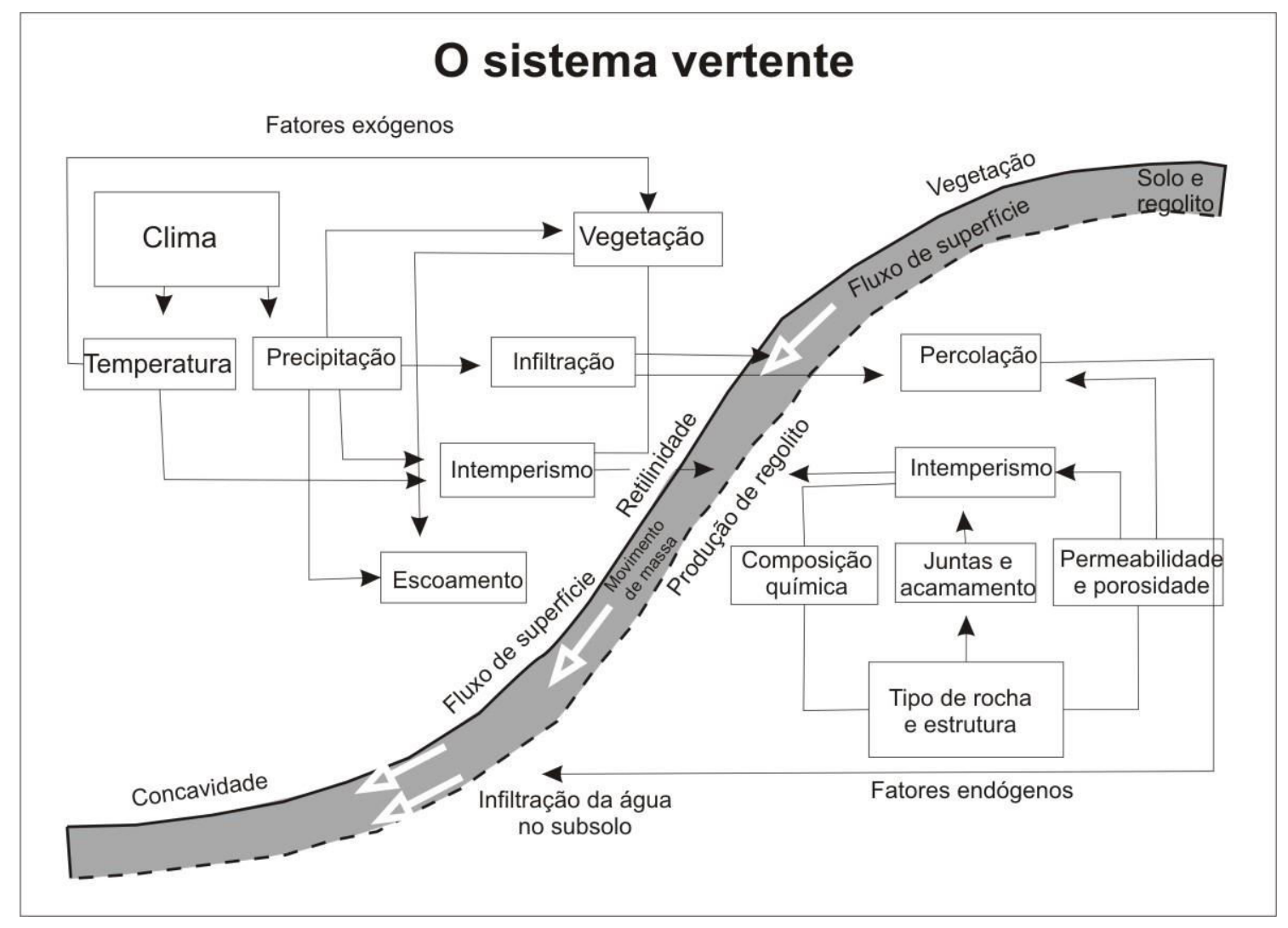

Figura 2 - O sistema em uma vertente convexo-retílinia-côncava. Fonte - Clark \& Smal, 1982 apud Casseti, 2005.

Na média vertente, o processo de entrada de energia é o mesmo que o anterior. A diferença está nos armazenadores de matéria, pois o subsolo se encontra já saturado pela água vinda da parte mais alta da vertente e há maior acúmulo de material transportado superficialmente. O material é transportado e/ou armazenado nas planícies de inundação, nos leitos, ou é transportado para lagos e mares (CHRISTOFOLETTI, 1978), configurando um processo de evolução da paisagem. Yang e Stall (1981) explicam que o sistema da bacia constantemente ajusta a geometria e o perfil para manter um equilíbrio dinâmico entre os índices de transporte e de carga de sedimentos depositados, configurando diferentes estágios de desenvolvimento das formas do leito.

Considerando uma bacia hidrográfica passível aos fatores antrópicos, como a retirada da vegetação e sua substituição pelo uso agrícola e agropecuário, os processos erosivos são diferenciados e intensificados. Podese considerar uma bacia hidrográfica onde grande parte é ocupada por pastagem e culturas como cana-de-açúcar, além de outras interferências 
humanas, como abertura de estradas, expansão da agricultura, ausência de práticas consevacionistas, desmatamento, urbanização, entre outros, que modificam as condições naturais de um sistema hidrológico (RENNÓ, 2003).

No subsistema vertente dessa bacia, quando as chuvas fortes atingirem a superfície sem que o impacto direto seja impedido por uma vegetação, o material fino será jogado em suspensão por esse impacto e será depositado novamente como uma pele de superfície quase impermeável que pode diminuir a infiltração em até 10 vezes (CHORLEY,1973).

Como consequência dessa impermeabilização, os armazenadores de material e energia são prejudicados, pois o pisoteio do gado, por exemplo, gera compactação do mesmo, diminuindo a capacidade de infiltração das águas, reduzindo a circulação de água na subsuperfície e o abastecimento do lençol freático (RODRIGUES e MOROZ - CACCIA GOUVEIA, 2013). O tipo de solo também influenciará nos processos de infiltração da bacia, sendo importante considerar que as retiradas da vegetação natural e da cobertura de matéria orgânica também contribuem para a desagregação dos compontentes do solo.

Sendo assim, é possível afirmar que as alterações antrópicas no sistema da bacia de drenagem produzem mudanças no sistema de processos e de respostas:

\begin{abstract}
Por exemplo, aumentando a capacidade de infiltração de determinada área, haverá diminuição no escoamento superficial e na densidade de drenagem, o que reflete na diminuição da declividade das vertentes. Essa diminuição por sua vez, facilita a capacidade de infiltração e diminui o escoamento superficial. Ao contrário, diminuindo a capacidade de infiltração de uma área, haverá aumento do escoamento superficial e da densidade de drenagem, o que reflete em maior declividade das vertentes. Esse aumento, por sua vez, irá dificultar a capacidade de infiltração e aumentar o escoamento superficial. (CHRISTOFOLETTI, 1980, p. 5).
\end{abstract}

Alterando alguma função de um componente do sistema, tal sistema imediatamente passa a buscar um equilíbrio, reajustando-se numa nova forma.

Os fatores fisiográficos ou morfoestruturais da bacia hidrográfica também são características que auxíliam na dedução dos processos que levaram à construção de suas formas atuais, assim como a área da bacia, a forma, a permeabilidade e a capacidade de infiltração (VILLELA e MATTOS, 
1975). A área e a forma da bacia decidem a quantidade de água que a bacia pode captar e a sua tendência a enchentes.

Os fatores de alteração antrópica, como o desmatamento, alteram o clima, influenciando nos eventos de processos erosivos. Primavesi (1990) afirma que, em locais desprovidos de florestas, o aquecimento do ar é grande, por isso gerando uma ascensão violenta do ar, e os ventos gerados causam estragos na agricultura e nas áreas urbanas. A chuva, quando cai, cai em forma de trombas d'água, compactando o solo. Em decorrência, ali pouca água infiltra e a maior parte escorre, iniciando a erosão e as cheias dos rios. Após algum período, a seca retorna e, como o subsolo não foi abastecido, os cursos d'água não são alimentados (situação essa piorada pela carga de sedimentos carregados pela chuva e depositados em seu leito); e a vegetação não consegue recursos para se desenvolver, isso causando a sua raleação e ocasionando novamente altas temperaturas do ar, ventos fortes e tempestades.

\subsection{Erosão Acelerada}

De acordo com Oliveira (2004), a erosão é um fenômeno geológico normal na modelagem da superfície terrestre, sendo que os agentes externos modificam e transportam o material rochoso num processo lento, de maneira imperceptível, mas de forma permanente.

A apropriação do relevo pelo homem altera o estado natural da vertente, conforme comenta Casseti (2005). Essa alteração é iniciada pelo desmatamento, em razão do qual as modificações das relações processuais são sentidas substancialmente em curto espaço de tempo, ocorrendo mudanças nos processos morfodinâmicos e maior desenvolvimento da morfogênese em detrimento da pedogênese.

Astaras (1984) afirma, em seu estudo, que a remoção e a substituição da vegetação natural são responsáveis, em grande parte, pela ação acelerada de erosão dos solos e que a ação erosiva modifica os perfis das vertentes. $O$ 
autor estudou duas bacias próximas, ao norte da Grécia, sendo que a primeira bacia apresentava processo natural (sem intervenção humana) e a segunda bacia possuía um sistema do tipo processo-resposta (com intervenção humana). Ao comparar as duas bacias, o autor constatou que a infiltração e a remoção de detritos são influenciadas pela ausência de vegetação, pois essa ausência modifica a distribuição de energia e massa, alterando as variáveis morfológicas. A ação erosiva modificou os perfis das vertentes, sendo que, na primeira bacia, apresentou vertentes convexas, onde a evolução das vertentes é mantida pelo recuo paralelo, já que a erosão é quase insignificante, mas, na segunda bacia, as vertentes apresentavam concavidade basal gerada pelo rápido escoamento das águas nas vertentes, pois a erosão é localizada, havendo erosão e deposição.

O principal agente erosivo é a água, porém existe a erosão eólica, que atua também em áreas com vegetação escassa e onde as precipitações são baixas, como afirmam Bertoni e Lombardi Neto (2012, p. 68). Eles afirmam que a erosão é o processo de desprendimento e arraste acelerado das partículas do solo, causadas pela ação da água e pelo vento.

Existem diferentes tipos de erosão, desde os menos perceptíveis até os casos onde são visualmente aparentes no solo, sendo um processo que, aos poucos, os intensifica, tornando-os visíveis.

Bertoni e Lombardi Neto (2012) explicam que os principais tipos de erosão gerados pelo efeito das chuvas são: laminar, em sulcos e voçorocas. A erosão laminar remove apenas a porção superficial do solo, porém é necessária atenção, pois são levadas as partículas leves e pequenas, cuja ausência depois compromete a fertilidade do solo. A erosão em sulcos decorre da irregularidade do solo, onde se formam poças e, dependendo da força e do volume da enxurrada, isso torna os sulcos mais profundos. As voçorocas representam o nível maior de erosão e são geradas a princípio como um sulco, que, ano após ano, foram aprofundados e alargados.

Outro fenômeno que contribui ao escoamento superficial é a compactação do solo, pois diminui a capacidade de infiltração das águas pluviais no solo, favorecendo o início dos processos erosivos. A compactação 
dos solos ocorre devido a alguns fatores, como o uso de máquinas na agricultura, máquinas que, com sua constante movimentação (o mesmo podendo ocorrer com o pisoteio do gado), são responsáveis pela reorganização das partículas do solo, passando a ocupar menos espaço os poros, devido à pressão exercida na superfície, diminuindo o volume do solo (JORGE, 1985).

Os efeitos da compactação para a agricultura não são positivos, pois, em solos compactados, as raízes encontram dificuldades para crescer, resultando em raízes tortuosas, que prejudicarão posteriormente a produção.

Oliveira (2004) assegura que a erosão traz prejuízos, pois, quando é retirada a camada produtiva do solo, resta o subsolo, e este não possui boas condições para o cultivo, pois, geralmente, o subsolo apresenta baixo teor de matéria orgânica e é pouco permeável, permitindo uma maior velocidade das enxurradas. A baixa aptidão para retenção de água exige um arado em profundidade em um solo que já apresenta estrutura fraca, tornando difícil o preparo com a sementeira e, consequentemente, reduzindo a produção. A má estrutura resulta em maior força na tração dos equipamentos agrícolas, causando maiores gastos em combustível.

Os processos erosivos de origem antrópica causam sérios problemas de ordem econômica e ambiental, induzindo à perda de toneladas de solos agricultáveis todos os anos, sendo o uso e a ocupação desordenada um dos principais fatores de causa, e que seriam evitados com algumas práticas de manejo conservacionistas. Há, porém, outros fatores relacionados que originam erosão e merecem melhor entendimento.

\subsection{Estudo da Erosão em Bacia Hidrográfica com Aplicação de Modelos de Perdas de Solos (EUPS)}

Existem modelos matemáticos e estatísticos que permitem estimar a perda de solos, além de simular cenários e de indicar as classes de capacidade do uso agrícola em bacias hidrográficas, conforme demonstrado por Pinto e Garcia (2005). 
A USLE ou EUPS (Equação Universal de Perda de Solos) é um modelo que permite prever a média anual de perda de solos por erosão laminar em condições específicas (WISCHMEIER e SMITH, 1978), sendo possível determinar o cultivo e alternativas de gestão a fim de reduzir a perda para cada tipo de solo (MITCHELL e BUBENZER, 1980).

A EUPS leva em consideração o tipo de solo, a topografia, o potencial erosivo da chuva, o uso e a ocupação do solo e as práticas conservacionistas empregadas. É resultado de vários estudos que foram, ao longo dos anos, aprimorados, sendo, no final da década de 1950, aprovada com estudos de perdas de solo e de água em diferentes locais dos Estados Unidos (WISCHMEIER e SMITH, 1978; BERTONI e LOMBARDI NETO, 2012).

A fórmula para aplicação da equação está representada abaixo:

$$
\text { A= R. K. L. S. C. P }
$$

Onde:

$A=$ estimativa de perda de solo por unidade de área (t/ha.ano);

$\mathrm{R}=$ fator erosividade da chuva (MJ.mm/ha.h.ano);

$\mathrm{K}=$ fator erodibilidade do solo (t.ha.h/ha.MJ.mm);

$L$ e $S=$ fator variáveis fisiográficas do terreno, consideram a extensão da vertente (em metros) e da declividade (em \%) (adimensional);

$\mathrm{C}=$ fator de uso e manejo (adimensional),

$\mathrm{P}=$ fator práticas conservacionistas (adimensional).

As melhorias na equação estão relacionadas ao que segue: (i) 0 índice de erosão da chuva; (ii) um método de avaliar os manejos de uma cultura, por meio das características climáticas locais; (iii) um fator quantitativo de erodibilidade do solo: e (iv) um método que considera as ocorrências de certas variáveis, como o nível de produtividade, sequência de culturas e manejo de resíduos (BERTONI e LOMBARDI NETO, 2012). 
Devido às mudanças aplicadas na equação de perda de solos, essa mesma equação passou a possuir caráter de aplicação generalizada, pois não apresenta restrições climáticas, nem geográficas (BERTONI e LOMBARDI NETO, 2012).

Apesar das melhorias apresentadas pelos novos estudos, a equação apresenta algumas limitações para estudos em bacias hidrográficas, pois a equação apresenta índices de perdas de solos maiores que a realidade, já que considera como sendo perdas solos em que estão depositados em áreas mais planas, como em fundos de vale (AMORIM, DA SILVA; PRUSKI, 2009). Fernandez (1996) também salienta outro problema ao utilizar a EUPS em bacias hidrográficas. Trata-se do problema do fator topográfico, pois os estudos com a EUPS se limitam a vertentes com no máximo $300 \mathrm{~m}$ de comprimento e algo em torno de $20 \%$ de declividade, valores sendo extrapolados comumente em uma bacia.

O autor ainda comenta sobre a necessidade de se mapear os fatores antrópicos em campo, ou seja, não são suficientes apenas os dados de sensoriamento remoto, visto que as mudanças nas rotações de culturas são muito aceleradas. Ainda nesse sentido, Pinto e Garcia (2005) afirmam que é essencial comparar os resultados obtidos por meio da EUPS em campo, pois o modelo oferece apenas uma aproximação dos valores reais.

Sobre a aplicabilidade da EUPS, Bertoni e Lombardi Neto (2012) destacam que esse método representa um instrumento de grande valia para trabalhos de conservação do solo, podendo predizer, com bastante exatidão, as condições de perdas anuais médias de acordo com o declive do terreno, tipos de solos, sistema de manejo e cultivos.

Stein, Ponçano e Saad (2003) aplicaram a EUPS na Bacia do Rio Santo Anastácio, localizada no oeste paulista, região que apresenta graves problemas relacionados aos processos erosivos. A EUPS foi utilizada para determinar os processos erosivos laminares, atribuindo valores absolutos para os diferentes fatores da equação. Os autores ainda avaliaram as boçorocas e ravinas utilizando mapas temáticos de geologia, geomorfologia e pedologia, estabelecendo correlações para a identificação de compartimentos 
relativamente homogêneos da paisagem e que possuem diferentes susceptibilidades erosivas naturais. Os dois resultados foram confrontados gerando um mapa com as subdivisões dos setores da paisagem com riscos atuais de erosão diferenciados.

Ponçano e Christofoletti (1987) desenvolveram um estudo que estima a erosão pluvial em regiões tropicais utilizando a EUPS para a compreensão dos processos erosivos em solos lateríticos, isso em vista da necessidade de adaptação da equação para cada região onde se pretenda aplicá-la.

Para desenvolvimento dos estudos da EUPS, a aplicação do sensoriamento remoto e do geoprocessamento é uma excelente maneira de aquisição, armazenamento e manipulação de dados, permitindo cruzar vários elementos do sistema. Para a avaliação de bacias hidrográficas, o uso dessas tecnologias auxilia os estudos de manejo do solo e da água (PINTO E GARCIA, 2005).

Rosa (2001) utilizou técnicas de sensoriamento remoto para estudos de erosão laminar potencial nas microbacias do Córrego dos Peixes e Córrego Buriti dos Bois, no município de Prata, em Goiás, com o intuito de demonstrar a aplicação da EUPS em grandes áreas. Os resultados demonstraram que a perda de solos na região estudada é de menos de 12 t/ha.ano em $51,1 \%$ da área, e maior de 12 t/ha.ano em $48,9 \%$ da área das microbacias, ou seja, em quase metade das microbacias há maior taxa de erosão do que formação dos solos de acordo a tolerância à erosão dos solos do estado de São Paulo (BERTONI e LOMBARDI NETO, 2012).

Pinto e Garcia (2005) dizem que, para entender os processos erosivos, outros fatores devem ser analisados em conjunto, como a geometria das vertentes (declividade, extensão e arquitetura do perfil), a litologia, a cobertura pedológica, dados pluviométricos, a cobertura vegetal natural e antrópica, além de outros fatores que permitam identificar os desencadeadores dos processos erosivos. Tais fatores de interferência podem ser obtidos, cruzados e analisados de maneira integrada, por meio de produtos de sensoriamento remoto. 
De acordo com Corrêa (2011), o sensoriamento remoto é uma ferramenta para os estudos de processos erosivos de grande importância, pois permite caracterizar e avaliar a dinâmica do uso do solo e dos índices de vegetação, que, aliados a outros documentos, possibilita fornecer subsídios a tais análises.

Florenzano (2002) afirma que, em áreas rurais, por exemplo, o uso de sensoriamento e geoprocessamento permite identificar o tipo de uso, calcular as áreas ocupadas com cada tipo de uso, possibilitando obter uma estimativa da produção agrícola, além de ser possível acompanhar multitemporalmente a evolução dos ambientes. Rosa (1990) empregou esse recurso ao utilizar imagens de satélite Landsat TM para estudos de uso e ocupação do solo, resultando satisfatoriamente na identificação das categorias existentes em sua área de estudo, em Uberlândia, em Minas Gerais.

De maneira geral, é possível afirmar que o sensoriamento remoto e o geoprocessamento são técnicas que permitem desenvolver melhorias e maiores facilidades para aplicação da EUPS, além de possibilitar seu uso em diversas escalas, desde que haja subsídios para tal. Os SIGs permitem que sejam desenvolvidos individualmente os fatores da EUPS para posterior integração dos resultados, possibilitando que sejam identificados os locais mais críticos e sujeitos aos processos erosivos, para que sejam desenvolvidas medidas mitigatórias.

\subsubsection{Fator R: Potencial erosivo das chuvas}

A ação da chuva gera erosão a partir do aumento das precipitações totais anuais (TAVARES, 1986) e, dependendo dos picos de intensidade da chuva, haverá maior escoamento superficial e, consequentemente, deposição de sedimentos (WISCHMEIER e SMITH, 1978).

De acordo com Lombardi Neto e Moldenhauer (1992), o índice de erosividade é uma avalição numérica de um valor médio anual de chuva de um 
determinado local, o qual vai predizer a capacidade que essa chuva terá de erodir o solo.

Analisando as características das chuvas, deve-se levar em consideração a intensidade da chuva e a energia cinética que o impacto da gota da chuva produz no solo em determinado tempo, levando a conhecer o potencial erosivo da chuva, potencial esse dado pela relação do valor El30 (índice de erosão) (BERTONI e LOMBARDI NETO, 2012).

O valor do El30 é dado pela fórmula:

$$
\mathrm{El}_{30}=\mathrm{Ec} \times \mathrm{I}_{30}
$$

Onde:

El30= índice de erosividade (MJ/ha);

$\mathrm{Ec}=$ energia cinética da chuva $(\mathrm{MJ} / \mathrm{ha})$,

130 = intensidade máxima em $30 \mathrm{~min},(\mathrm{~mm} / \mathrm{h})$.

Para se obter a energia cinética da chuva, é realizada a seguinte equação:

$$
E c=0,119+0,0873 \log I
$$

Onde:

$\mathrm{Ec}=$ energia cinética em $\mathrm{MJ} / \mathrm{ha} \cdot \mathrm{mm}$;

I= intensidade da chuva em $\mathrm{mm} / \mathrm{h}$.

Há, porém, certa dificuldade de conseguir registros de pluviógrafos ou, mesmo quando há registros, a análise dos diagramas da energia cinética é morosa e trabalhosa (BERTONI e LOMBARDI NETO, 2012). 
A alternativa para esse impasse é a utilização de fatores climáticos, ou seja, relacionando a precipitação média mensal e a precipitação média anual, (LOMBARDI NETO e MOLDENHAUER, 1992), conforme trabalhos de Tavares (1986), Stein et al. (1987), Amorim (2010) e Côrrea (2011).

Lombardi Neto e Moldenhauer (1992) desenvolveram uma equação para Campinas. A equação deles envolve a regressão entre o índice médio mensal de erosividade e o coeficiente de chuva, obtendo alta correlação $\left(r^{2}=0,983\right)$ :

$$
\mathrm{EI} 30=68,730\left(\mathrm{p}^{2} / \mathrm{P}\right)^{0,841}
$$

Onde:

El30= Índice de erosividade médio mensal para chuvas (MJ.mm/ha.h);

$\mathrm{p}=$ precipitação média mensal $(\mathrm{em} \mathrm{mm})$,

$\mathrm{P}=$ precipitação média anual (em $\mathrm{mm})$.

O coeficiente de chuva é determinado pela proposta de Fournier (1960 apud KURATANI, 2001):

$$
\mathrm{Cc}=\mathrm{p}^{2} / \mathrm{P}
$$

Onde:

$\mathrm{Cc}=$ coeficiente de chuva $(\mathrm{mm})$;

$\mathrm{p}=$ precipitação média mensal $(\mathrm{mm})$;

$\mathrm{P}=$ precipitação média anual $(\mathrm{mm})$.

De acordo com Bertoni e Lombardi Neto (2012), o índice de erosividade (fator R) estima, com relativa precisão, os valores de El30 de um local para um período de 20 anos ou mais com totais de chuva. 
Kuratani (2001) mostrou ser possível utilizar a equação de determinado lugar, desde que haja uma série pluviométrica igual e distribuição de chuvas semelhante ao local comparado, ao estudar a erosividade de Mirandópolis/SP pela equação de Coelho (2001) para Votuporanga (SP).

$$
E I 30=-0,8804 \cdot R c^{2}+65,4290 \cdot R c+62,9790 \quad r=0,9855(p<0,01)
$$

Kuratani (2001) comparou os valores médios de precipitações mensais no período entre 1976 e 2000, com os valores de Votuporanga (COELHO, 2001), observando que a equação poderia ser utilizada para Mirandópolis, já que houve boa sobreposição sobre os intervalos de confiança para os dados mensais das duas localidades.

O valor obtido para Mirandópolis foi de $6962 \mathrm{MJ} . \mathrm{mm} / \mathrm{ha}$.h.ano, sendo que a cada 2,33 anos e probabilidade de $43,5 \%$, o evento possa se repetir. Para os períodos de retorno de 2, 5, 10, 20, 50 e 100 anos, esperam-se valores de 6803, 7654, 8217, 8756, 9455 e 9979 MJ.mm/ha.h.ano, respectivamente.

Santos (2006) também utilizou a equação de outro local, no caso, Piraju/SP, de Roque et al. (2001) para calcular a erosividade em Maringá/PR:

$$
\mathrm{EI} 30=72,5488 \mathrm{Rc}^{0,8488} \quad(\mathrm{r}=0,9629)
$$

$\mathrm{Na}$ cidade de Maringá/PR, foi alcançado o índice de 8536 MJ.mm/ha.h.ano, onde o período de outubro a março era o de maior concentração desse valor, e o mês de janeiro apresentou o maior índice de erosividade (1350 MJ mm ha ${ }^{-1} \mathrm{~h}^{-1}$ ano-1 $^{-1}$ ) (SANTOS, 2006).

O índice médio anual de erosividade (EI30) para Piraju/SP, calculado por Roque et al. (2001), é de 7.074 MJ.mm/ha.h.ano durante o período de 1975 a 1997, esperando que o índice ocorra no local pelo menos uma vez a cada 2,33 anos, com uma probabilidade de $42,92 \%$. 
Colodro (1999) obteve alto índice de correlação entre os valores de El30 e os coeficientes de chuva para Teodoro Sampaio/SP, para o período de 1977 a 1994, cujo resultado de erosividade é esperado pelo menos uma vez a cada 2,33 anos, com uma probabilidade de ocorrência de 42,9\%. A equação estimada por Colodro (1999) é a seguinte:

$$
\mathrm{EI} 30=106,8183+46,9562 \mathrm{Rc} \quad(\mathrm{r}=0,963)
$$

O período de outubro a março foi o que apresentou maior índice de ocorrência de erosão nos trabalhos de Roque et al. (2001), Santos (2006), Kuratani (2001), Colodro (1999), em Piraju/SP, Maringá/PR, Mirandópolis/SP e Teodoro Sampaio/SP, respectivamente.

Stein et al. (1987) obtiveram altos índices de erosividade da Bacia do Peixe-Paranapanema, localizada a oeste do estado de São Paulo, nas áreas das Cuestas Basálticas, talvez pela topografia apresentada, além de dois pontos concentrados, e os valores mais baixos são da Depressão Periférica, voltando a aumentar no Planalto Atlântico.

Apesar das dificuldades de se obter o fator de erosividade da chuva, isso devido à escassa fonte de dados alcançada por pluviógrafos em determinadas localidades, há possibilidades de utilizar dados de pluviosidade mensal e anual e adequar as equações desenvolvidas em locais próximos à área de estudo.

Os dados de precipitação são importantes para analisar os períodos de maior pluviosidade, já que existe relação direta com a perda de solos por erosão, permitindo que haja planos de controle na minimização das perdas nos períodos mais críticos, assim como o planejamento dos ciclos de cultivo das culturas agrícolas para cada região.

\subsubsection{Fator K: Erodibilidade}


A erodibilidade é definida pelas diferentes características físicas dos solos (velocidade da infiltração, permeabilidade e capacidade total de armazenamento de água) e pela resistência à força de dispersão, abrasão e transporte pela chuva e escoamento (BERTONI e LOMBARDI NETO, 2012). Isso vale dizer que a erodibilidade consiste na susceptibilidade natural que 0 solo possui à erosão diante das propriedades inerentes do solo (STEIN et al., 1987).

De acordo com Stein, Ponçano e Saad (2003), a erodibilidade dos solos é um fator que pode indicar diferentes condições para cada tipo de processo erosivo. Assim, por exemplo, um horizonte superficial com boa permeabilidade remete a solos com perfis homogêneos, profundos e textura mais grossa, ou seja, um solo com baixas condições à erosão laminar. Ocorre, porém, que essas mesmas características podem favorecer a erosão linear por fluxos concentrados devido à desagregação pelo impacto das gotas da chuva e ao atrito por abrasão das enxurradas.

Algumas características dos solos, como a diminuição do teor de silte, tornam o solo menos erodível, assim como ao contrário; quando o teor de matéria orgânica é baixo, o solo é então facilmente erodido, pois apresenta pouca resistência ao impacto das gotas da chuva por não possuir partículas agregadoras típicas da matéria orgânica (WISCHMEIER e SMITH, 1978 e TAVARES, 1986).

A matéria orgânica melhora a porosidade e a retenção de água no solo, agindo como uma espoja, além de servir como cimento na formação de grânulos do solo e servir de fonte de minerais às culturas (JORGE, 1983). A fração silte no solo determina maior tendência ao encrostamento, causada quando a ação da água, e dos ciclos de umedecimento e secagem, alteram a estrutura superficial do solo, causando a reorganização das partículas e levando à formação de uma camada que dificulta a infiltração (RESENDE et al., 1999).

Para o cálculo do fator R, Wischmeier e Smith (1978) elaboraram um nomograma cuja aplicabilidade é ampla, sendo possível mensurar, de forma 
gráfica, o fator de erodibilidade a partir de algumas características do solo, sendo elas:

1) porcentagem de matéria orgânica;

2) porcentagem de silte mais areia muito fina, entre 0,002 $-0,10 \mathrm{~mm}$;

3) porcentagem de areia, compreendida entre 0,10 e 2,0 mm;

4) classes de permeabilidade $e$

5) tipo de estrutura.

Fernández e Santos (1980) determinaram o fator K para três solos do estado da Paraíba, utilizando o nomograma proposto por Wischmeier e Smith (1978), chegando ao resultado de $K=0,010$ para os solos Terra Roxa Estruturada (Nitossolos) e Podzólico Vermelho-Amarelo (Argissolo) no município de Areia e o valor K de 0,014 para o Podzólico Vermelho-Amarelo do município de Alagoa Nova. Os autores chegaram à conclusão de que as relações de tamanho de partículas são os principais fatores que determinam o nível de erosão do solo, como no Podzólico Vermelho-Amarelo do município de Alagoa Nova, que apresentou resultado de $\mathrm{K}$ maior (menor resistência à erosão) se comparado aos outros dois solos, isso sendo devido a maiores níveis de silte+areia muito fina e areia com tamanho entre 1,0 e 2,0 mm presentes.

Mesmo assim, porém, de acordo com Amorim et al. (2009), o nomograma não apresenta bons resultados quando aplicado aos solos tropicais, o que é devido às diferenças texturais, principalmente para os latossolos brasileiros, como constatado por Oliveira e Bahia (1984) e Lima et al. (2007).

De acordo com Espindola (2013) o cálculo de erodibilidade de Wischmeier e Smith (1978) é comprometido devido ao usual (falso) conteúdo de silte nos latossolos brasileiros.

Lima et al. (2007) compararam os métodos para o valor de K. Além do nomograma, estão os métodos propostos por Dernadin (1990); por Van der Knijff et al. (1999) e por Stone Hillborn (2002). Dessa comparação concluíram que os resultados obtidos pelo nomograma foram os mais baixos, e o de 
Denardin (1990) apresentou resultado mais próximo a um valor de K local, usado como referência pelos autores para Latossolos.

Silva et al. (2000) testaram 23 modelos indiretos para estimativa do fator K para Latossolos dos estados de Rio Grande do Sul, de Santa Catarina, do Paraná, de São Paulo, de Minas Gerais, de Goiás, do Ceará, do Distrito Federal, da Paraíba, do Amazonas e do Pará, e chegaram à conclusão de que nenhum método testado é recomendável para estimativa da erodibilidade para os Latossolos, sugerindo o desenvolvimento de estudos para o grupo de Latossolos.

Estudando os solos do estado de São Paulo, Bertoni e Lobardi Neto (2012) consideraram a argila natural, a argila dispersa e a umidade equivalente dos horizontes $A$ e $B$ de solos com $B$ textural e $B$ latossólico. Os resultados da relação de erosão (razão entre relação de dispersão e a relação argila dispersa/umidade equivalente) mostraram que os solos com $B$ textural (argissolos) são mais erodíveis (BERTONI E LOBARDI NETO, 2012; FREIRE, PESSOTTI, 1974).

Mannigel et al. (2002) constataram que, quanto maior a relação textural do solo, menor é a tolerância e maior a erodibilidade dos solos. Essa foi também a conclusão de Freire e Pessotti (1974) para os argissolos (antigos solos podzolizados) ao afirmar que a erodibilidade desses solos é maior quanto maior é o gradiente textural entre os horizontes A e B. Mannigel et al. (2002) determinaram o fator $\mathrm{K}$ e a tolerância de perdas de 25 perfis representativos dos solos do estado de São Paulo, baseados no Sistema Brasileiro de Classificação dos Solos (EMBRAPA, 2006). A relação textural foi obtida pela relação entre a distribuição média percentual de argila do sub-horizonte $B$ pela distribuição média percentual de argila do sub-horizonte A. A tolerância de perda do solo foi baseada na metodologia de Stamey (1964), citada por Wischmeier e Smith (1965) e por Lombardi Neto e Bertoni (1975), adaptando-a em relação à profundidade do solo, à relação textural e à quantidade de terra por unidade de superfície.

Arraes et al. (2010) analisaram a erodibilidade dos solos da Microbacia do Córrego do Tijuco/SP, cujos solos são Argissolos Vermelho-Amarelos 
eutróficos e Latossolos Vermelhos Distróficos e concluíram que ambos apresentam alta erodibilidade (maiores que 0,040 t.ha.h/ha.MJ.mm), já que os Argissolos possuem abrupta diferença textural, o que facilita o saturação do horizonte superior. Já os Latossolos com textura média apresentam escoamento superficial concentrado da água das chuvas e, quando em condições de ocupação inadequada, facilitam os processos erosivos.

Diante das características naturais e da erosão acelerada por ação antrópica, o conceito de tolerância de perda dos solos é utilizado para manter a capacidade produtiva de um solo, estimando a quantidade máxima de solo que pode ser perdida por erosão. Se respeitado esse valor, as características naturais, a fertilidade e a produtividade agrícola serão mantidas (CARVALHO, 2012).

O conhecimento da morfologia dos tipos de solos, principalmente as propriedades intrínsecas que determinam maior ou menor vulnerabilidade à erosão, representa um importante atributo da EUPS, porém o assunto merece informações e entendimentos mais avançados, principalmente em relação aos solos que possuem maior teor de argila.

\subsubsection{Fator LS: Fator Topográfico}

Para o entendimento e a quantificação da erosão, é de fundamental importância o conhecimento das formas e das características do relevo, pois exerce influência no escoamento das águas e age como potencializador da erosão hídrica. A declividade e o comprimento da vertente caracterizam-se como principais elementos significativos nos processos erosivos (LIMA, 2003; SOUZA et al., 2003).

Os processos erosivos são influenciados pelo grau de declive, pois é a declividade que controla a velocidade da enxurrada e, consequentemente, o volume de sedimentos removido, enquanto que o comprimento de rampa leva ao aumento de volume e da velocidade de acordo com a extensão percorrida (LIMA, 2003). 
Mesmo assim, porém, quanto maior o comprimento de rampa maior é a possibilidade de infiltração ou de evaporação da água, sendo, assim, a quantidade de água decresce com o aumento do comprimento da rampa, necessitando de maiores estudos do valor absoluto escoado (TAVARES, 1986).

O fator topográfico é a combinação do fator comprimento de declive e do fator declividade. O fator comprimento de declive (L) na EUPS representa a relação de perda de solos entre um comprimento de declive qualquer e outro comprimento de declive de $25 \mathrm{~m}$, ambos sob mesmo solo e grau de declive; o grau de declive (S) é a relação de perda de solos entre um declive qualquer e um declive de $9 \%$, também sob mesmo solo e mesmo comprimento de rampa (BERTONI e LOMBARDI NETO, 2012).

A topografia provoca diferentes processos erosivos, dadas as suas características, ou seja, a declividade e o comprimento de rampa são os fatores que controlam o escoamento das águas nas encostas, incidindo a erosão laminar pelo declive. Os processos de erosão linear também ocorrem quando o comprimento de rampa e ondulações das vertentes coletoras de fluxos concentra e aumenta o escoamento pluvial (STEIN, PONÇANO e SAAD, 2003).

O cálculo abaixo possibilita obter o fator topográfico (BERTONI e LOMBARDI NETO, 2012):

$$
L S=0,00984 C^{0,63} D^{1,18}
$$

Onde:

LS= Fator topográfico

$\mathrm{C}=$ Comprimento de rampa em metros

$D=$ Grau de declive em porcentagem 
Wischmeier e Smith (1978) definem o comprimento de rampa como a distância entre o ponto de origem do fluxo de água até o ponto em que a declividade diminui o suficiente para se iniciar a deposição de sedimentos ou o local em que se concentra o escoamento num canal de drenagem definido.

Tomazoni e Guimarães (2005) obtiveram o fator topográfico no SIG Spring traçando manualmente os divisores de água principais e secundários, atribuindo-Ihes valor de 0 , pois, segundo os autores, o caminho percorrido pelas águas inicia-se no divisor de água e vai até o rio. O método utilizado por Tomazoni e Guimarães (2005), para determinação do fator LS, considerou apenas a encosta natural, desprezando a quebra da circulação da água por barreiras, como mata ou práticas conservacionistas mecânicas.

Ruthes (2012) também utilizou esse método em um SIG, ao aplicar a ferramenta chamada mapa de distância para determinar o comprimento médio de rampa de uma bacia hidrográfica, delimitando seus interflúvios e a rede de drenagem.

O comprimento médio das vertentes também pode ser considerado como a extensão do percurso superficial, ou seja, a extensão percorrida pelo escoamento pluvial. Tal recurso foi utilizado por Costa (2005), que utilizou o Spring para obter o resultado de comprimento de rampa, e Tavares (1986), que mediu manualmente com o auxílio do curvímetro.

Para a obtenção do fator topográfico, Minella et al. (2010) compararam os resultados de dois métodos de representação espacial entre si na escala de bacias hidrográficas e utilizaram o método tradicional, com análise no campo para o fator LS. Os métodos em representação espacial foram os propostos por Desmet e Govers (1996) e por Moore e Burch (1986a), sendo necessária a definição da área de fluxo acumulada e a área de contribuição específica, respectivamente. O terceiro método, em campo, foi realizado a partir dos comprimentos de rampa e declividade em transectos em cada sub-bacia. Comparando os dois métodos de representação espacial, os resultados se mostraram parecidos, diferentemente dos valores encontrados em campo, indicando que o uso de métodos de representação espacial para o fator LS é 
de maior valia na escala de bacias hidrográficas, mesmo em áreas de relevo complexo.

Valeriano (2002) encontrou dificuldades para estabelecer o limite de curvatura e confluência no movimento das águas superficiais com dados cartográficos, sendo que, em alguns casos, o resultado é susceptível a alguma subjetividade. O autor utilizou metodologias estatísticas e geoestatísticas do comprimento de rampa, com dados cartográficos manuais e dados de campo. Os resultados obtidos com as técnicas digitais foram satisfatórios, desde que haja detalhamento cartográfico e reconhecimento das feições topográficas, mostrando melhores resultados em áreas com terrenos suaves.

O comprimento de rampa é um fator de certa complexidade devido aos diferentes perfis do relevo, podendo ser reto, côncavo, convexo ou uma combinação de formatos (FUJIHARA, 2002).

Wilson (1986) afirma que a aplicação dos fatores LS da EUPS em bacias hidrográficas gera problemas, já que é necessária a mensuração de vários perfis, exigindo tempo e sendo mais custoso. O autor afirma também que a média dos valores de LS em bacias hidrográficas não pode ser utilizada para se estimar a média de perda de solos na bacia, porque o comprimento de rampa e o de declive são fatores não lineares, e não distribuídos de maneira uniforme. Outra dificuldade é que os valores de $\mathrm{K}$ e $\mathrm{C}$ podem não ser uniformes em relação aos fatores $L$ e $S$ em bacias hidrográficas, ou seja, se as encostas íngremes não forem erodíveis em relação ao uso e ocupação, o fator $C$ irá superestimar a perda de solos para a bacia. Também em valores de $\mathrm{K}$, que podem variar de acordo com a declividade ao longo dos perfis.

O método utilizado por Wilson (1986) foi aplicado em 30 perfis na Bacia Hidrográfica de Ontario's Lovers Creek, para medir o comprimento de rampa, forma e declividade, utilizando análise estatística para dividir os perfis em segmentos, de acordo com a metodologia de Young (1971); utilizando também o método de Foster e Wischmeier (1974), mediram-se os valores de LS para encostas irregulares e, por meio da distribuição da frequência acumulados valores de LS para bacias, foram computados, por ponderação, os valores de perfil de acordo com o respectivo comprimento. 
Como visto, o fator topográfico regula a intensidade das águas das chuvas nas encostas, variando de acordo com a declividade e o comprimento das rampas. E, devido às diversas formas do relevo, certas dificuldades se apresentam para a obtenção de tal fator. Mesmo assim, entretanto, o uso de ferramentas e de dados digitais permite a análise da superfície do terreno de forma regular, considerando a dificuldade de se trabalhar com escala real, como no caso de bacias hidrográficas, que é uma unidade de dimensões territoriais.

2.3.4 Fator C: Uso e manejo dos solos e Fator P: Práticas conservacionistas

O uso correto do solo tem importante influência positiva no escoamento superficial das águas e na deposição de sedimentos nos rios, pois oferece uma barreira para a remoção das partículas de solo, diminuindo a energia e o impacto gerado pelas gotas de chuva, além de minimizar a velocidade da água ao longo do escoamento nas vertentes e de proteger o solo da compactação. $O$ uso desordenado e a ausência de práticas adequadas, ao contrário, aumentam tanto a compactação do solo quanto o carreamento de sedimentos para as porções mais baixas do relevo, resultando no assoreamento dos canais.

O uso e manejo dos solos atinge todas as ocupações existentes, seja a utilização antrópica de uso rural, sejam as ocupações naturais, como as vegetações nativas e os corpos d'água. Esses elementos da paisagem indicam diferentes suscetibilidades erosivas naturais e riscos atuais de erosão, sendo avaliadas as perdas de solos provenientes das práticas de conservação e de manejo (STEIN, PONÇANO e SAAD, 2003).

A melhor maneira de se evitar ou de amenizar processos erosivos já iniciados é implantar práticas conservacionistas e técnicas de manejo que melhor sejam adequadas às necessidades do produtor rural e da área, a fim de que a relação de ambos seja sustentável, ou seja, que a terra garanta a produção agrícola do produtor rural, porém sem exaurir o solo que lhe sustenta as atividades agrícolas. 
Para estudos de erosão, o uso e as práticas conservacionistas são tratados em conjunto (CP), não podendo analisá-las individualmente, (WISCHMEIER e STEIN, 1978; STEIN et al., 1987; TAVARES, 1986), pois a interação da influência dos dois fatores representa a perda de solos devidos ao fator uso-manejo (CP) (STEIN et al., 1987).

O fator $C$ pode ser entendido como a relação esperada de perda de solos de um terreno cultivado em dadas condições e as perdas de um terreno mantido continuamente descoberto e cultivado. $\mathrm{O}$ fator $\mathrm{P}$ e a relação de perda de solo em um terreno cultivado com determinada prática conservacionista e outro terreno cultivado no sentido do declive (morro abaixo) (WISCHMEIER e STEIN, 1978; STEIN et al., 1987; BERTONI e LOMBARDI NETO, 2012).

A Razão de Perda de Solos (RPS) é a relação entre a perda de solos entre um terreno cultivado (parcela de trabalho) e em um terreno mantido em alqueive (parcela-padrão), ou seja, a RPS é calculada por meio de sistemas coletores em pesquisas experimentais de parcelas de $25 \mathrm{~m}$ de comprimento, no sentido do declive, e $4 \mathrm{~m}$ de largura, com declive de $9 \%$. A parcela-padrão é mantida descoberta, porém recebe mensalmente uma aração e uma gradagem sentido morro abaixo, enquanto a parcela de trabalho, que possui as mesmas características de tamanho e declividade, é cultivada com manejo e práticas conservacionistas (CARVALHO, 2012).

Segundo Bertoni e Lombardi Neto (2012), para a obtenção do Fator C é necessária a combinação com os valores do índice de erosão (EI) anual, pois o controle da erosão nos sistemas de plantio em um determinado local depende, em parte, de como as chuvas erosivas anuais estão distribuídas ao longo dos estágios de manejo das culturas (WISCHMEIER e SMITH, 1978). A Tabela 1 representa os períodos de desenvolvimento para cada estágio da cultura. 
Tabela 1 - Estágios de desenvolvimento da cultura para a composição do Fator C.

\begin{tabular}{|c|c|c|}
\hline Período & Operação & Cronologia \\
\hline D & Preparo do solo & $\begin{array}{c}\text { Do início do preparo até o início } \\
\text { do plantio }\end{array}$ \\
\hline 1 & Plantio & $\begin{array}{c}\text { Do início do plantio até um mês } \\
\text { após }\end{array}$ \\
\hline 2 & Estabelecimento & $\begin{array}{c}\text { Do fim do período } 1 \text { até } 2 \text { meses } \\
\text { após o plantio }\end{array}$ \\
\hline 3 & $\begin{array}{l}\text { Crescimento e } \\
\text { Maturação }\end{array}$ & $\begin{array}{c}\text { De dois meses após o plantio até } \\
\text { a colheita }\end{array}$ \\
\hline 4 & Resíduo & $\begin{array}{c}\text { Da colheita até o início do novo } \\
\text { preparo do solo }\end{array}$ \\
\hline
\end{tabular}

Fonte: Bertoni e Lombardi Neto (2012).

As técnicas de manejo e conservação dos solos, ou seja, técnicas ou práticas que aumentam a resistência do solo frente aos processos erosivos, podem ser denominadas de vegetativas, edáficas e mecânicas (BERTONI e LOMBARDI NETO, 2012).

No caso das práticas vegetativas, elas se consistem em utilizar vegetação como barreira à erosão, seja erosão de origem eólica ou erosão das águas, sendo barreira de florestamento ou de reflorestamento, pastagem, plantas de cobertura, cultura em faixas, cordões de vegetação permanente, alternância de capinas, cobertura morta, faixas de bordaduras e quebra-ventos. No caso das práticas de caráter edáfico, trata-se de atividades que melhoram a fertilidade do solo e diminuem os processos erosivos, já que aumentam a camada orgânica e superficial do solo por meio de mudanças no sistema de cultivo, sendo mudanças de controle do fogo, de adubação verde, de adubação química, de adubação orgânica e de calagem. Por fim, no caso das práticas mecânicas, consistem em técnicas de maior custo, em termos econômicos, pois será necessário construir obras artificiais para conter os processos erosivos, obras tais como distribuição racional dos caminhos, plantio em contorno, terraceamento, sulcos e camalhões em pastagem, além de canais escoadouros (BERTONI e LOMBARDI NETO, 2012).

Bellinazzi Júnior, Bertolini e Lombardi Neto (1981) afirmam que a prática mais eficiente no controle de perda de solos por erosão em áreas agricultáveis 
é o terraceamento, sendo bastante difundido no estado de São Paulo, e aplicado em grande escala desde aproximadamente a década de 1950.

A prática de terraceamento apresentou menor perda de solo por erosão em relação a lavouras não terraceadas, que possuíam apenas a prática de curvas de nível. Isso é demonstrado pelos resultados do trabalho apresentado por Demarchi (2012), que explica que os terraços reduzem a velocidade do escoamento superficial e promovem a deposição dos sedimentos e a infiltração da água no solo, pois a vertente é segmentada.

Para identificação do uso do solo e práticas de manejo, os produtos do sensoriamento remoto, como imagens de satélite e fotografias aéreas, oferecem maior facilidade de interpretação, que, dependendo da sua resolução, possibilita o reconhecimento de um maior número de classes de uso e ocupação, como salienta o trabalho de Vasquez-Fernandez et al. (1996), trabalho em que foram utilizadas fotografias aéreas na escala de 1:38.000 para a discriminação das classes de uso do solo em uma bacia hidrográfica. Os autores encontraram 46 classes de uso com fotografias aéreas, em detrimento de outros autores, que utilizaram imagens orbitais multiespectrais e reconheceram apenas 6 classes de uso (FERNANDEZ et al.,1996).

Para maior detalhamento das classes do Fator C, Fernandez et al. (1996) sugerem, como alternativa, a correlação de imagens multiespectrais com dados de reflectância com índices de cobertura vegetal, como em trabalhos realizados por Corrêa (2011) e por Feitosa (2006).

Stein et al. (1987) utilizaram imagens Landsat TM para definir as categorias dos Fatores C e P, na Bacia dos Rios Peixe-Paranapanema/SP, atribuindo valores para cada categoria de uso e ocupação definidos por meio de técnicas de uso e de manejo e de práticas conservacionistas. Mediante imagens Landsat TM bandas 3 e 4, os autores obtiveram o uso e ocupação das terras e potencial natural de erosão laminar durante o período de cultivo das culturas temporárias no período seco de 1985. Devido à resolução das imagens de satélite Landsat TM, os resultados, por vezes, foram generalizados, homogêneos, impossibilitando uma interpretação mais adequada dos processos erosivos (STEIN et al., 1987). 
Feitosa (2006) utilizou o Índice de Vegetação por Diferença Normalizada (NDVI) junto a imagens de satélite CCD/CBERS-2 e obteve nível de detalhamento satisfatório para observar as mudanças sazonais na vegetação. Assim também procedeu Corrêa (2011).

Para a análise de fotointerpretação das unidades de mapeamento em sua área de estudo, Miguel (2010) aproveitou as imagens Quick Bird disponibilizadas pelo aplicativo Google Earth, mostrando serem satisfatórias e confiáveis.

Para identificar as classes de uso e ocupação da Bacia do Rio Campinas, em Joinville/SC, Guimarães et al. (2011) utilizaram imagens aerofotogramétricas de junho de 2003, e imagem de satélite Landsat ETM, bandas 5, 4, 3, 2 e 1, de setembro de 2005. Encontraram-se baixos valores de perda de solos por erosão, pois $70,5 \%$ da área da microbacia apresentou valores de perda entre 0 a 1 ton. $h a^{-1} \cdot a n o^{-1}$ devido às práticas conservacionistas, que, no caso da microbacia, possui florestas nativas conservadas $(70,3 \%)$.

A aplicação de modelos preditivos de erosão junto ao uso de geotecnologias como os SIGs permite simular cenários alternativos (ROO, HAZELHOFF e BURROUGH, 1989), possibilitando a indicação de melhor manejo em bacias hidrográficas, como estudado por Machado, Vettorazzi e Xavier (2003), que simularam dois cenários no SIG Arc View por dois anos, utilizando o modelo SWAT (Soil and Water Assessment Tool), em uma bacia do município de Piracicaba/SP, sendo que, no primeiro cenário, foi mantido o uso atual de pastagem e de cana-de-açúcar, porém foi criada a vegetação de APP (Área de Preservação Permanente) para os cursos d'água e para as nascentes; no segundo cenário, com solos Litólicos e Podzólicos, substitui-se a pastagem das áreas das encostas com declividade superior a $45^{\circ}$ por vegetação florestal. Concluiu-se que, nos dois cenários, houve diminuição na produção de sedimentos, porém, no segundo cenário, a diminuição foi de $94 \%$, contra $10,8 \%$ do primeiro.

Atualmente vários trabalhos utilizam como ferramenta produtos de sensoriamento remoto e geoprocessamento em trabalhos relacionados ao uso 
do solo. Tal opção decorre da facilidade de identificação das classes e, dependendo da resolução da imagem, até o manejo trabalhado, permitindo resultados satisfatórios em pouco espaço de tempo e maior comodidade. 


\section{3 ÁREA DE ESTUDO}

A Bacia do Córrego Baguaçu possui aproximadamente $614 \mathrm{~km}^{2}$ de área, e extensão de $55 \mathrm{~km}$, desde a sua nascente até a foz, no Rio Tietê, no município de Araçatuba/SP. Localizada no Planalto Ocidental Paulista, uma região que oferece graves problemas relacionados à erosão, isso devido a aceleradas e desordenadas transformações antropogênicas, o Córrego Baguaçu é ocupado por pastagem e por culturas, sendo predominante a cultura da cana-de-açúcar, além de que parte da área urbana de Araçatuba está localizada na bacia. Acrescente-se que $70 \%$ da população de Araçatuba é abastecida pelas águas desse córrego, além de parte dos municípios de Birigui, Bilac, Clementina, Braúna, Coroados e Gabriel Monteiro (Figura 3).

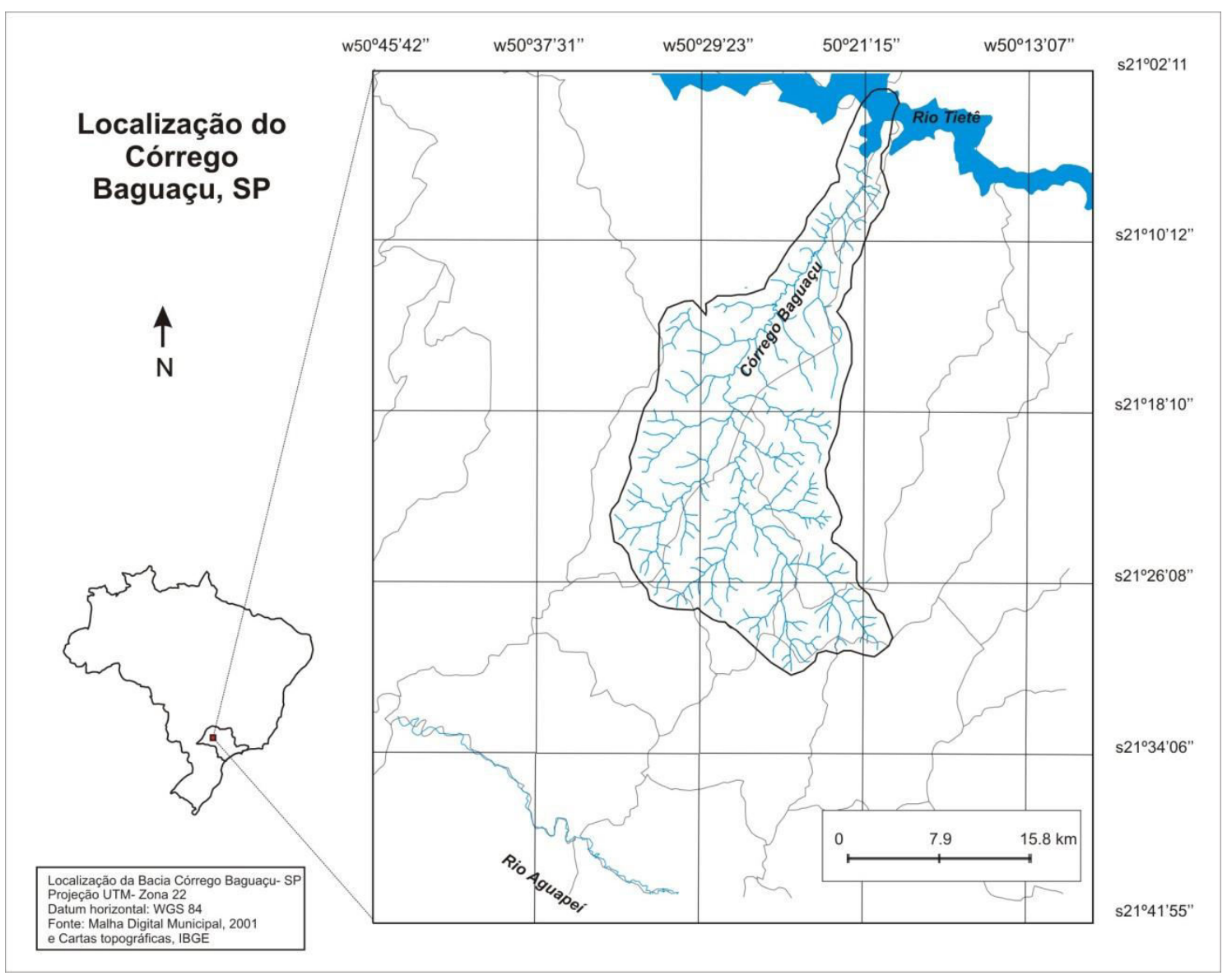

Figura 3 - Mapa de localização da Bacia do Córrego Baguaçu. 
A porção oeste do estado de São Paulo possui grande número e diversidade de ocorrências de processos erosivos devido à retirada agressiva da vegetação natural e sua substituição por culturas pertinentes de acordo com as necessidades de cada período histórico no último século e meio, aproximadamente. O processo é agravado, pois se alia à pobreza das características naturais dos diferentes tipos de solos existentes na região (BOIN, 2000).

O processo de ocupação na região inicia-se a partir de 1850, com 0 declínio da extração aurífera e de pedras preciosas em Minas Gerais e com o início da vigência da Lei de Terras, desse mesmo ano, que propiciou a ocupação de terras devolutas pelos posseiros, sendo essa ocupação chamada de frente de expansão (GUIRARDELLO, 2002).

Mesmo assim, porém, até meados de 1880, a grande concentração de colônias está em torno de Bauru, com grandes plantações de café, atraindo interesses para a construção da estrada de ferro, além de atrair grandes cafeicultores para comprar terras mais baratas ou até gratuitas para plantação de café. Esse novo processo de ocupação é denominado frente pioneira, ou seja, frente voltada para a apropriação de terras, diferente da frente de expansão, que possuía um caráter de subsistência (GUIRARDELLO, 2002).

A necessidade de terras para a plantação do café demandará que grandes áreas sejam desmatadas e que ocorra o desmantelamento das tribos indígenas habitantes na região. Foram esses os fatores diretamente responsáveis pela apropriação de terras na região, propiciando a construção da Estrada de Ferro Noroeste Brasil em 1905, que liga Bauru com Porto Esperança, no atual Mato Grosso do Sul, em 1914, percorrendo 1.272 km.

A construção da Estrada de Ferro foi feita na parte mais elevada, ou seja, no interflúvio do Rio Tietê e do Rio Aguapeí com o Rio Feio e o desenvolvimento das cidades ao longo da estrada de ferro se dá pela necessidade de escoamento do café, e do transporte de passageiros nas estações.

Outras culturas foram plantadas na região, como amendoim, algodão e arroz, até serem substituídas pela criação de gado nas décadas de 1940 e 
1950. Posteriormente, em 1970, com a criação do Proálcool, a cultura de canade-açúcar tornou-se majoritária em extensão de ocupação.

A partir de então, como define Ross (2006), o processo de modernização na agricultura é dinâmico nas rápidas mudanças de pastagens de campos naturais, cerrados e cafezais em extensas plantações de soja, milho, trigo, algodão, cana-de-açúcar e pastos com capim braquiária, tratandose de um macrocorredor produtivo, resultado da modernização da agricultura e da pecuária brasileira nos últimos 30 anos.

De acordo com Ross (2006), a cana-de-açúcar vem substituindo cafezais degradados e pastagens em relevos de colinas amplas de vertentes pouco inclinadas, pois essas áreas favorecem a mecanização, além de que o clima é tropical, com chuvas abundantes e com alta insolação, como ocorre na Bacia do Córrego Baguaçu. As transformações na paisagem, geradas pela substituição do pasto e de outras culturas agrícolas, decorrem da necessidade da grande demanda de matéria-prima (cana) para abastecimento das usinas instaladas na região (SUGUIMOTO, 2011).

\subsection{Geologia}

O histórico geológico é dado pela evolução histórica da bacia sedimentar do Paraná. Na Bacia do Rio Paraná, a formação das rochas basálticas foi dada pelo intenso vulcanismo do período Cretáceo, cujas condições ainda eram desérticas na área da bacia, aliadas às perturbações tectônicas, o que gerou arqueamentos e soerguimentos das bordas, causando falhamentos (CETEC, 1999).

A evolução da Bacia Hidrográfica do Rio Paraná se deu por eventos orogenéticos na borda Gondwana e a litosfera oceânica do Panthalassa, sendo que esses episódios decidiram a evolução paleozoica-mesozoica da Bacia do Rio Paraná, pois esses intervalos de subsidência e de orogênese permitiram a criação de ciclos de deposição na área intracratônica (MILANI et al., 2007). 
A Bacia Hidrográfica do Rio Paraná é constituída por séries de deposições que ocorreram em intervalos no tempo ao longo de milhões de anos, desde quando ainda havia um suposto continente único, denominado Pangeia. Os pacotes de deposição são depósitos rochosos materializados e envelopados por superfícies de discordância de caráter inter-regional, sendo eles: Rio Ivaí (Ordoviciano-Siluriano), Paraná (Devoniano), Gondwana (Carbonífero-Eotriássico), Gondwana II (Meso- a Neotriássico), Gondwana III (Neojurássico-Eocretáceo) e Bauru (Neocretáceo) (MILANI et al., 2007).

A área de estudo está situada no Planalto Ocidental Paulista, que representa uma parcela expressiva da Bacia do Rio Paraná, ocupando aproximadamente $50 \%$ do estado de São Paulo, cujas formações Serra Geral, Adamantina e Santo Anastácio compõem o Grupo Bauru na área de estudo.

Na Formação Adamantina da Unidade Aquífera Bauru, ali se encontram camadas espessas de arenitos finos a muito finos, ocorrendo menos as variações grosseiras, com cores róseas e acastanhadas, com intercalações de lamitos e siltitos lamíticos (SALOMÃO, 1994).

A Formação Santo Anastácio apresenta arenitos médios a finos, dominantemente finos, pouca matriz e maciços, cor vermelho escuro. Encontram-se esses arenitos nas porções mais baixas, próximos ao Rio Tietê (Figura 4).

A Formação Serra Geral, da Unidade Aquífera Serra Geral, é composta por Basaltos toléticos em derrames tabulares superpostos e arenitos intertrapianos. É aflorado ao longo no Rio Tietê e afluentes na porção leste, e a oeste ao longo de parte do Rio Paraná. Os solos de alteração e residuais, vermelho-escuros e argilosos, possibilitam identificar diretamente a presença de basaltos da Formação Serra Geral, sendo que esta aflora ao longo de vales do Rio Tietê.

Quanto à drenagem, os Rios Tietê, Aguapeí, Peixe, São José dos Dourados e Santo Anastácio correm em direção ao Rio Paraná, no sentido da inclinação das camadas sedimentares e se configuram como a drenagem consequente mais importante do Planalto Ocidental (SUDO, 1981). 


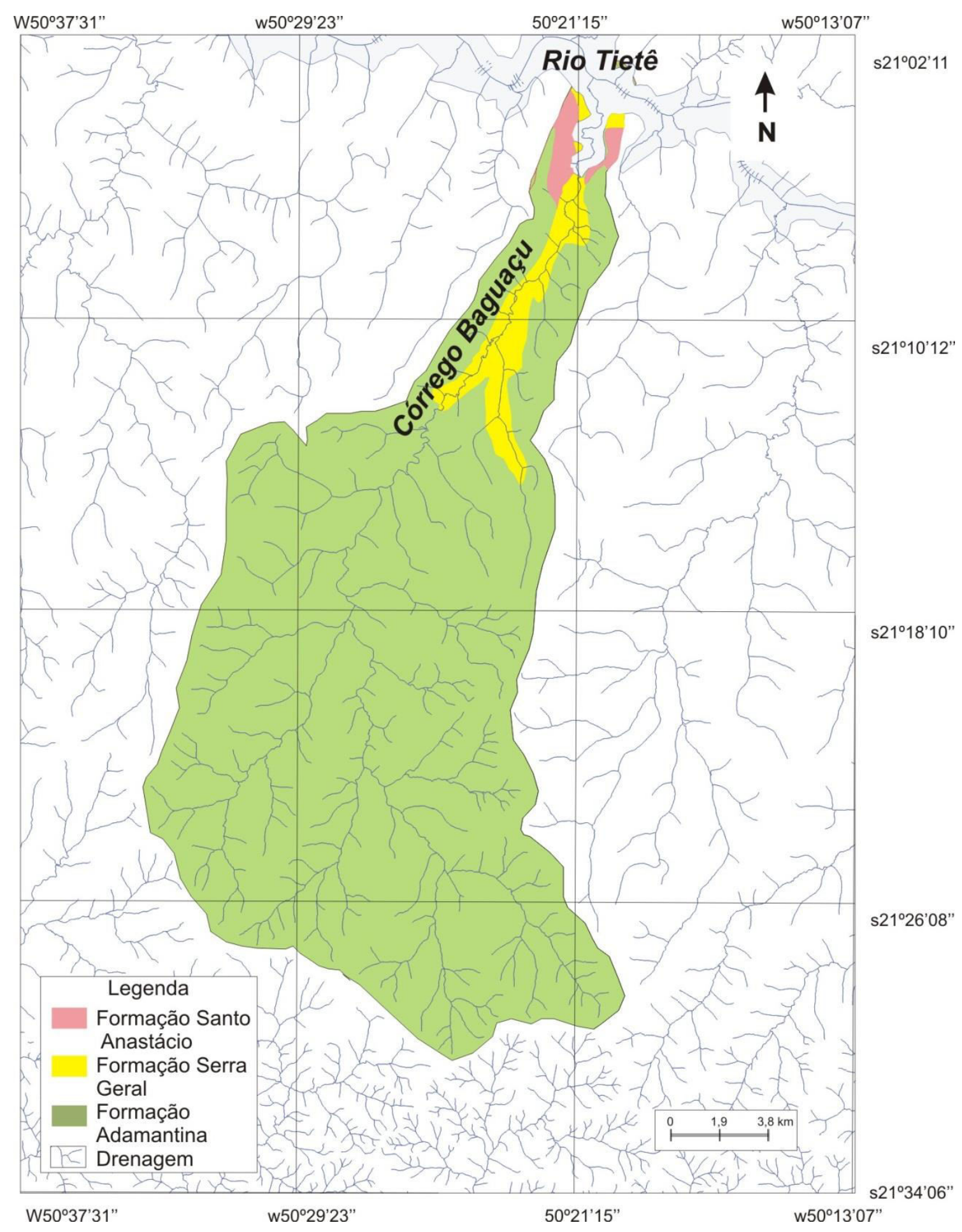

Figura 4 - Mapa geológico da Bacia do Córrego Baguaçu.

\subsection{Geomorfologia}


A geomorfologia da área, de maneira geral, constitui relevos de degradação: Colinas Amplas e Médias, com longas encostas e baixas declividades (Figura 5).

Sudo (1981) afirma que o Planalto Ocidental é uma área extensamente erodida, sendo rebaixada, onde os divisores dos rios consequentes aparecem com extensos espigões tabuliformes recortados por vales laterais muito dissecados pertencentes a uma drenagem dendrítica e que compõem uma sucessão de interflúvios com caráter colinoso. Os rios principais possuem vertentes bem inclinadas voltadas para seus vales, indicando um entalhamento relativamente fundo desses rios.

De acordo com a CETEC (1999), as camadas sub-horizontais dos arenitos do Grupo Bauru e das rochas efusivas básicas da Formação Serra Geral influenciam fortemente o controle estrutural dos tipos de relevo na área.

As colinas amplas apresentam interflúvios com topos extensos e vertentes de perfis retilíneos e convexos. As colinas médias apresentam interflúvios com topos aplainados e vertentes com perfis convexos a retilíneos, com média a baixa drenagem (CETEC, 1999).

A Bacia do Córrego Baguaçu possui a cota mais alta das curvas de nível de $470 \mathrm{~m}$, e a mais baixa de $320 \mathrm{~m}$, ou seja, uma amplitude de $150 \mathrm{~m} \mathrm{e}$ declividades concentradas entre $0 \%$ a $12 \%$. 


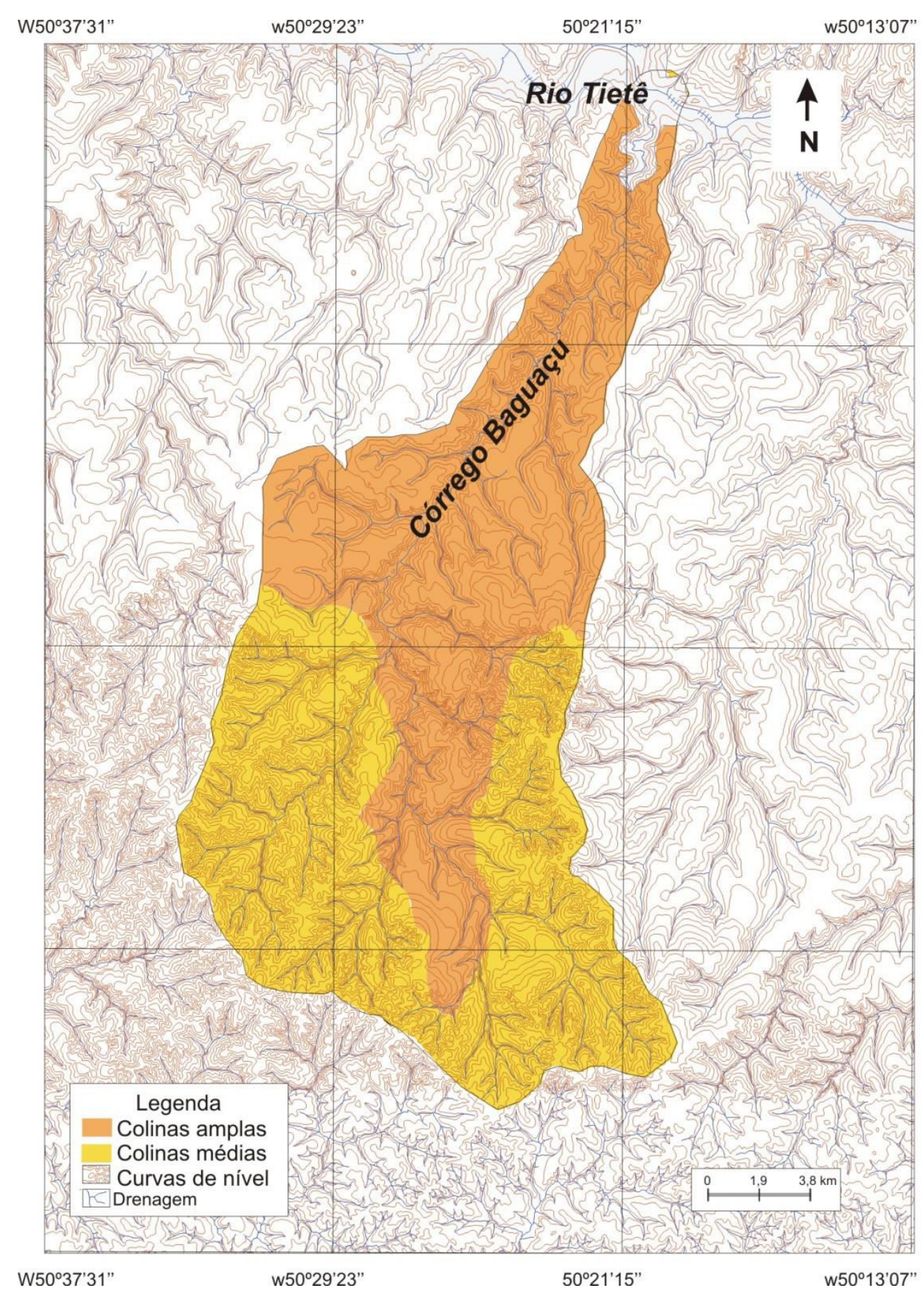

s $21^{\circ} 02^{\prime} 11$

s21ำ'12"

s2 $1^{\circ} 18^{\prime} 10^{\prime \prime}$

s $21^{\circ} 26^{\prime} 08^{\prime \prime}$

s21⒊'06"

Figura 5 - Mapa geomorfológico da Bacia do Córrego Baguaçu.

\subsection{Solos}


Segundo Sudo (1981), a litologia da Formação Bauru é coberta por materiais arenosos e/ou arenoso-argilosos de origem coluvial, que são depósitos cenozoicos ou formações superficiais terciárias/quaternárias. Esse material é responsável pela formação dos solos com $B$ textural: Argissolos de Lins (na classificação anterior eram chamados de Solos Podzolizados), variação Lins; e os solos com B latossólico: Latossolos Vermelho-Escuro, na fase arenosa (Tabela 2).

Tabela 2 - Principais características dos solos do Córrego Baguaçu.

\begin{tabular}{c|c|c}
\hline $\begin{array}{c}\text { Principais } \\
\text { características }\end{array}$ & $\begin{array}{c}\text { Solos da Bacia do Córrego Baguaçu } \\
\text { Lins } \\
\text { Lins }\end{array}$ & $\begin{array}{c}\text { Latossolo vermelho- } \\
\text { escuro fase arenosa }\end{array}$ \\
\hline $\begin{array}{c}\text { Grupo resistência à } \\
\text { erosão }\end{array}$ & Baixo & Alto \\
\hline $\begin{array}{c}\text { Profundidade } \\
\text { Muito profundo (2 a 3 } \\
\text { m) }\end{array}$ & Muito profundo (>2 m) \\
\hline Permeabilidade & Moderada a Rápida & Moderada a Rápida \\
\hline Rextura & $\begin{array}{c}\text { Arenosa no horizonte A } \\
\text { Argilo-arenosa no } \\
\text { horizonte B }\end{array}$ & $\begin{array}{c}\text { Média/Argilosa, com } \\
\text { ligeiro aumento de } \\
\text { argila ao longo da } \\
\text { profundidade do perfil. }\end{array}$ \\
\hline Material de origem & $\begin{array}{c}1,8 \text { e 3,1 } \\
\text { Brenitos de formação } \\
\text { Bauru, com cimento } \\
\text { calcário }\end{array}$ & $\begin{array}{c}\text { Arenitos de formação } \\
\text { Bauru, sem cimento } \\
\text { calcário }\end{array}$ \\
\hline
\end{tabular}

Fonte: Brasil (1960); Bertoni e Lombardi Neto (2012).

De acordo com Salomão (1994), os solos citados acima, associados ao grupo Bauru, caracterizam-se por serem bem desenvolvidos, com horizontes profundos e organizados, sendo que os horizontes superiores apresentam diferenciação do material de origem, devido ao ambiente climático inserido.

\subsubsection{Solos com B textural}


Os solos Argissolos (Argissolo vermelho Eutrófico câmbico textura argilosa/muito argilosa) são solos arenosos cuja formação se deu a partir da formação Bauru, com arenito e cimento calcário, com podzolização acentuada e alta saturação de bases. Possui ainda nítida diferenciação textural entre os horizontes A e B.

O conteúdo de argila do horizonte B textural é maior que o do horizonte A ou E e pode, ou não, ser maior que o do horizonte C (EMBRAPA, 2006), o que o torna mais susceptível à formação de sulcos, pois é criado um gradiente de drenagem entre os horizontes superficial e subsuperficial, que aumenta os processos erosivos na superfície (DEMARCHI, 2012), removendo a camada arável do solo.

Esses solos apresentam grande contraste textural entre os horizontes eluviais e o B textural e, sobretudo, elevada saturação por bases no B textural ou mesmo no "solum" (EMBRAPA, 2006). A textura do horizonte A é friável quando úmido com consistência solta ou macia quando seca (BRASIL, 1960).

Os Argissolos em geral se encontram em relevo suavemente ondulado: apresentando colinas com declives longos e topos levemente arredondados ou achatados, com vales em V muito abertos; e relevo ondulado: colinas com declives menores com topos levemente arredondados e vales em $\mathrm{V}$ fechado. Apresentam solos mais profundos, em torno de 2 a 3 metros, bem drenados e arenosos com gradual diferença entre os horizontes A e B (BRASIL, 1960).

Os perfis feitos no oeste paulista apresentam sequência dos horizontes $A, B$ e $C$, sendo subdivididos em $A^{1}, A^{2}, A^{3}, B 21, B 22, B^{3}$ e $C$. O horizonte $A$ não apresenta mais que $40 \mathrm{~cm}$ de espessura, onde o sub-horizonte $A^{1}$ exibe coloração bruno avermelhado-escura, com baixo teor de argila ( $8 \%$ a 10\%), sendo inferior que o horizonte $B$, com textura de fraca a pequena angular $e$ grão simples. $O$ sub-horizonte $A^{2}$ diferencia-se do $A^{1}$ por possuir duas unidades a mais de croma. Quando úmido, apresenta textura friável. A mudança dos sub-horizontes e horizonte B é gradual (BRASIL, 1960).

O sub-horizonte $A^{1}$ do Argissolo de variação Lins é dificilmente encontrado na área, por ser facilmente removido por erosão laminar, já que a cobertura superficial arenosa (horizonte A) se satura rapidamente, e o 
horizonte de material argiloso abaixo (horizonte B) possui lenta infiltração, gerando, consequentemente, o escoamento superficial (SUDO, 1981).

O horizonte $\mathrm{B}$ comumente apresenta-se subdividido em $\mathrm{B}^{2}$ e $\mathrm{B}^{3}$, com subdivisões em B21, B22 e B23. O sub-horizonte B $^{1}$ é o mais pesado, apresentando maior conteúdo de argila natural (18\% a 33\%), com consistência dura a muito dura quando seco e friável ou firme quando úmido e possui textura geralmente em blocos subangulares. Faz-se diferente do sub-horizonte $\mathrm{B}^{2}$, a estrutura maciça e porosa com gradual passagem entre os sub-horizontes e horizonte $\mathrm{C}$.

O horizonte $\mathrm{C}$ apresenta geralmente $100 \mathrm{~cm}$ com cor mais avermelhada, parecido com o horizonte B e textura mais leve, variando entre "sandy loam" e "loamy sandy". Possui maior índice de silte que o horizonte B e estrutura maciça e porosa.

\subsubsection{Solos com B latossólico}

O principal indicador desses solos é o horizonte B para definir e caracterizar os Latossolos.

São solos com textura média/argilosa, podendo ainda ser francoargilosa, franco-argilo-arenosa, argilo-arenosa e franco-arenosa; sendo que a fração argila é superior a $15 \%$ e de valor igual ou superior que o horizonte $A$ (LEPSCH, 1994).

De acordo com a EMBRAPA (2006, p. 72), são solos que possuem:

[...] evolução muito avançada com atuação expressiva de processo de latolização (ferralitização ou laterização), segundo intemperização intensa dos constituintes minerais primários, e mesmo secundários menos resistentes, e concentração relativa de argilominerais resistentes e/ou óxidos e hidróxidos de ferro e alumínio, com inexpressiva mobilização ou migração de argila, ferrólise, gleização ou plintitização. 
O Latossolo vermelho fase arenosa constitui-se de solos profundos, textura média/argilosa, acentuadamente drenados, de coloração vermelha a vermelho- escura, sendo proveniente do arenito Bauru. A transição de solos é difusa, sendo difícil identificar, devido à pequena variação das características morfológicas (BRASIL, 1960).

Possui os horizontes $A, B$ e $C$, com sub-horizonte $A^{1}$ ou $A p, B^{1}, B^{2}$ e $B^{3}$.

O horizonte A apresenta de 15 a $42 \mathrm{~cm}$ de espessura, com subdivisões em $A^{1}$ ou $A p$ e, às vezes, em $A^{3}$. O sub-horizonte $A^{1}$ varia na cor de bruno avermelhado ao vermelho escuro, com textura "sandy loam" e "sandy clay loam". A estrutura é maciça e porosa, que se desfaz em forma granular pequena fracamente desenvolvida ou granular média fracamente desenvolvida, e possui ainda consistência macia quando seca e friável a muito friável quando úmida. O sub-horizonte $\mathrm{A}^{3}$ apresenta coloração vermelho-escura, com textura granular média fracamente desenvolvida e, quando úmido, é friável e seco, macio.

O horizonte $B$ é subdividido em $B^{1}, B^{2}$ e $B^{3}$, sendo que o sub-horizonte $\mathrm{B}^{1}$ tem cor bruno-avermelhada e vermelha, com textura e consistência similar aos do horizonte A e C, diferenciando no croma, que aumenta uma a duas unidades e, à medida que o perfil se aprofunda, a classe textural fica mais pesada.

Nesses perfis de solos também se observou a ausência do subhorizonte $A^{1}$ devido à erosão. Na Figura 6 encontra-se o mapa pedológico da bacia: 


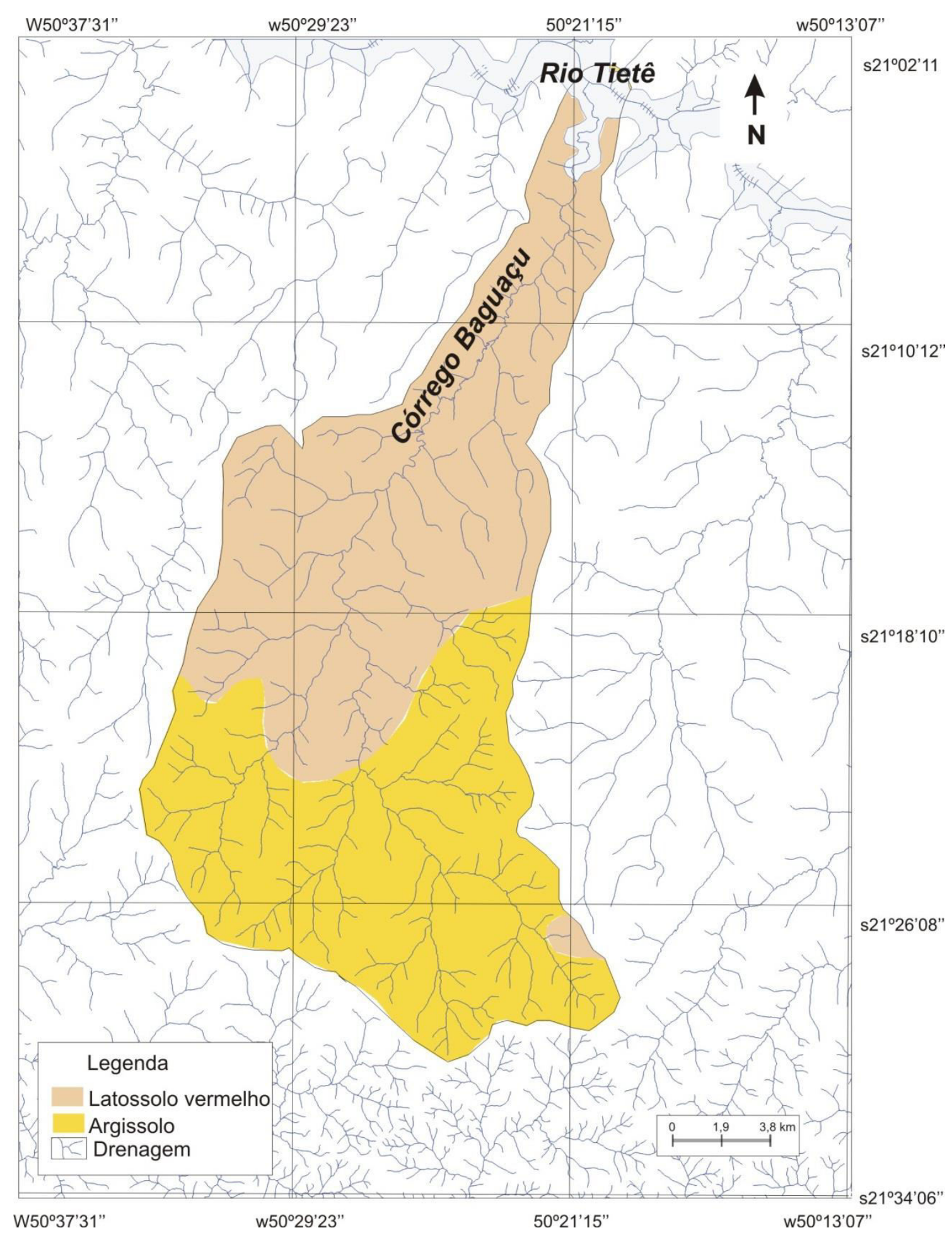

Figura 6 - Mapa pedológico da Bacia do Córrego Baguaçu.

A maior área onde o latossolo vermelho é encontrado está em relevo ondulado, difundindo-se com relevo dos solos Argissolo. O relevo influencia na variação de textura dessa classe de solos, podendo ser um pouco mais leve 
em relevos suavemente ondulados, e textura mais pesada em relevos com altas declividades (BRASIL, 1960).

\subsection{Clima}

A Bacia do Córrego Baguaçu encontra-se localizada na região Aw, de acordo com a classificação de Köppen, com temperatura média entre $19^{\circ} \mathrm{C}$ a $28^{\circ} \mathrm{C}$ e estação seca no inverno.

O período de chuvas se concentra, anualmente, nos meses de setembro a abril e o total de precipitação média mensal não ultrapassa os $250 \mathrm{~mm}$, conforme o gráfico abaixo (Gráfico 1) e a precipitação média anual varia entre 1200 a $1500 \mathrm{~mm}$.

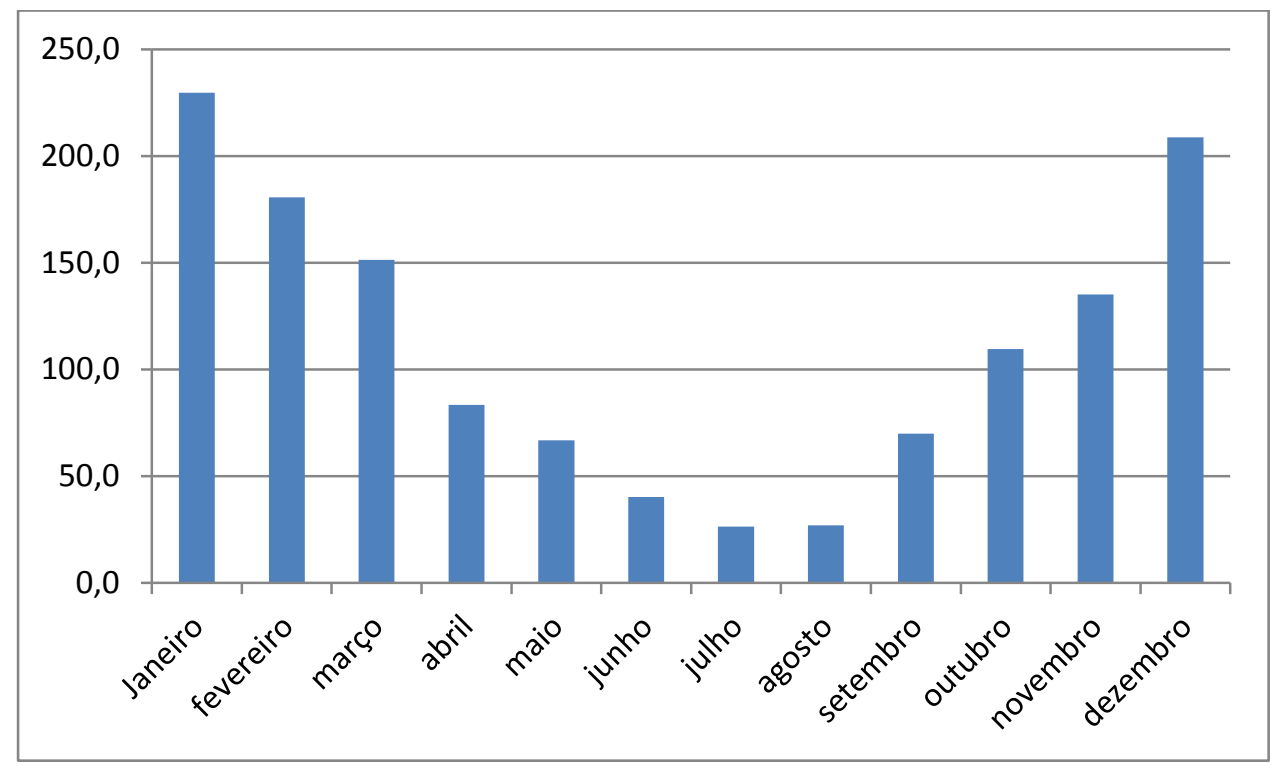

Gráfico 1 - Média da precipitação mensal entre os anos de 1971 e 2000 da região da Bacia do Córrego Baguaçu.

Os dados pluviométricos são os obtidos pelo Departamento Estadual de Água e Energia Elétrica (DAEE) para o munícipio de Araçatuba no período de 1971 a 2000, estando o posto pluviométrico localizado na área da Bacia do Córrego Baguaçu com nome Água Limpa e prefixo C7-073, localizado nas 
coordenadas geográficas $21^{\circ} 20$ de latitude sul e $50^{\circ} 61$ de longitude oeste e altitude de $410 \mathrm{~m}$.

De acordo com Monteiro (1973), a Bacia do Córrego Baguaçu encontrase no setor VIII, onde a principal participação é das massas de Oeste-Noroeste que atuam, no inverno, com o aquecimento pré-frontal, caracterizando chuvas reduzidas no inverno, portanto, clima mais seco (Figura 7).

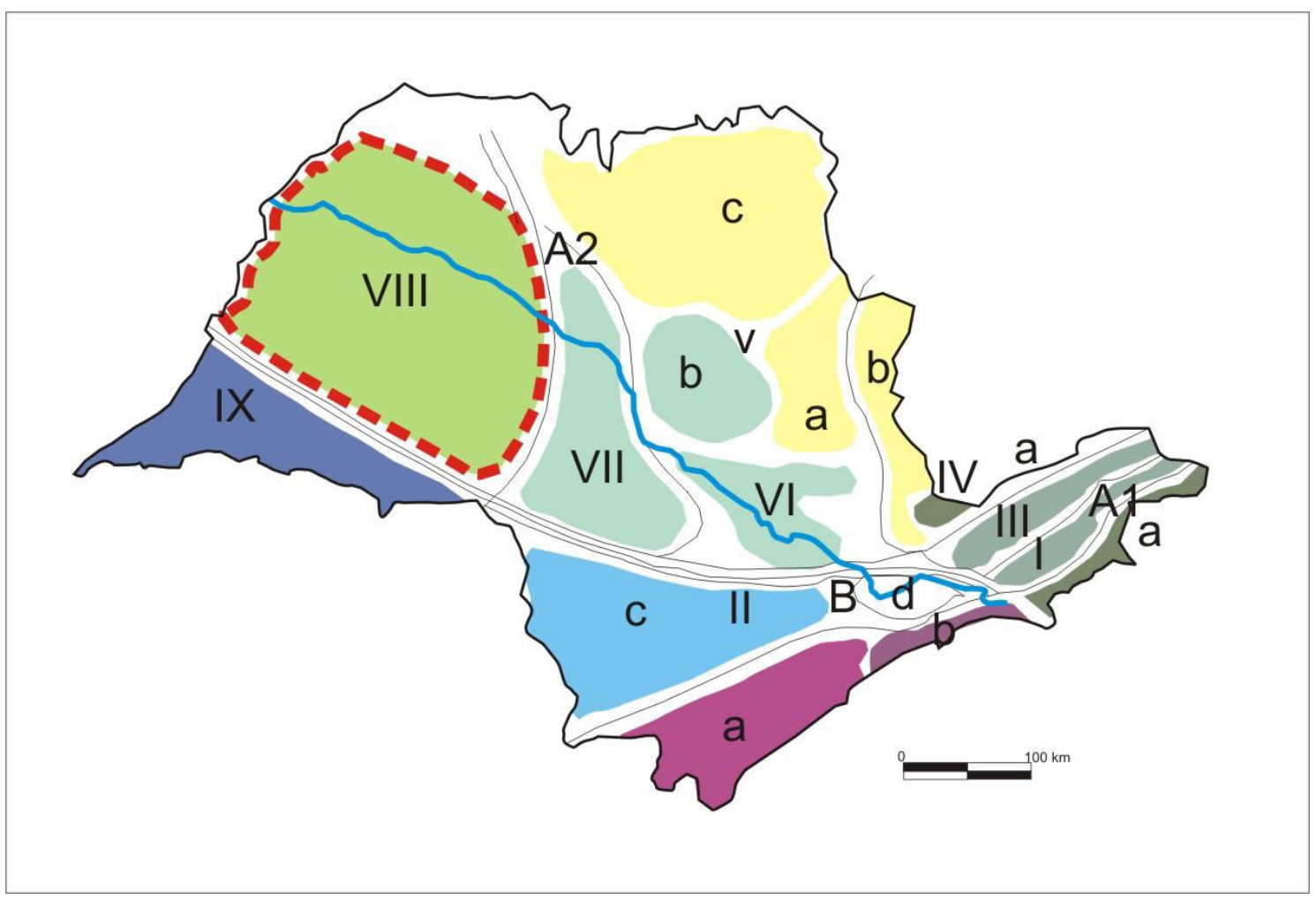

Figura 7 - Representação das feições climáticas do estado de São Paulo. Modificado por - Laís Coêlho do Nascimento Silva (2014).

Fonte - Monteiro (1973).

A Bacia do Córrego Baguaçu possui influência das massas de ar, primeiro, da Tropical Continental, que atua principalmente no verão, sendo seca e quente, proveniente das planícies interiores do continente, e, segundo, da massa de ar Polar Atlântica, originada das altas latitudes, sendo úmida e fria, atuando no inverno. 


\section{MATERIAIS E MÉTODOS}

\subsection{Equação Universal de Perdas de Solos (EUPS)}

Como modelos mais comumente utilizados para a predição de perda de solos, destacam-se a USLE - Universal Soil Loss Equation (empírico), a RUSLE - Revised Universal Soil Loss Equation (empírico/conceitual) e a WEPP - Water Erosion Prediction Project (baseado em processos físicos) (AMORIM, SILVA e PRUSKI, 2009), porém podemos citar outros modelos para a avalição da erosão hídrica, como a MEUPS ou MUSLE (Modified USLE) e o SWAT (Soil and Water Assessment Tool).

Cada modelo serve para um propósito e sua adoção varia de acordo com a situação, levando em conta os parâmetros disponíveis para o local onde o modelo deva ser aplicado (AMORIM, SILVA e PRUSKI, 2009). Minoti (2006) testou quatro modelos (WEPP, GeoWEPP, AnnAGNPS e SWAT) considerando a aplicabilidade dos modelos de predição ao avaliar os seguintes critérios: dados de entrada requisitados, os dados de saída gerados, a possibilidade de interface com SIGs, a análise de sensibilidade das variáveis de entrada utilizadas pelo modelo e a bibliografia disponível.

Considerando os limites e as possibilidades expostos, o modelo EUPS foi escolhido levando em conta os dados disponíveis para a área de estudo, a metodologia aplicável à SIG, e grande oferta de publicações científicas e manuais oferecidos para o seu desenvolvimento.

\subsection{Base cartográfica utilizada}

Para a estimativa de perda de solos por erosão laminar na Bacia do Córrego Baguaçu foi, então, utilizado o modelo empírico da EUPS 
desenvolvido no Spring 4.3.3, que permitiu a análise e a correlação de todas as informações da área em um banco de dados, auxiliando na extração de mapas e de dados para a discussão dos resultados observados. O banco de dados foi configurado com o Sistema de Projeção Universal Transverse Mercator (UTM), e datum horizontal WGS 84 (World Geodetic System) para a zona 22 do hemisfério sul.

A documentação cartográfica do Córrego Baguaçu consiste em mapas que representam os elementos físicos da área, tais como geologia, geomorfologia e pedologia, todos tirados dos relatórios da UGRHI 19, referentes à Bacia Hidrográfica do Baixo Rio Tietê, na escala 1:250000. As bases digitais, como curvas de nível e rede de drenagem, foram obtidas com base nas cartas topográficas do Instituto Brasileiro de Geografia e Estatística (IBGE), na escala de 1:50.000, com equidistâncias das curvas de nível de 10 metros, sendo elas: SF-22-X-C-I-1, SF-22-X-C-I-2, SF-22-X-C-I-4, SF-22-X-CII-1, SF-22-X-C-II-3, SF-22-X-C-II-2, SF-22-X-C-II-4, SF-22-X-C-V-2, SF-22-XC-V-1, SF-22-X-C-I-3, SF-22-X-C-IV-1 e SF-22-X-C-IV-2, sendo importadas para o Spring para posterior digitalização .

Os dados pluviométricos disponibilizados pelo Departamento de Águas e Energia Elétrica (DAEE) de 1971 a 2000 permitiram a análise de chuvas e erosividade, a partir de um posto com registros pluviométricos, posto esse localizado no interior da Bacia do Córrego Baguaçu.

As fotografias ortorretificadas em formato GeoTiff, com resolução de 1 metro e escala de 1:25.000 do período de 2010/2011 (EMPLASA, 2010/2011), possibilitaram maior conhecimento dos tipos de uso e ocupação do solo existentes no período e as práticas conservacionistas, facilitando a sua quantificação e a espacialização.

De maneira simplificada, o fluxograma (Figura 8) representa as etapas realizadas para se alcançar a perda de solos por erosão laminar na Bacia do Córrego Baguaçu. 


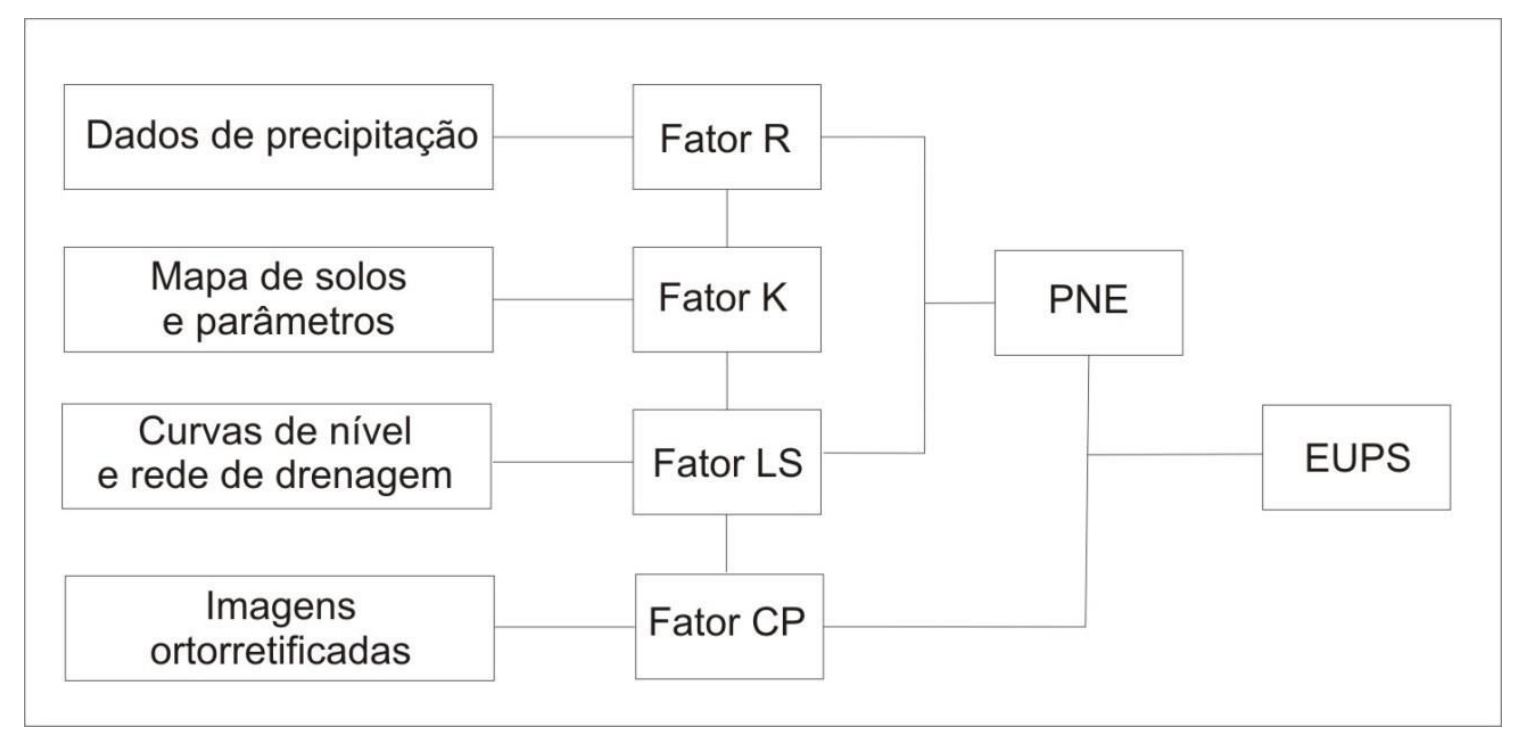

Figura 8 - Fluxograma com etapas para obtenção da EUPS.

\subsection{Fator Erosividade (R)}

Os índices de erosividade médios mensais foram obtidos por meio dos dados de 1971 a 2000, contando-se com os totais anuais e os valores médios mensais de precipitação local (APÊNDICES A e B). Em alguns meses houve falhas nos valores mensais das chuvas, sendo as lacunas preenchidas com a média aritmética dos 30 anos do mês respectivo com falha.

A falta de registro de dados gerados por pluviógrafos foi suprida com os dados de precipitação média mensal e média anual do município de Araçatuba/SP, utilizando a fórmula de Ei30 do município de Votuporanga (COELHO, 2001).

Para verificar a eficiência da equação, calcularam-se os intervalos de confiança entre as médias mensais de Araçatuba e Votuporanga nos anos de 1975 a 1996 para comparar a distribuição de chuva entre os locais. Também foram calculados os intervalos de confiança entre as médias mensais de Araçatuba e Teodoro Sampaio (COLODRO, 1999) para o período de 1976 a 1994, para determinar qual das equações seria mais compatível aos dados de precipitação de Araçatuba. Foram escolhidas as duas localidades por haver 
disponibilidade de dados de erosividade para elas e pela proximidade com a bacia estudada.

Houve compatibilidade dos valores de chuva entre Votuporanga e Araçatuba, sendo possível utilizar a equação proposta por Coelho (2001) para Votuporanga:

$$
E I_{30}=-0,8804 . R_{c}{ }^{2}+65,4290 . R_{c}+62,9790 \quad r=0,9915 ;(p<0,01)
$$

Onde:

El 30= índice de erosividade médio mensal;

$\mathrm{Rc}=$ coeficiente de chuva (produto do quociente entre o quadrado da precipitação média mensal pela precipitação média anual).

$$
\mathrm{p}=\text { grau de liberdade. }
$$

Para a obtenção dos índices de erosividade mensal, os cálculos foram realizados com a fórmula:

$$
\mathrm{Ei}=(\mathrm{PM} . \mathrm{IE}) / \mathrm{PA}
$$

Onde:

Ei= valor de índice de erosividade El30 de um mês;

$\mathrm{PM}=$ total precipitado do mês;

$\mathrm{IE}=$ valor de erosividade $\mathrm{E} \mid 30$ médio mensal;

$\mathrm{PA}=$ precipitação média mensal.

O índice de erosividade anual foi calculado por meio da soma dos valores mensais do índice de erosão (LOMBARDI NETO, MOLDENHAUER, 1992). 
O gráfico de erosividade relativa acumulada foi feito a partir das médias mensais de EI30 (APÊNDICE C).

\subsection{Fator erodibilidade (K)}

A falta de levantamentos amostrais de solos do Córrego Baguaçu foi suprida por meio de pesquisas em trabalhos que apresentassem as devidas características necessárias para a determinação do fator $\mathrm{K}$ e se localizassem próximas a essa bacia.

Assim, foram escolhidos, para determinar o fator $\mathrm{K}$ do Argissolo (antigo Solo Podzolizado-variação Lins), primeiro, o trabalho de Tavares (1986) na Bacia Hidrográfica do Rio São José dos Dourados, localizada a oeste do estado de São Paulo e, segundo, o trabalho de Mardegan (2012), que obteve resultados das amostras do Latossolo vermelho no município de Planalto/SP (Tabela 3):

Tabela 3 - Propriedades físicas e químicas dos solos presentes na Bacia do Córrego Baguaçu.

\begin{tabular}{cccccc}
\hline $\begin{array}{c}\text { Solos do } \\
\text { Córrego } \\
\text { Baguaçu }\end{array}$ & $\begin{array}{c}\text { Matéria } \\
\text { orgânica } \\
(\%)\end{array}$ & $\begin{array}{c}\text { Areia } \\
(\%)\end{array}$ & $\begin{array}{c}\text { Silte + } \\
\text { areia fina } \\
(\%)\end{array}$ & Estrutura & $\begin{array}{c}\text { Permeabi- } \\
\text { lidade }\end{array}$ \\
\hline $\begin{array}{c}\text { Argissolo- } \\
\text { variação Lins }\end{array}$ & 1,5 & 61,2 & 36,1 & $\begin{array}{c}\text { Pequena } \\
\text { granular }\end{array}$ & $\begin{array}{c}\text { Moderada } \\
\text { a rápida }\end{array}$ \\
$\begin{array}{c}\text { Latossolo } \\
\text { vermelho }\end{array}$ & 1,3 & 41,4 & 37,5 & $\begin{array}{c}\text { Pequena } \\
\text { granular }\end{array}$ & $\begin{array}{c}\text { Moderada } \\
\text { a rápida }\end{array}$ \\
\hline
\end{tabular}

Fonte - Tavares (1987), Mardegan (2012) e Oliveira (1999).

Por meio do conhecimento de algumas propriedades físicas e químicas dos solos da região, utilizou-se o método do nomograma de Wischmeier e Smith (1978) para a determinação do fator K do Argissolo variação Lins e do Latossolo vermelho. 


\subsection{Fator Topográfico (LS)}

O fator topográfico (LS) é resultado da integração da declividade em porcentagem e o comprimento de rampa em metros (BERTONI e LOMBARDI NETO, 2012), conforme o cálculo abaixo:

$$
\mathrm{LS}=0,00984 \mathrm{C}^{0,63} \mathrm{D}^{1,18}
$$

Onde:

LS= Fator topográfico

$\mathrm{C}=$ Comprimento de rampa em metros

$D=$ Grau de declive em porcentagem

Para determinar o comprimento de rampa foram necessários os vetores da linha de drenagem e os divisores de água das sub-bacias. Importou-se a drenagem como linhas de quebra e os divisores de água com valor $Z=0$, em um mesmo Plano de Informação, por meio da função mosaico. Com a função mapa de distâncias nas linhas de divisores de água foi criada uma grade com os valores de comprimento de rampa, conforme Tomazoni e Guimarães, (2005); Souza (2010) e Ruthes et al. (2012).

A declividade (Fator $S$ ) foi fixada a partir das curvas de nível com equidistância de 10 metros e pontos cotados, informação essa obtida pelas cartas topográficas. A partir das curvas de nível e dos pontos cotados, gerou-se a grade retangular e a grade triangular, grades que servem para a criação do modelo numérico de terreno. 
Utilizando a programação Legal do Spring (APÊNDICE O), executou-se uma rotina para a criação da grade do fator topográfico (Fator LS), com auxílio da grade de declividade e da grade do comprimento de rampa.

\subsection{Uso e manejo do solo (C)}

Para ser feito o mapa de uso e ocupação do solo, as fotografias ortorretificadas foram importadas em formato GeoTiff para o Spring, aplicando o recorte da Bacia do Córrego Baguaçu, com um polígono da delimitação da bacia previamente feito a partir da rede de drenagem e curvas de nível, delimitados pelos interflúvios.

A classificação das fotografias ortorretificadas foi feita por polígonos, de forma manual, analisando a imagem por meio de fotointerpretação (Tabela 4) e análise em campo, sendo que as classes, identificadas e existentes na Bacia do Córrego Baguaçu no ano de 2011, foram: solo exposto, cana-de-açúcar, culturas anuais, eucalipto, florestal, corpos d'água continentais, planícies de inundação, pastagem e áreas urbanizadas.

Para as culturas anuais foram consideradas apenas soja e milho, porque ocupavam maior área plantada no ano de 2011, segundo o IBGE (2012). As culturas anuais são aquelas em que demoram um ano para completar seu ciclo.

Tabela 4 - Chave de fotointerpretação do uso e ocupação do solo.

\begin{tabular}{c|c|c}
\hline $\begin{array}{c}\text { Amostra da fotografia } \\
\text { ortorretificada }\end{array}$ & Classe de uso & $\begin{array}{c}\text { Características de } \\
\text { Interpretação }\end{array}$ \\
\hline & $\begin{array}{c}\text { Corpos d'água } \\
\text { continentais }\end{array}$ & $\begin{array}{c}\text { Cor: azul-escura ou } \\
\text { azul-clara } \\
\text { Textura: lisa } \\
\text { Forma: irregular }\end{array}$ \\
\hline
\end{tabular}




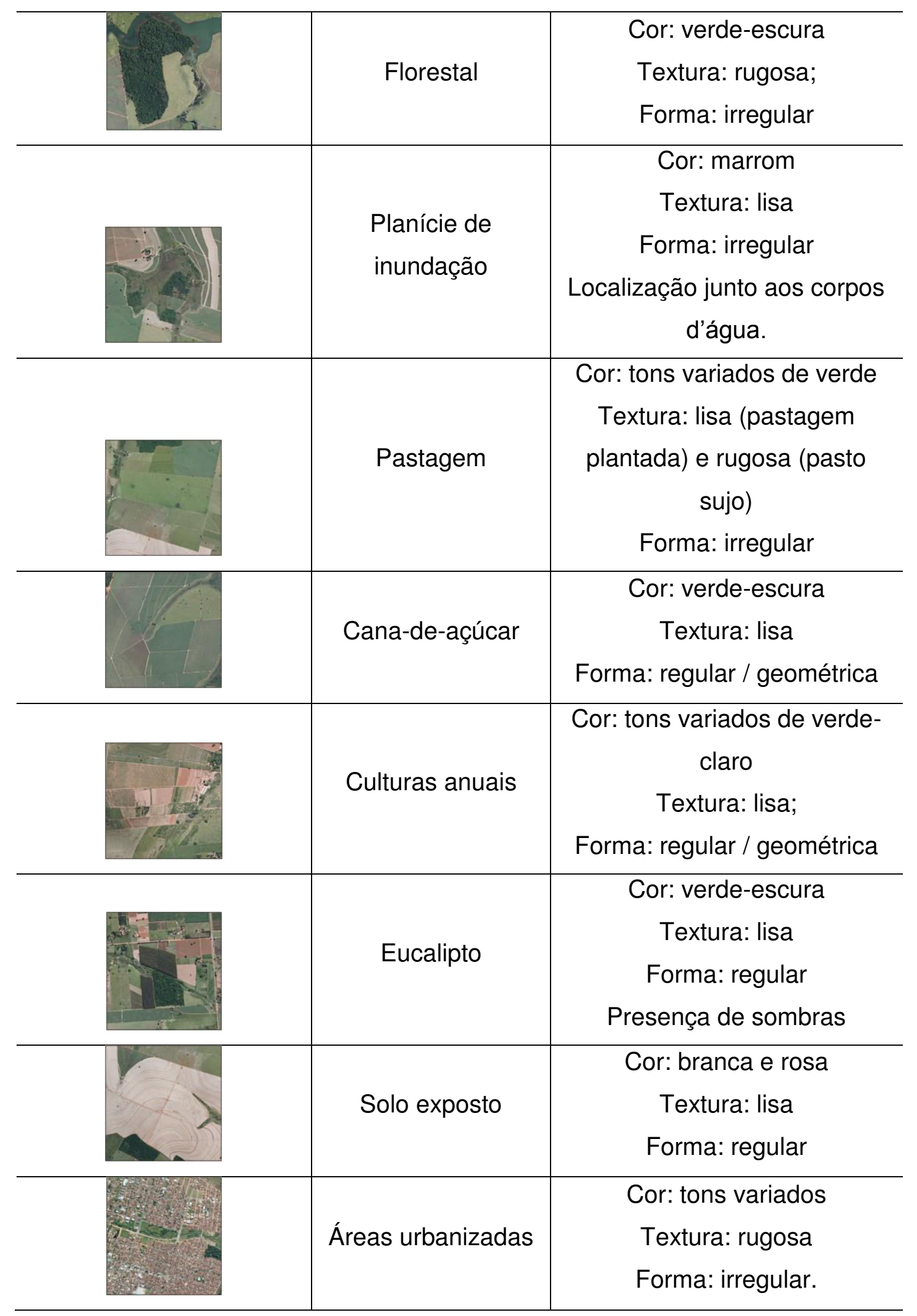

Para a determinação do Fator $C$ foi utilizada a metodologia de Wischmeier \& Smith (1968), sendo considerados os estágios de 
desenvolvimento das culturas da soja, do milho e da cana-de-açúcar, ou seja, desde o preparo do solo para o cultivo da cultura até o período de colheita, atribuindo, para cada estágio, a razão de perda de solos para o manejo de tais culturas (APÊNDICE D a M). Os tipos de manejos para as culturas da bacia foram identificados como as mais usuais na região (CARVALHO, 2012), sendo que, ao término dos cálculos do fator $C$ para cada cultura com respectivo manejo, utilizou-se a média dos valores para as culturas de soja, de milho e de cana-de-açúcar.

No caso da cana de ano de 12 meses, o ciclo de desenvolvimento é iniciado no mês de setembro, sendo que no primeiro mês é operada apenas a preparação do solo, no mês de outubro inicia-se o plantio e no mês seguinte é o estabelecimento da cultura, para, nos próximos meses, até julho, haver o crescimento e a maturação da cana, seguindo-se as atividades de colheita e de preparo do solo para novo plantio (APÊNDICE N). Já para a cana de ano e meio, o ciclo é iniciado com o plantio em março, seguindo-se estágios de desenvolvimento, plantio e estabelecimento da cultura como a cana de ano, ou seja, um mês para cada estágio, porém o crescimento e maturação são de 14 meses, iniciado em junho e finalizado em julho do próximo ano, para ser feita a colheita (CARVALHO, 2012).

Para a cana de ano e cana de ano e meio foi considerada a cana planta em cultivo convencional para o plantio e do segundo ao quinto ciclo foi estabelecido valores para a cana soca sem queima.

As culturas anuais (milho e soja) e a pastagem são plantadas com início em setembro, desenvolvimento em outubro, plantio e estabelecimento da cultura em novembro e dezembro, e até agosto ocorre crescimento e maturação.

Para o cultivo da pastagem, calculou-se o fator $C$ para o primeiro ano da pastagem anual e a partir do segundo ao décimo ano, foram calculados valores de RPS para pastagem do segundo ano em diante. No segundo ano em diante da pastagem, são mantidas os mesmos estágios e meses do plantio, com razão de perda de solos menor. Na Tabela 5 estão elencados os valores de 
perda de solos para as principais culturas e manejo encontrados na área de estudo no ano de 2011:

Tabela 5: Razão de perda de solos para culturas da Bacia do Córrego Baguaçu.

\begin{tabular}{l|c|c|c|c|c}
\hline \multirow{2}{*}{ Manejo da cultura } & \multicolumn{5}{c}{ Razão de perda de solo (RPS) no } \\
\cline { 2 - 6 } & $\mathbf{D}$ & $\mathbf{1}$ & $\mathbf{2}$ & $\mathbf{3}$ & $\mathbf{4}$ \\
\hline $\begin{array}{l}\text { Cana planta de ano em preparação } \\
\text { convencional }\end{array}$ & 20 & 16 & 8 & 2 & 6 \\
\hline $\begin{array}{l}\text { Cana planta de ano e meio em } \\
\text { preparação convencional }\end{array}$ & 20 & 16 & 8 & 2 & 6 \\
\hline $\begin{array}{l}\text { Cana soca de ano sem queima } \\
\text { Cana soca de ano e meio sem }\end{array}$ & 4 & 3,2 & 1,6 & 0,4 & 1,2 \\
$\begin{array}{l}\text { queima } \\
\text { Pastagem (plantio) }\end{array}$ & 22 & 18 & 1 & 2 & 7 \\
\hline $\begin{array}{l}\text { Pastagem (segundo ano em diante) } \\
\text { Milho com cultivo contínuo com } \\
\text { palha enterrada }\end{array}$ & 23 & 19 & 17 & 4 & 2 \\
\hline $\begin{array}{l}\text { Soja em cultivo convencional e } \\
\text { contínuo }\end{array}$ & 35 & 30 & 20 & 20 & 5 \\
\hline
\end{tabular}

Fonte - Carvalho (2012).

A RPS é a relação entre as perdas de solos em uma parcela mantida com determinada cultura e outra parcela descoberta.

Para estimativa do Fator $\mathrm{C}$ do eucalipto foi empregada a fórmula abaixo, de acordo com Martins (2005):

$$
C=\sum \frac{\operatorname{RPSi}}{\operatorname{Ri}}
$$

Onde:

C: é o fator cobertura do solo;

I: estágio da cultura;

RPS: Razão de perda de solo, 
R: erosividade da chuva.

Para o fator de $\mathrm{C}$ do eucalipto foi considerado o ciclo de sete anos, que é o tempo necessário para a produção de celulose (Tabela 6):

Tabela 6 - Razão de perda de solos para o eucalipto.

\begin{tabular}{c|c|c|c|c|c|c|c|c}
\hline \multirow{2}{*}{ Cultura } & \multicolumn{8}{|c}{ Razão de perda de solo no estágio (\%) } \\
\cline { 2 - 9 } & 1 & 2 & 3 & 4 & 5 & 6 & 7 & 8 \\
\hline Eucalipto & 1 & 3,2307 & 0,6105 & 0,2763 & 0,0606 & 0,0075 & 0,1573 & 0,086 \\
\hline
\end{tabular}

Fonte - Martins (2005).

Para o Fator $C$ do eucalipto foram utilizados valores de Razão de Perda de Solos de acordo com Martins (2005), que instalou experimentos em áreas de Argissolo Amarelo, Argissolo Amarelo textura média/argilosa, Plintossolo Háplico e Argissolo Amarelo moderadamente rochoso.

\subsection{Prática conservacionista $(P)$}

Por meio das fotografias ortorretificadas foi possível visualizar áreas que possuem ou não alguma prática conservacionista, delimitando-as com polígonos na criação de um mapa temático, cujas classes foram divididas baseadas na classificação e valores empregados por Bertoni e Lombardi Neto (2012) (Tabela 7):

A única prática conservacionista observada na área da Bacia do Córrego Baguaçu é o plantio em contorno em curvas de nível, que seguem as cotas altimétricas reduzindo a velocidade da enxurrada. As curvas foram identificadas pelas linhas em contorno nas culturas, e a ausência de práticas é observada quando a cultura não apresenta nenhum tipo de barreira para evitar erosão, como linhas em contorno ou degraus. 
Tabela 7 - Valores de $\mathrm{P}$ da equação de perda de solos para algumas práticas conservacionistas.

\begin{tabular}{l|c}
\hline \multicolumn{1}{c|}{ Práticas conservacionistas } & Valor de P \\
\hline Plantio morro abaixo & 1,0 \\
Plantio em contorno & 0,5 \\
\hline
\end{tabular}

Fonte - Adaptado de Bertoni e Lombardi Neto (2012, p. 266).

As práticas conservacionistas foram identificadas nas fotografias ortorretificadas, conforme a chave de fotointerpretação (Tabela 8):

Tabela 8 - Chave de fotointerpretação das práticas conservacionistas.

\begin{tabular}{c|c|c}
\hline $\begin{array}{c}\text { Amostra da } \\
\text { fotografia } \\
\text { ortorretificada }\end{array}$ & $\begin{array}{c}\text { Práticas } \\
\text { conservacionistas }\end{array}$ & $\begin{array}{c}\text { Características de } \\
\text { interpretação }\end{array}$ \\
\hline & Plantio morro abaixo & $\begin{array}{c}\text { Nenhuma prática } \\
\text { identificada }\end{array}$ \\
\hline & Plantio em contorno & Identificação de linhas \\
& & em contorno \\
\hline
\end{tabular}

\subsection{Potencial Natural a Erosão- PNE}

O Potencial Natural à Erosão é resultado da interação entre os principais elementos da natureza responsáveis pela erosão laminar (relevo, erosividade 
da chuva e erodibilidade do solo) em áreas destituídas de cobertura vegetal devido à intervenção antrópica (STEIN et al., 1987).

Para a obtenção do PNE foram integrados os fatores naturais da EUPS, sendo eles $R, K, L$ e $S$ desenvolvidos em Linguagem do LEGAL (Linguagem Espacial para Geoprocessamento Algébrico) (APÊNDICE R) no Spring 4.3.3, desenvolvido por meio da fórmula:

\section{$\mathrm{PNE}=$ R.K.LS}

PNE = Potencial Natural à Erosão laminar calculada em unidade de área, t/ha.ano

$\mathrm{R}=$ erosividade da chuva (MJ.mm/ha.h.ano);

$\mathrm{K}=$ erodibilidade do solo (t.ha.h/ha.MJ.mm);

$\mathrm{L}=$ Fator comprimento de rampa (adimensional)

$\mathrm{S}=$ Fator grau de declive do terreno (adimensional).

Segundo Stein et al. (1987), devido a várias limitações, os resultados alcançados devem ser expressos de forma qualitativa e não quantitativamente, sendo agrupados nas seguintes classes: 0 a 120 (muito baixa); 120 a 250 (baixa); 250 a 500 (média); 500 a 700 (alta) e >700 (muito alta).

\subsection{Estimativa de perda de solos}

O mapa de estimativa de perda de solos é resultado da integração dos fatores da EUPS anteriormente calculados, ou seja, a erosividade da chuva $(\mathrm{R})$, erodibilidade do solo (K), fator topográfico do relevo (LS), uso e ocupação (C) e práticas conservacionistas $(P)$.

Utilizando a ferramenta LEGAL do Spring (APÊNDICE S), relacionaramse todos os fatores, conforme a equação: $A=R^{*} K^{\star} L S^{*} C^{\star} P$, por meio das 
grades com valores numéricos de cada fator, gerando uma grade final para fatiamento das classes de perdas de solo.

\subsection{Expectativa quanto à erosão laminar em função dos fatores antrópicos}

De acordo com Stein et al. (1987), a expectativa à erosão laminar em função dos fatores antrópicos representa a susceptibilidade à erosão laminar nas glebas de uso antrópico, sendo resultado da diferença entre a ocupação atual e a ocupação que é tolerada naturalmente pela gleba:

$\mathrm{CP}_{\mathrm{a}}-\mathrm{CP}_{\mathrm{t}}$

Onde:

$\mathrm{CP}_{\mathrm{a}}=$ Fator $\mathrm{C}$ e $\mathrm{P}$ atual;

$\mathrm{CP}_{\mathrm{t}}=$ Fator $\mathrm{C}$ e $\mathrm{P}$ tolerável.

O valor de $\mathrm{CP}_{\text {atual }}$ é resultado do mapa de ponderação do uso e ocupação e das práticas conservacionistas, atribuindo os valores do Fator C para cada classe de uso e os valores de $\mathrm{P}$ para práticas. $\mathrm{O}$ valor de $\mathrm{CP}_{\text {tolerável }} \mathrm{e}$ obtido pela fórmula:

$$
\text { CPtolerável }=\frac{\mathrm{T}}{\mathrm{PNE}}
$$

Onde:

$\mathrm{T}$ = Perdas permissíveis de erosão para cada tipo de solo;

PNE =Potencial natural à erosão laminar (R. K. LS). 
Para a ponderação dos valores de tolerância de perda de solo para os solos da Bacia do Córrego Baguaçu, Argissolo e Latossolo Vermelho foram utilizados os valores propostos por Bertoni e Lombardi Neto (2012), de 4,5 e 15,0 t/ha.ano, respectivamente.

A fórmula foi introduzida na ferramenta LEGAL (APÊNDICE $P$ e $Q$ ), sendo gerada uma grade com valores menor que 0 a maior que 0.09 , aplicando o Fatiamento na grade para gerar o mapa temático.

O mapa de feições erosivas foi feito a partir das fotografias ortorretificadas, identificando áreas com erosão laminar (sulcos) (Tabela 9).

Tabela 9 - Chave de fotointerpretação de erosão laminar.

\begin{tabular}{c|c|c}
\hline $\begin{array}{c}\text { Características } \\
\text { de interpretação }\end{array}$ & \multicolumn{2}{|c}{ Amostra da fotografia ortorretificada } \\
\hline & \multicolumn{1}{|c|}{$\mid$} & \\
Cor branca, rosa- \\
clara em feições \\
linear ou irregular.
\end{tabular}

Para a identificação das áreas com sulcos nas fotografias áreas foram analisadas áreas com cicatrizes, que apresentam feições linear e irregular, e tom geralmente rosa-claro. São áreas com ausência de cobertura vegetal devido à remoção da camada superficial do solo. 


\section{RESULTADOS E DISCUSSÃO}

Neste capítulo são apresentados os resultados, as comparações e as discussões dos fatores da EUPS individualmente, sendo, ao final, apresentada a da integração de tais fatores, resultando na estimativa de perda de solos por erosão da Bacia do Córrego Baguaçu.

\subsection{Fator $R$}

A distribuição mensal e anual da precipitação pluviométrica foi representada por uma série de 30 anos (1971 a 2000) utilizada para calcular o fator $\mathrm{R}$, sendo que a precipitação média anual observada em Araçatuba é de $1238,1 \mathrm{~mm}$, com desvio padrão de $207,7 \mathrm{~mm}$ e erro padrão de $37,9 \mathrm{~mm}$ de média. O coeficiente de variação foi de $16,7 \%$.

A adequação do número de anos de registros de dados de erosividade ao nível de 1\% revelou ser de 11,6 anos; ao nível de 5\% de 9,0 anos, e ao nível de 10\%, 8,1 anos. O tempo mínimo aceitável de dados para a obtenção do fator $\mathrm{R}$ de Araçatuba (SP), ou seja, a série de 30 anos utilizada para determinar o fator $\mathrm{R}$ da Bacia do Córrego Baguaçu, é suficiente para determinar tal fator.

Na Figura 9 é apresentado o intervalo de confiança entre as médias mensais de Araçatuba e de Votuporanga nos anos de 1975 a 1996, sendo possível observar que há sobreposição entre as precipitações médias dos dados. O coeficiente de correlação $(r)$ obtido para a regressão linear entre os dados médios anuais de precipitação de Araçatuba e de Votuporanga foi de 0,9988, optando pela utilização da equação proposta por Coelho (2001) para Votuporanga para Araçatuba, também pela proximidade entre as duas localidades. 


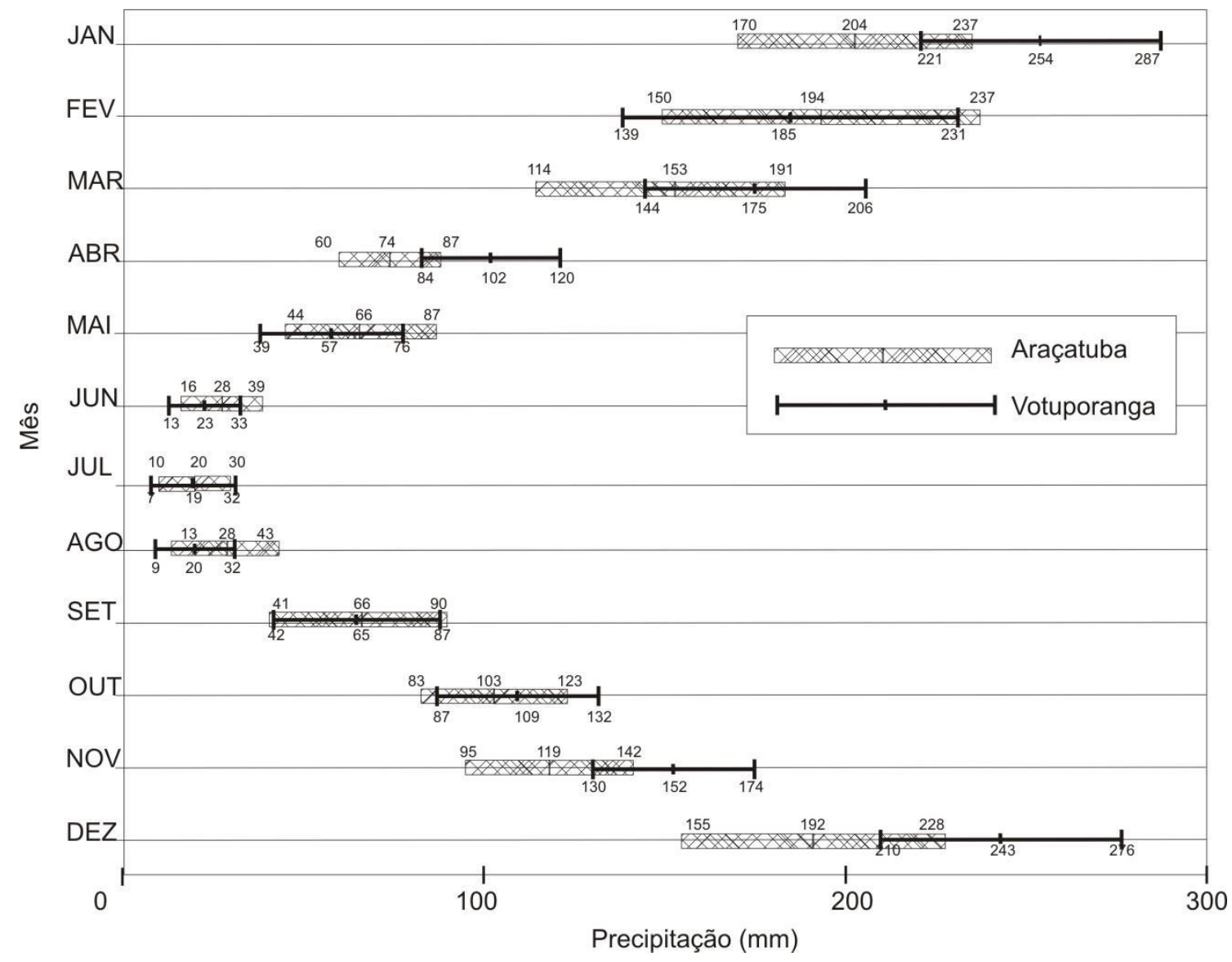

Figura 9 - Intervalo de confiança da precipitação média mensal de Araçatuba (SP) e Votuporanga (SP) no período de 1975 a 1996.

A dificuldade de se obter valores de El30 para o índice de fator $\mathrm{R}$ foi suprida pela metodologia já utilizada por Colodro et al. (2002), Roque et al. (2001), Kuritani (2001), Coelho (2001) e Moreti et al. (2003), que permite utilizar a fórmula do índice de erosividade médio mensal de uma localidade próxima no caso da ausência de dados locais. O resultado mostrou-se satisfatório, com resultados compatíveis para a região, mostrando ser uma alternativa para a obtenção do índice.

Com a distribuição de erosividade da chuva nos meses e nos anos para a série de dados de 1971 a 2000 de Araçatuba foi obtido o fator $\mathrm{R}$ de Araçatuba de 7099 MJ.mm/ha.h.ano, com desvio padrão e erro padrão da média de 1216 e 222 MJ.mm/ha.h.ano, respectivamente, com coeficiente de variação de $17,1 \%$. 
$\mathrm{Na}$ Tabela 10 estão apresentados os valores médios mensais e médio anual de precipitação pluviométrica, coeficientes de chuva e índices de erosividade médios mensais de Araçatuba entre o período de 1971 a 2000.

Tabela 10 - Valores médios mensais e médios anuais de precipitação pluviométrica, coeficientes de chuva e índices de erosividade médios mensais de Araçatuba (SP) entre o período de 1971 a 2000.

\begin{tabular}{|c|c|c|c|}
\hline Mês & $\begin{array}{l}\text { Precipitação } \\
\text { Média Mensal }\end{array}$ & $\begin{array}{l}\text { Coeficiente de } \\
\text { Chuva (Rc) }\end{array}$ & $\begin{array}{c}\text { El } 30 \text { médio } \\
\text { Mensal } \\
\text { calculado }\end{array}$ \\
\hline & \multicolumn{2}{|c|}{$\mathrm{mm}$} & MJ.mm/ha.h.ano \\
\hline Jan. & 205,6 & 34,15 & 1271 \\
\hline Fev. & 184,4 & 27,47 & 1196 \\
\hline Mar. & 150,6 & 18,32 & 966 \\
\hline Abr. & 73,1 & 4,32 & 329 \\
\hline Maio & 66,2 & 3,54 & 284 \\
\hline Jun. & 35,1 & 1,00 & 127 \\
\hline Jul. & 24,3 & 0,48 & 94 \\
\hline Ago. & 28,0 & 0,63 & 104 \\
\hline Set. & 65,8 & 3,50 & 281 \\
\hline Out. & 102,7 & 8,53 & 557 \\
\hline Nov. & 120,6 & 11,74 & 710 \\
\hline Dez. & 181,6 & 26,64 & 1181 \\
\hline Total & 1238,1 & - & 7099 \\
\hline
\end{tabular}

Os valores extremos médios anuais de erosividade no período de 1971 a 2000 para Araçatuba variaram de 4150 a 9632 MJ.mm/ha.h.ano e os índices de erosividade extremos mensais ocorreram nos meses julho e janeiro, com valores de 94 a $1271 \mathrm{MJ} . \mathrm{mm} / \mathrm{ha}$.h.ano, respectivamente.

O valor médio anual de erosividade apresentado para Araçatuba difere do apresentado por Bertoni e Lombardi Neto (2012) no mapa de isoerosividade do estado de São Paulo, que estão entre 6000 a 6250 MJ.mm/ha.h.ano. O fator R de Araçatuba de 7099 MJ.mm/ha.h.ano foi maior que o de Mirandópolis trabalhados por Kuratani (2001) de 6962 MJ.mm/ha.h.ano e Piraju (7074 MJ.mm/ha.h.ano) (ROQUE et al.,2001), mas inferior ao de São Manuel (7487 MJ.mm/ha.h.ano), Pedrinhas Paulista (7670 MJ.mm/ha.h.ano), e Teodoro Sampaio (7172 MJ.mm/ha.h.ano) calculados por Moreti et al. (2003), Moreti et al. (2003) e Colodro et al. (2002), respectivamente. 
A Tabela 11 apresenta a distribuição da erosividade acumulada de Araçatuba/SP. De acordo com Kuratani (2001), a curva de distribuição da erosividade fornece informações para a determinação do fator cobertura e manejo (C) da EUPS, pois mostra em qual época o maior potencial das chuvas pode causar erosão.

Tabela 11 - Distribuição mensal relativa do índice de erosividade $\mathrm{El}_{30}$ de Araçatuba/SP durante o período de 1971 a 2000.

\begin{tabular}{ccc}
\hline & \multicolumn{2}{c}{ Fração do fator R } \\
\cline { 2 - 3 } Mês & $\mathbf{E l}_{\mathbf{3 0}}$ & $\mathbf{E l}_{\mathbf{3 0}}$ Acumulado \\
\hline \multicolumn{2}{c}{$(\%)$} \\
\hline JUL. & 1,3 & 1,3 \\
AGO. & 1,5 & 2,8 \\
SET. & 4,0 & 6,7 \\
OUT. & 7,8 & 14,6 \\
NOV. & 10,0 & 24,6 \\
DEZ. & 16,6 & 41,2 \\
JAN. & 17,9 & 59,1 \\
FEV. & 16,8 & 76,0 \\
MAR. & 13,6 & 89,6 \\
ABR. & 4,6 & 94,2 \\
MAIO & 4,0 & 98,2 \\
JUN. & 1,8 & 100,00 \\
\hline
\end{tabular}

Por meio dos dados de erosividade mensal é possível identificar que há maior perda de solo por erosão entre os meses de outubro e março, pois $82,8 \%$ do índice de erosividade ocorreram nessa época, e menor perda de solos no semestre complementar, de 17,2\% (abril a setembro), assim como no trimestre de junho a agosto o valor foi de apenas $4,6 \%$. As culturas cultivadas na bacia (cana de ano, milho e soja) são plantadas em setembro, ou seja, no início do período chuvoso, porém é necessária atenção quanto ao manejo nesse período, pois os preparos de solos, como o cultivo convencional, mobilizam a terra, deixando-a exposta a chuvas e a enxurradas no período inicial em que a cultura não oferece proteção ao solo. As culturas de ano e meio, como a cana, é plantada no início de março, ou seja, quando o período de chuvas está terminando. Nesse período até a retomada das chuvas, deve- 
se oferecer proteção ao solo devido à erosão eólica, principalmente em solos arenosos, como é o caso do Argissolo.

O Gráfico 2 mostra a curva de distribuição da erosividade acumulada:

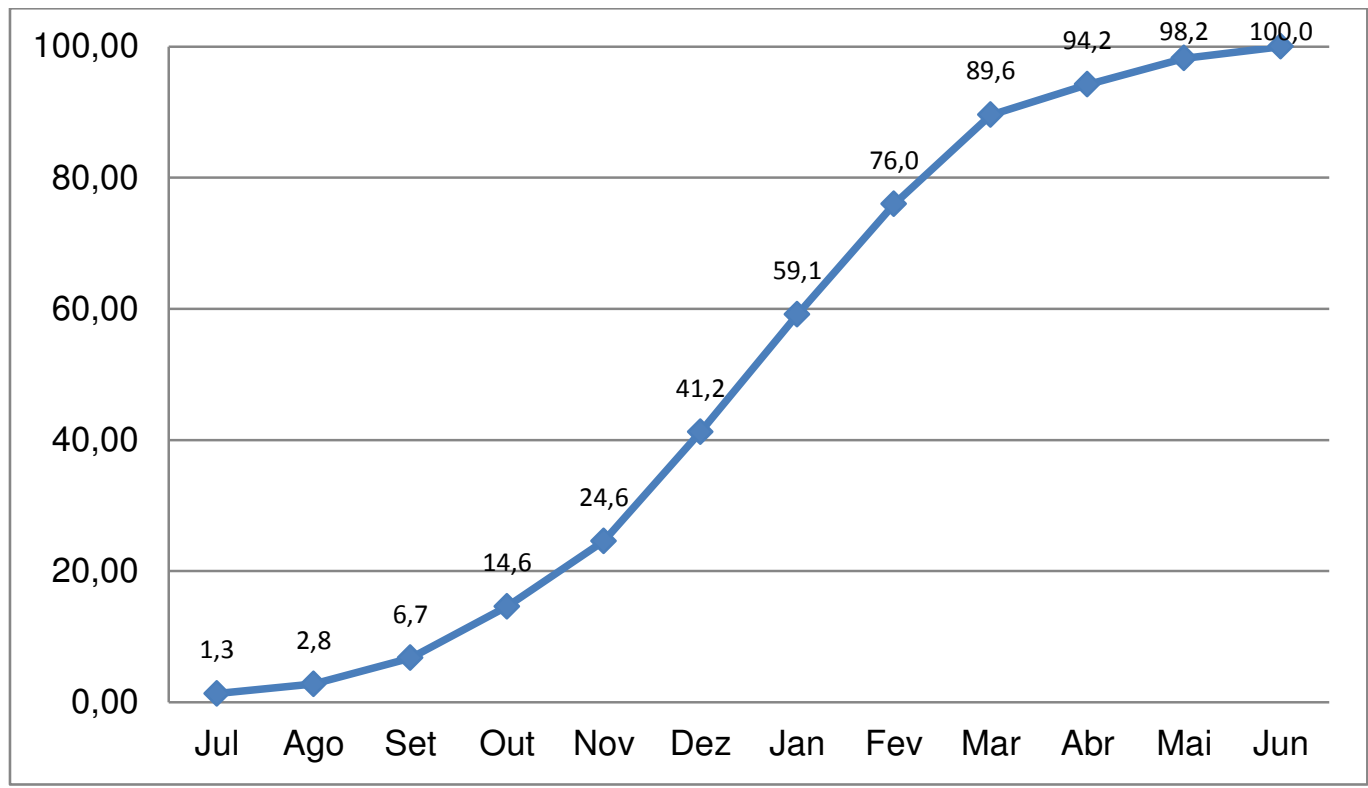

Gráfico 2 - Distribuição relativa acumulada do índice de erosividade $\mathrm{El}_{30}$ médio mensal (\%) de Araçatuba/SP durante o período de 1971 a 2000.

Os trabalhos de Colodro et al. (2002) para Teodoro Sampaio/SP, Roque et al. (2001) para Piraju/SP, Kuratani (2001) para Mirandópolis/SP, Coelho (2001) para Votuporanga/SP e Moreti et al. (2003) para São Manuel/SP apresentam resultados similares para a mesma época de distribuição da erosividade.

\subsection{Fator $\mathrm{K}$}

Os solos na Bacia do Córrego Baguaçu são dois: o Latossolo vermelho distrófico típico com textura média, em sua porção norte, a jusante e o Argissolo Vermelho Eutrófico câmbico A moderado com textura argilosa/muito argilosa na porção sul da bacia, a montante (Figura 10). 
Com os parâmetros estabelecidos, foram determinados os valores do Fator $\mathrm{K}$, por meio do nomograma para o Latossolo vermelho, obtendo o resultado de $\mathrm{K}=0,027$ t.ha.h/ha.MJ.mm e, para os Argissolos, de $\mathrm{K}=0,031$ t.ha.h/ha.MJ.mm. Os resultados foram multiplicado por 0,1317, para a conversão ao Sistema Internacional de Unidades, de acordo com Foster et al. (1981). 


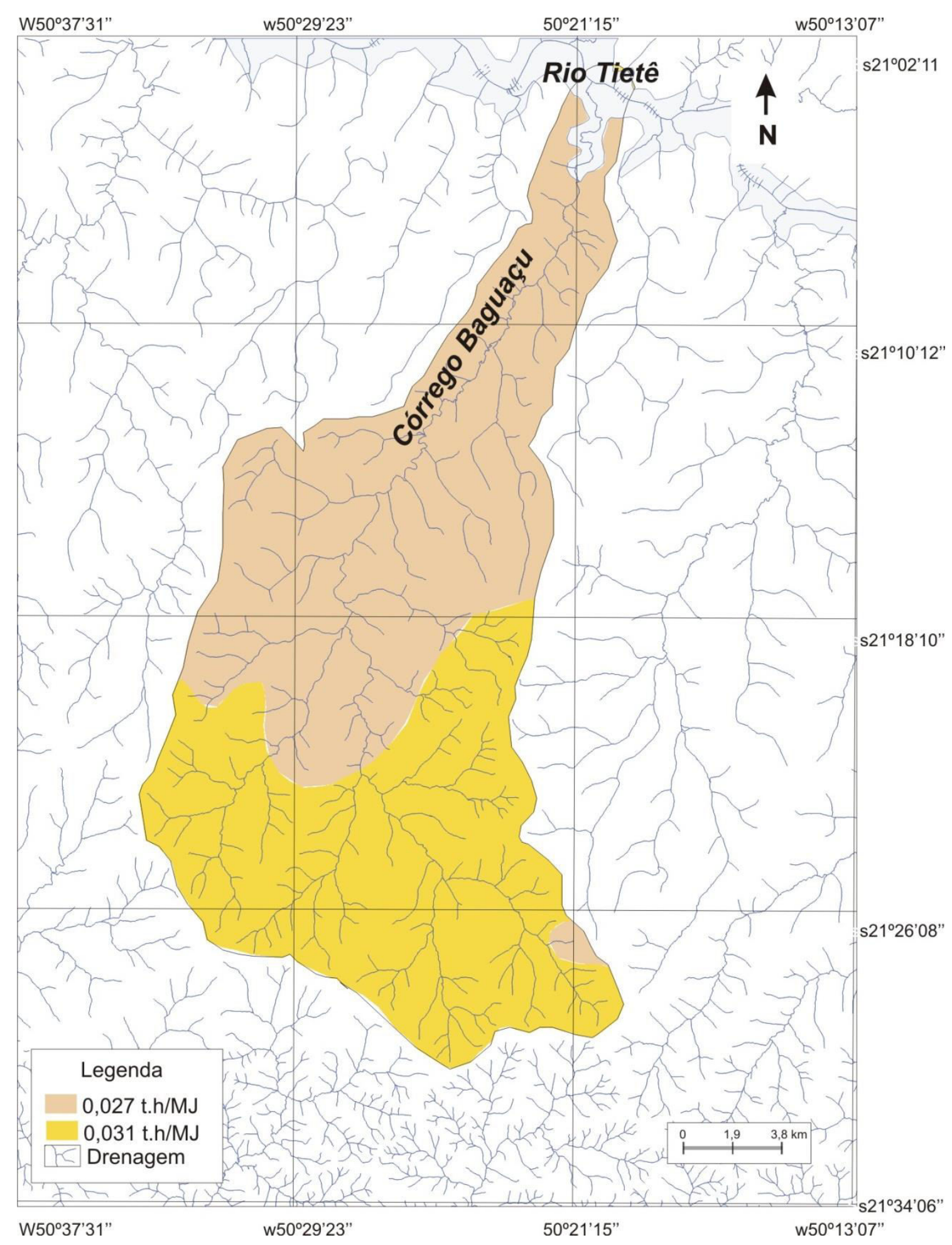

Figura 10 - Fator K dos solos da Bacia do Córrego Baguaçu.

O Latossolo vermelho ocupa $53,1 \%$ de área da Bacia do Córrego Baguaçu, enquanto o Argissolo representa $46,9 \%$ dos solos da bacia (Tabela 12). 
Tabela 12- Erodibilidade dos solos do Córrego Baguaçu e área ocupada pelas classes.

\begin{tabular}{lcc}
\hline \multicolumn{1}{c}{ Índices } & Área $\mathbf{( k m}^{2}$ ) & Percentual (\%) \\
\hline Latossolo vermelho & 325,6 & 53,1 \\
0,027 t.ha.h/ha.MJ.mm & 287,8 & 46,9 \\
$\begin{array}{l}\text { Argissolo } \\
\text { 0,031 t.ha.h/ha.MJ.mm }\end{array}$ & 613,4 & 100 \\
\hline Total &
\end{tabular}

O resultado de fator $K$ para Argissolo variação Lins de 0,031 está próximo ao obtido por Bertoni com relação de erosão no horizonte superficial de 0,035 t.ha.h/ha.MJ.mm, porém o Latossolo vermelho teve resultado de 0,027, e o de Bertoni e Lombardi Neto (2012), de 0, t.ha.h/ha.MJ.mm.

Lagrotti (2000) obteve 0,0167 t.ha.h/ha.MJ.mm para o Latossolo vermelho no município de Santo Antônio de Jardim, no leste do estado de São Paulo e Mannigel et al. (2002) obtiveram valor mais baixo para o Argissolo vermelho Eutrófico câmbico com textura argilosa/muito argilosa de 0,0178 para os solos do estado de São Paulo.

Os solos da Bacia do Córrego Baguaçu possuem forte gradiente textural entre os horizontes $A$ e $B$, estando relacionados ao substrato geológico da Formação Adamantina, com camadas espessas de material de arenitos finos a muito finos em colinas médias e convexas. Os latossolos vermelhos estão dispostos em baixas declividades e encostas mais amplas, e os argissolos se encontram em relevos de maiores declividades e encostas com menores extensões.

\subsection{Fator LS}

A maior área do Córrego Baguaçu é representada por colinas amplas, com topos extensos e vertentes de perfis retilíneos e convexos, apresentando declives suaves, com escoamento lento a médio, podendo ser adotadas 
práticas de controle da erosão, como terraços em nível e plantio em nível, entre outras. São áreas localizadas mais ao norte da bacia, próximas à foz.

As declividades da Bacia do Córrego Baguaçu estão concentradas nas classes entre $0 \%$ a $12 \%$ (Tabela 13 ).

Tabela 13 - Classes de declividade do Córrego Baguaçu.

\begin{tabular}{cc}
\hline Declividade em \% & Área em \% \\
\hline $0-3$ & 38,4 \\
$3-6$ & 28,5 \\
$6-12$ & 29,1 \\
$12-20$ & 3,9 \\
$20-40$ & 0,1 \\
\hline Total & 100,0 \\
\hline
\end{tabular}

Na porção sul da bacia, o relevo é mais dissecado nas nascentes, com maior entalhamento da drenagem. São relevos de colinas médias, interflúvios com topos aplainados e vertentes com perfis convexos a retilíneos.

De acordo com Lespch (2011), os argissolos, quando associados a latossolos, costumam se localizar em áreas mais declivosas. Na Figura 11 é possível visualizar essa afirmativa, onde a maior concentração de argissolos, cerca de $17,2 \%$ da bacia, está em declividades que variam de $6 \%$ a $12 \%$, e 0 latossolo vermelho concentra-se nas declividades mais baixas, de $0 \%$ a $3 \%$, com área de $24,7 \%$. 


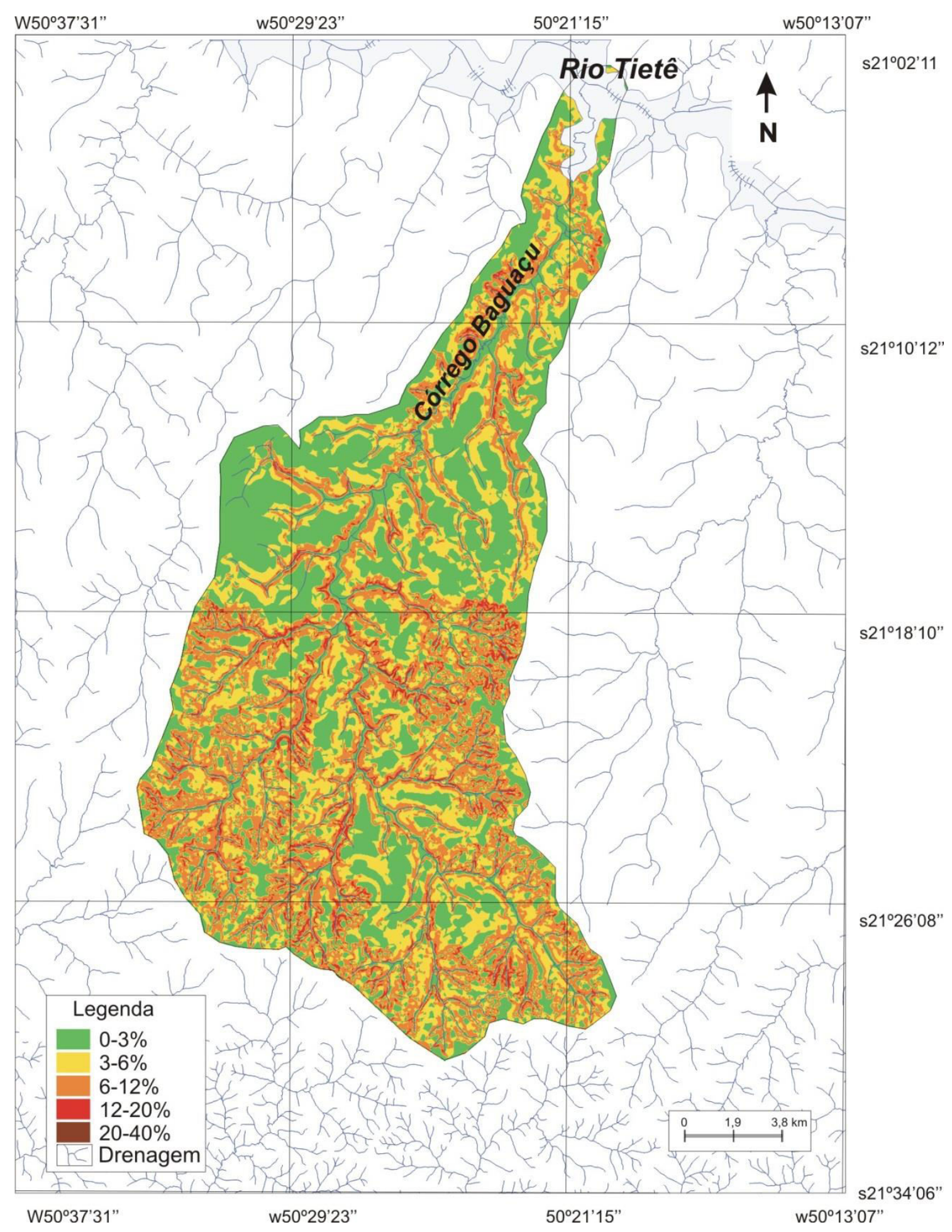

Figura 11 - Mapa de declividade do Córrego Baguaçu.

É possível notar que, nas áreas onde a declividade é maior (6\% a 12\%), o comprimento das encostas é menor e nas declividades mais baixas $10 \%$ a $6 \%$ ), o comprimento de rampa possui maiores extensões, sendo isso 
visivelmente identificado nas áreas das nascentes e na foz da bacia (Figura 12).

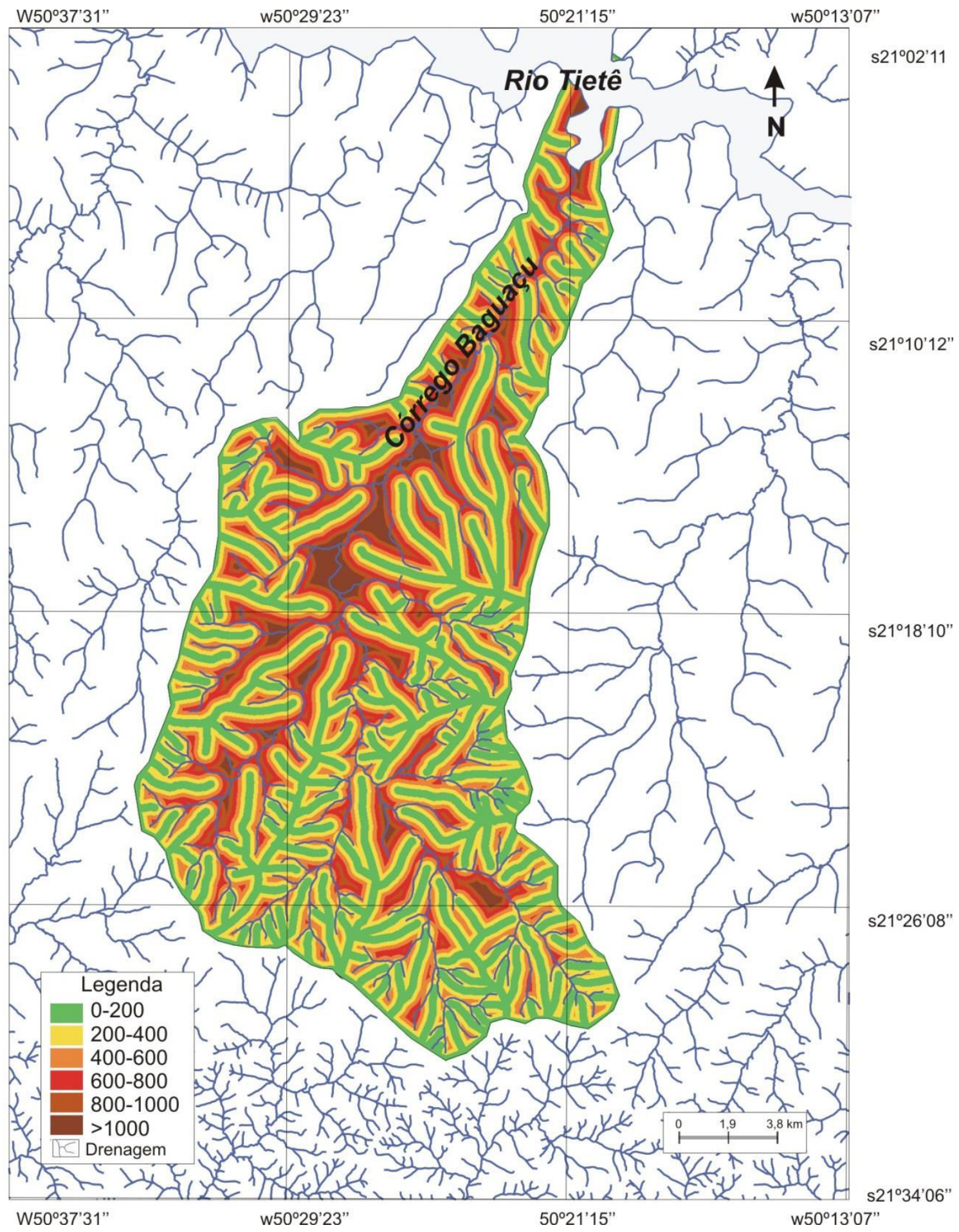

Figura 12 - Mapa de Comprimento de rampa do Córrego Baguaçu. 
O comprimento de rampa com maior área de representatividade na Bacia do Córrego Baguaçu está entre as classes de 0 a 200 m, com 32,7\% de sua área, seguindo-se com $28,4 \%$ para a classe de comprimento de rampa entre 200 a $400 \mathrm{~m}$ (Tabela 14).

Tabela 14 - Classes de comprimento de rampa do relevo do Córrego Baguaçu.

\begin{tabular}{lc}
\hline $\begin{array}{c}\text { Classes de } \\
\text { comprimento de } \\
\text { rampa }\end{array}$ & $\%$ \\
\hline $0-200$ & 32,7 \\
$200-400$ & 28,4 \\
$400-600$ & 19,8 \\
$600-800$ & 10,6 \\
$800-1000$ & 5,3 \\
$>1000$ & 3,1 \\
\hline Área total das \\
classes & 100,0 \\
\hline
\end{tabular}

Conforme a Tabela 15, os resultados mostram que, em mais da metade da área do Córrego Baguaçu (53,5\%), o fator topográfico varia entre 0 a 2 (adimensional), e 25,0\% está entre as classes classe >4 (adimensional).

Tabela 15 - Classes de fator topográfico do Córrego Baguaçu.

\begin{tabular}{cc}
\hline $\begin{array}{c}\text { Fator topográfico } \\
\text { em metros }\end{array}$ & $\%$ \\
\hline $0-2$ & 53,5 \\
$2-4$ & 21,5 \\
$>4$ & 25,0 \\
\hline Área total das \\
classes & 100 \\
\hline
\end{tabular}

A integração dos fatores $L$ e S para a geração do Fator Topográfico da EUPS (Figura 13) possibilita conhecer a influência da topografia na perda de solos, pois, quanto mais íngreme a encosta, maior velocidade de escoamento 
haverá, e quanto maior for o comprimento da rampa, maior será o volume de sedimentos transportados.

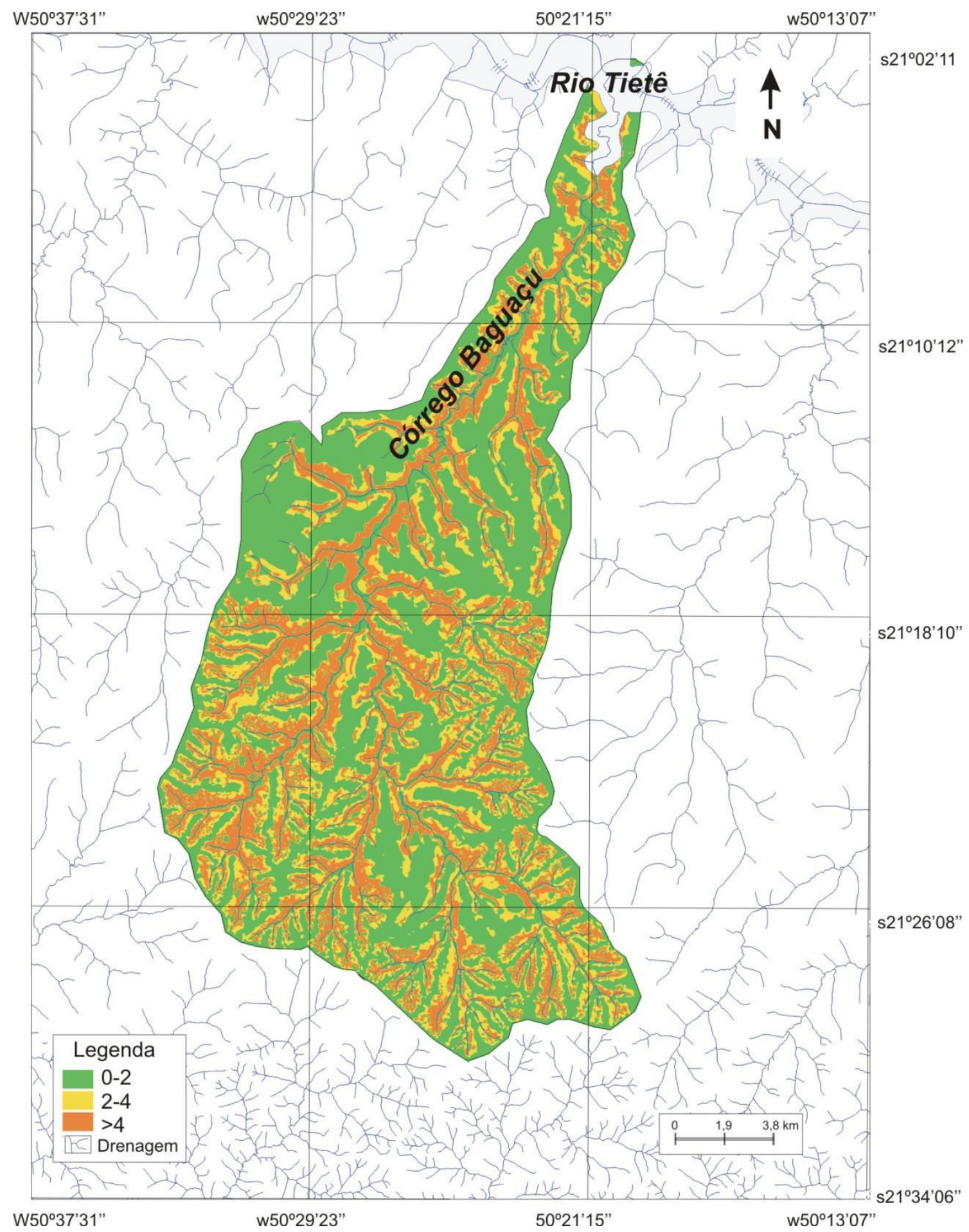

Figura 13 - Mapa de fator topográfico do Córrego Baguaçu. 
O mapa de fator topográfico (LS) na Bacia do Córrego Baguaçu apresenta maior distribuição das áreas entre os valores baixos de dissecação do relevo ( 0 a 2) e distribuição dividida entre valores médios (2 a 4) e altos de dissecação (>4). Em relação ao uso, em todas as classes de fator topográfico, há predomínio de uso de pastagem e de cana, sendo que, nas classes de $0 \mathrm{a}$ 4 , o uso é permitido para qualquer cultivo, necessitando de poucas práticas de manejo, ao contrário do cultivo em vertentes com dissecação média e declividades mais altas, onde são necessários maiores cuidados para plantio de cana, de milho e de soja, por exemplo, culturas que são praticadas na bacia.

As regiões de nascentes do Córrego Baguaçu, onde o relevo é ondulado a forte ondulado ( $6 \%$ a $12 \%$ de declividade), possuem alto Potencial Natural a Erosão, estando sob argissolos e ausência de vegetação ciliar nas áreas de nascentes. São áreas que necessitam de práticas conservacionistas adequadas, ou seja, conforme a recomendação de Machado, Vettorazzi e Xavier (2003), que sugerem a mudança do uso e ocupação das terras para proteção dos recursos hídricos, exigindo-se não somente a proteção e a conservação das áreas de mata ciliar, mas também devendo ser consideradas as áreas com encostas mais íngremes e de susceptibilidade natural aos processos erosivos, conservando a vegetação florestal e dispensando o uso agrícola intensivo, para que realmente ocorra a diminuição da produção e do transporte de sedimentos.

\subsection{Uso e ocupação do solo e Fator C}

As classes de uso do solo identificadas nas imagens ortorretificadas no Córrego Baguaçu foram: corpos d'água continentais, florestal, planície de inundação, pastagem, cana-de-açúcar, culturas anuais (milho e soja), eucalipto, solo exposto e áreas urbanizadas, como exposto na Tabela 16.

Os corpos d'água continentais representam áreas de drenagem, ou seja, rios e cursos d'água, assim como algumas represas artificiais, para abastecimento de animais ou para lazer. 
As áreas florestais representam as matas, localizadas como mata ciliar ao longo dos cursos d'água; mata capoeira ou vegetação natural remanescente em poucos fragmentos, representando apenas $5,2 \%$ da área da bacia.

Tabela 16 - Áreas das classes de uso e ocupação do solo.

\begin{tabular}{lc}
\hline \multicolumn{1}{c}{ Classe de uso } & Área (\%) \\
\hline Corpos d'água continentais & 0,9 \\
Florestal & 5,2 \\
Planície de Inundação & 6,9 \\
Pastagem & 41,4 \\
Cana-de-açúcar & 31,4 \\
Culturas anuais & 1,9 \\
Eucalipto & 0,3 \\
Solo exposto & 6,1 \\
Áreas urbanizadas & 5,8 \\
\hline Total & 100,0 \\
\hline
\end{tabular}

As planícies de inundação são áreas úmidas próximas aos cursos d'água, com vegetação rasteira ou típica, ocupando 6,9\% de área. Essas áreas estão relacionadas à presença de solos hidromórficos e onde há acúmulo de matéria orgânica superficial, dando uma coloração mais escura ao solo, que diminuiu a coloração nos sub-horizonte superiores. São áreas de deposição de sedimentos carreados das encostas (TAVARES, 1986).

Na classe pastagem ( $41,4 \%$ de área ocupada) incluem-se as diferentes variedades de ocorrência do pasto, seja o pasto sujo, pasto alto ou pasto baixo, em sua maioria, em declividades baixas, não oferecendo risco a susceptibilidade a erosão laminar, porém a falta de manejo, que provoca o pisoteio do gado, próximo aos córregos e em declividades mais acentuadas, provoca erosão em sulcos.

A cana-de-açúcar apresenta grandes glebas, desde áreas plantadas recentemente a plantios com maior densidade e tamanho. Representa a segunda maior classe de ocupação, com $31,4 \%$ de área. As áreas mais íngremes oferecem dificuldades quanto ao uso de máquinas agrícolas, sendo mais bem aproveitada por pastagem ou reflorestamento. 
As áreas de milho e soja (culturas anuais) representam poucas glebas, geralmente de formas geométricas, com plantios de menor ou maior densidade, dependendo do estágio de plantio. Ocupam apenas 1,9\% de área, distribuídas em todas as classes de declividade.

O eucalipto também apresenta formas geométricas nas áreas ocupadas, apresentando textura mais uniforme, alta densidade de biomassa e sombra nas imagens de satélite, características que permitiram sua identificação. Essa cultura apresenta área de apenas $0,3 \%$.

O solo exposto $(6,1 \%)$ indica áreas que estão sendo preparadas para algum plantio, na maioria dos casos, para a cana-de-açúcar ou para outra cultura, ou pode ser cana cortada, e isso, em ambos os casos permite a exposição do solo às intempéries climáticas, que favorecerão os processos erosivos.

Foram calculados valores de Fator $\mathrm{C}$ para as culturas cultivadas no Córrego Baguaçu, no ano de 2011, sendo elas: cana-de-açúcar, pastagem, milho, soja e eucalipto, considerando algumas práticas de manejo mais utilizadas na região.

Para a cana considerou-se o cultivo anual e cultivo de ano e meio sob preparo convencional, e a cana soca de ano e ano e meio sem queima.

Os resultados mostraram que, para a cultura da cana-de-açúcar de ano em preparo convencional e cana soca, o fator $C$ é maior durante o plantio $\mathrm{e}$ durante o crescimento e maturação. Para a cana planta de ano e meio, no primeiro ano de preparo convencional, o resultado de fator $C$ foi maior no estádio de resíduo, porém do segundo ano em diante, para a cana soca de ano e meio, os valores diminuíram, e o fator $\mathrm{C}$ foi maior no preparo do solo. $\mathrm{A}$ média do fator $C$ para a cana de açúcar é de 0,0168 .

Determinou-se o período de cultivo da pastagem para setembro, pois é início das chuvas na região, possibilitando melhor desenvolvimento vegetal. Para a cultura de pastagem, consideraram-se dois sistemas de cultivo, o de plantio e o de cultivo do segundo ano em diante. A razão de perda de solos é maior no estágio de plantio, porém o resultado do Fator $C$ é maior no estágio de crescimento e maturação devido ao início do período chuvoso. Para a 
pastagem de segundo ano em diante, os valores de Fator $\mathrm{C}$ são mais baixos, indicando maior eficiência da cobertura vegetal, com total de 0,0014.

Para o milho consideraram-se um tipo de cultivo, o milho contínuo com palha enterrada, que apresentou resultado do Fator $\mathrm{C}$ mais elevado no período de crescimento e maturação da cultura, com valor de 0,0307, ou seja, é o período de menor proteção que a cultura oferece ao solo.

A soja em cultivo convencional e contínuo apresentou maior proteção ao solo durante o estágio de resíduo com valor de 0,0007, e menor proteção durante o plantio, com 0,0235.

Para determinar os valores das classes de uso para o mapa do fator $\mathrm{C}$, confeccionado em SIG, definiu-se a média dos valores para as culturas e manejo da cana-de-açúcar, pastagem, o milho e soja (culturas anuais), obtendo valor médio de 0,0168 para cana, 0,0049 para a pastagem e 0,1418 para as culturas anuais. O solo exposto recebeu valor de 1,0, de acordo com VasquezFernandez et al. (1996) e a classe florestal de 0,0004 conforme Demarchi (2012), reproduzidos na tabela abaixo, assim como os valores para outras classes, como visto na Tabela 17:

Tabela 17 - Classes de uso e ocupação do Córrego Baguaçu e respectivo valor de Fator $\mathrm{C}$.

\begin{tabular}{lc}
\hline \multicolumn{1}{c}{ Classe de uso } & Valor de C \\
\hline Corpos d'água continentais & 0 \\
Florestal & 0,0004 \\
Várzea & 0 \\
Pastagem & 0,0049 \\
Cana-de-açúcar & 0,0168 \\
Culturas anuais & 0,1418 \\
Eucalipto & 0,000829 \\
Solo exposto & 1,0 \\
Áreas urbanizadas & 0 \\
\hline
\end{tabular}

Bertol (2001) obteve resultados de fator C para a soja com sistemas de preparo do solo aração + duas gradagens, escarificação + gradagem e semeadura direta, respectivamente: 0,1437, 0,0807 e 0,0455. 
O plantio de eucalipto para celulose no período de sete anos mostra que os valores tendem a diminuir do primeiro ano ao último, indicando que o eucalipto oferece boa proteção ao solo, minimizando os impactos da erosão.

O resultado do fator $\mathrm{C}$ do eucalipto para o Córrego Baguaçu de 0,000829 mostrou ser maior do que o utilizado por Vasquez-Fernandez et al. (1996), de 0,0001, porém mais baixo que o obtido por Martins (2005), de 0,0026 .

Os dados de fator $C$ da pastagem $(0,0049)$ e cana $(0,0168)$ no Córrego Baguaçu foram mais baixos do que os resultados analisados por Côrrea (2011), cujos valores do Fator $C$ foram: para pastagem, de 0,0100 e para canade-açúcar, de 0,1000. Oliveira (2004) utilizou os valores de 0,0075 para a pastagem e de 0,0500 para a cana; já os resultados obtidos por Cavalieri (1998) indicaram fator $C$ de 0,0010 para pastagem e de 0,1076 para cana-deaçúcar.

Na Figura 14 é mostrado o mapa de uso e ocupação do solo na bacia. 


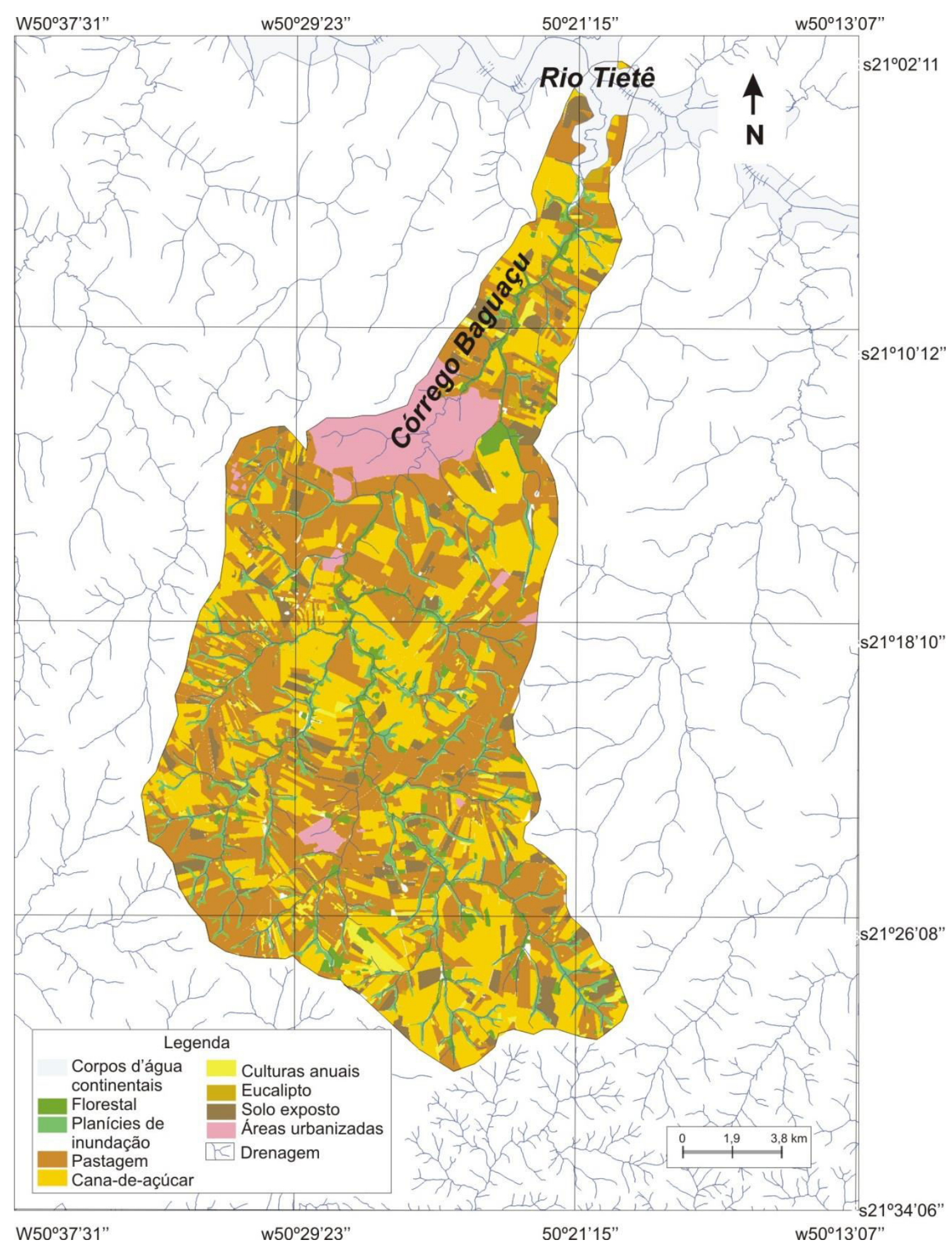

Figura 14 - Uso e ocupação do solo na Bacia do Córrego Baguaçu.

Demarchi (2012) considerou para a soja o fator $C$ de 0,2086 em cultivo convencional, sendo maior que o cultivo da soja na Bacia do Córrego Baguaçu, que, mesmo sob cultivo convencional, apresentou valor de 0,2116. 
A perda de solos para as áreas da planície de inundação e solos hidromórficos não receberam nenhum valor por serem áreas de deposição de sedimentos. As áreas urbanizadas também possui valor 0 por não serem objeto de estudos na EUPS, pois o objeto é a perda de solos em áreas agrícolas.

\subsection{Fator $P$}

Para determinar o Fator $\mathrm{P}$, foi feita análise das imagens ortorretificadas, onde foi possível dividir a bacia em duas classes condizentes às práticas conservacionistas, empregando valores de 0,5 para cultivo em contorno, ou seja, com curvas de nível e 1,0 para áreas em cultivo morro abaixo (Figura 15).

Aproximadamente $84,9 \%$ dos solos da Bacia do Córrego Baguaçu possuem práticas conservacionistas de prática em contorno, ou seja, curvas de nível, e 15,1\% apresentam plantio morro abaixo, sendo áreas ocupadas, em sua maioria, por pastagens e declividades encontradas entre as classes de $0 \%$ a $10 \%$ (Tabela 18).

Tabela 18 - Práticas conservacionistas da Bacia do Córrego Baguaçu.

\begin{tabular}{lc}
\hline \multicolumn{1}{c}{$\begin{array}{c}\text { Práticas } \\
\text { conservacionistas }\end{array}$} & Área (\%) \\
\hline Plantio em contorno & 84,9 \\
Plantio morro abaixo & 15,1 \\
\hline Total & 100,0 \\
\hline
\end{tabular}




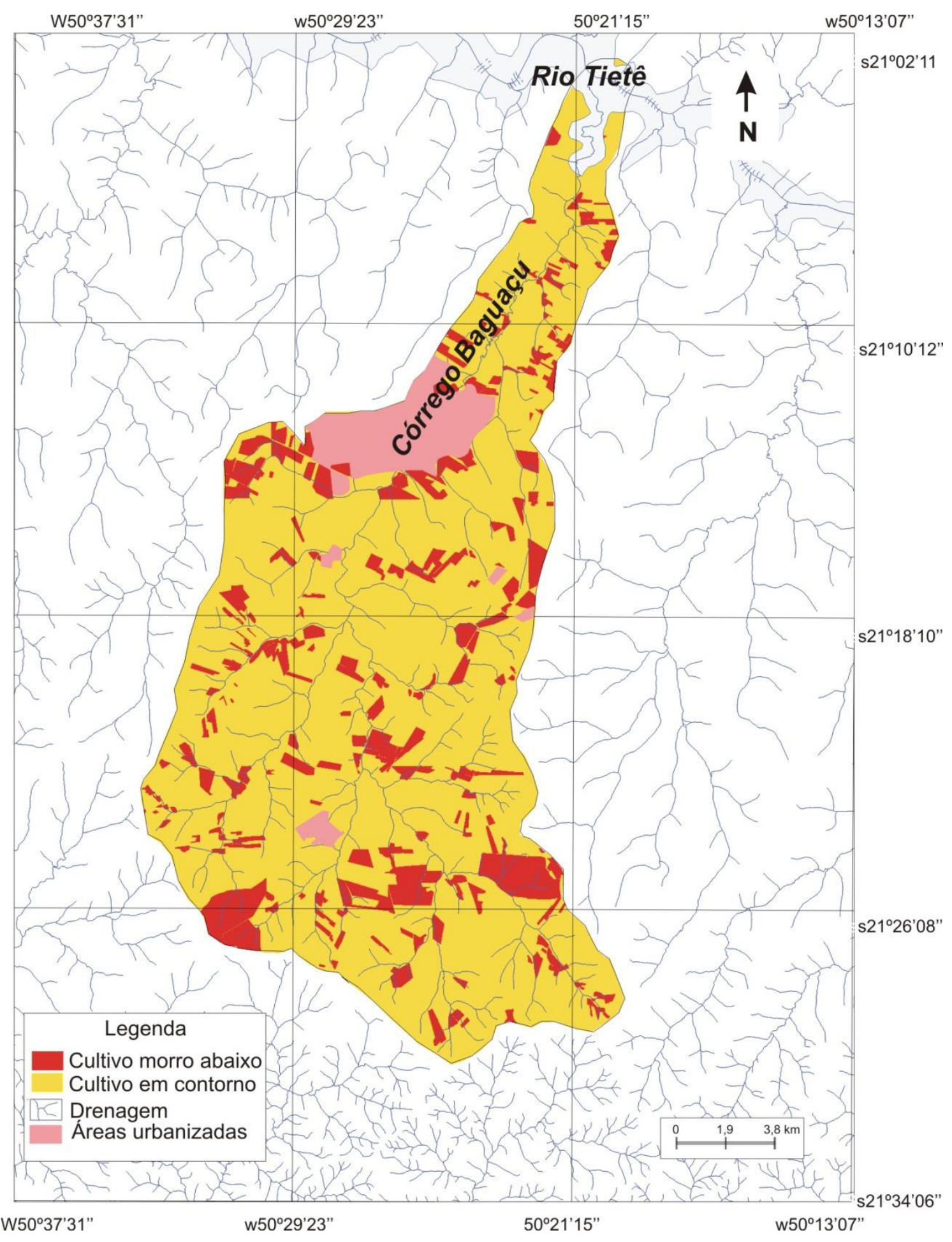

Figura 15 - Fator P da Bacia do Córrego Baguaçu.

Das áreas ocupadas por pastagens e lavouras de milho, soja e cana, grande parte delas oferece curvas de nível, sendo que as pastagens apresentam a maior área sem práticas conservacionistas. 


\subsection{Potencial Natural a Erosão - PNE}

De acordo com os resultados alcançados, na Bacia do Córrego Baguaçu, a classe de Potencial Natural a Erosão que predomina é a classe muito baixa, compreendida entre o intervalo de 0 a $120 \mathrm{t}$ (ha.ano) com 31,4\% de área, dispostas sobre Latossolo Vermelho e com índice de fator topográfico de 0 a 2, em sua maioria, localizadas na porção superior das vertentes (Tabela 19).

Tabela 19 - Classes de PNE e área ocupada na Bacia do Córrego Baguaçu.

\begin{tabular}{cc}
\hline $\begin{array}{c}\text { Classes de Perda de } \\
\text { Solo em t/ha.ano }\end{array}$ & Área em \% \\
\hline Muito baixo $(0-120)$ & 31,4 \\
Baixo $(120-250)$ & 11,0 \\
Médio $(250-500)$ & 16,4 \\
Alto $(500-700)$ & 10,5 \\
Muito alto $(>700)$ & 30,7 \\
\hline Total & 100 \\
\hline
\end{tabular}

A classe com média perda de solos (250 a 500 tha.ano) representa $16,4 \%$ da bacia, estando localizado quase igualmente sob Latossolo Vermelho e Argissolo, nas declividades entre $2 \%$ a $10 \%$.

A segunda classe de maior área está representada na classe muito alta, ou seja, apresenta perda de solo com mais de 700 t/ha.ano com 30,7\% de área. São áreas dispostas nas médias vertentes com declividades, em sua maioria, na classe de $5 \%$ a $10 \%$, e principalmente no alto curso da bacia, onde se localizam argissolos.

De maneira geral, a bacia possui média predisposição natural à erosão, com maior vulnerabilidade nas cabeceiras de drenagem do Córrego, onde há presença de solos mais vulneráveis e maiores declividades (Figura 16).

Stein et al. (1987) afirmam que há interação entre os fatores, mas existem dominâncias entre um fator sobre outro, porém não se deve excluir a 
influência dos demais. Em relação ao potencial natural a erosão, o índice de erodibilidade (fator K) junto com o fator topográfico (LS), juntos são fatores importantes, pois valores baixos ou altos são sempre deles oriundos, portanto merecem controle efetivo por parte da declividade $(S)$ e da erodibilidade $(K)$, isso relativamente ao comprimento de rampa $(\mathrm{L})$ e à erosividade $(R)$.

Pinto (1991), por meio de correlação e coeficiente de determinação, concluiu que a declividade foi o fator de maior influência nos altos valores de PNE, isso seguido de valores mais elevados de erodibilidade, que, no caso, também eram solos podzolizados (argissolos).

Foi constatada influência do Fator Topográfico no mapa de PNE e dos solos do Córrego Baguaçu, onde as áreas com declividade média, na classe de $5 \%$ a 10\%, passaram a ser áreas de PNE muito alto, em áreas de argissolos. 0 mesmo acontece com as declividades baixas, de $2 \%$ a $5 \%$, que foram minimizadas para as classes de PNE muito baixo e baixo, estando sob Latossolos Vermelho. Stein et al. (1987) também concluíram que os valores máximos e minímos do PNE são sempre determinados pelos fatores $\mathrm{K}$ e LS, com pouca ou nenhuma interferência do fator $R$ quando analisaram o PNE na Bacia Hidrográfica dos Rios Peixe-Paranapanema, no estado de São Paulo. 


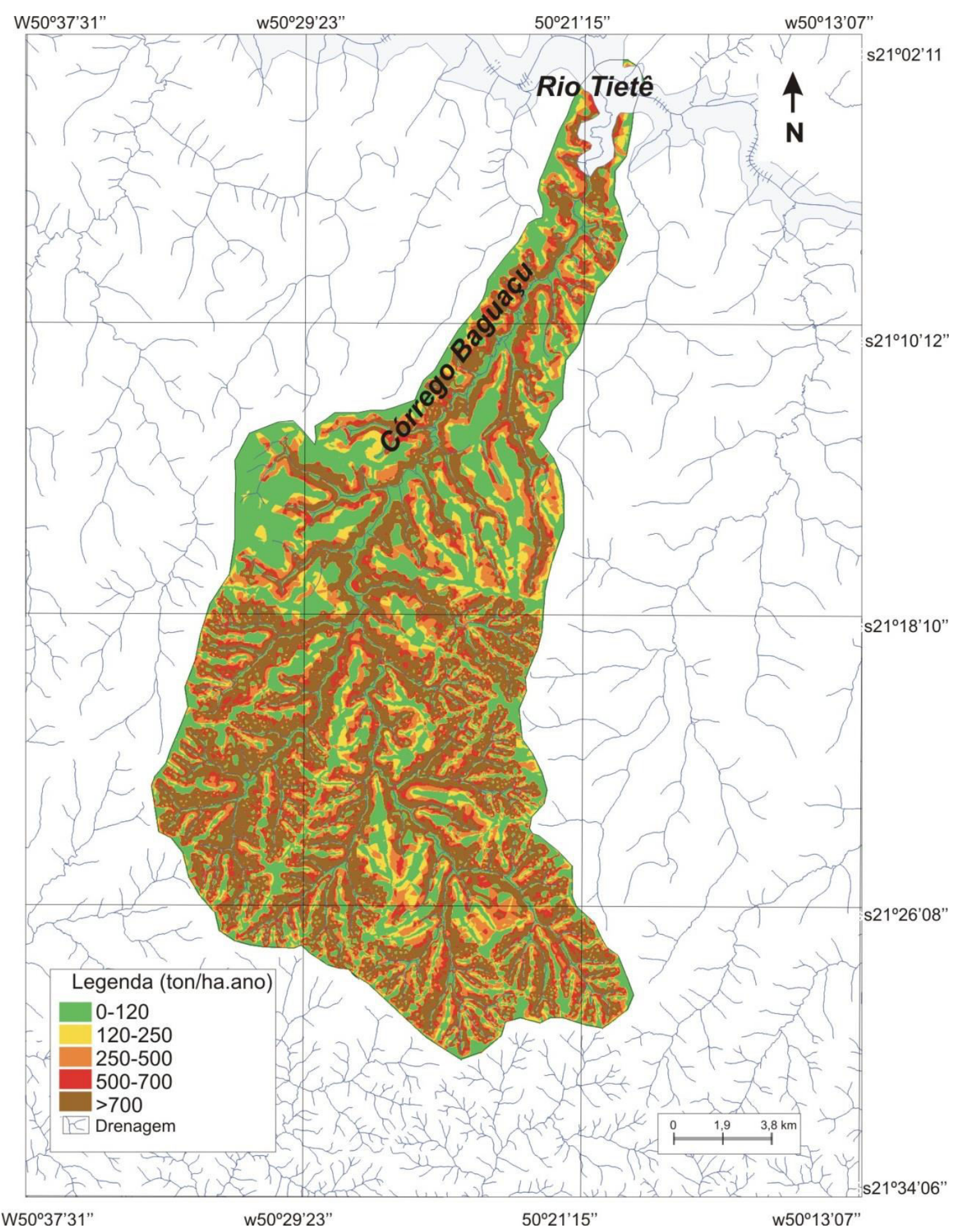

Figura 16- Potencial Natural a Erosão - PNE do Córrego Baguaçu.

5.7 Estimativa de erosão laminar em função de fatores de ocupação do Córrego Baguaçu/SP. 
Por meio do fator $\mathrm{CP}_{\text {atual, }}$ que fornece resultados do uso e práticas atuais, e do fator $\mathrm{CP}_{\text {tolerável, }}$ indicador dos elementos da paisagem responsáveis pela erosão, foi possível analisar a diferença entre os dois fatores.

De acordo com Bueno e Stein (2004), os resultados não devem ser estimados de forma quantitativa, mas, sim, qualitativa, pois nas áreas de glebas negativas pode haver manifestação de processos erosivos, assim como nas glebas positivas pode não haver erosão. Os resultados devem ser tratados apenas para avaliações localizadas (STEIN et al., 1987).

Em valores numéricos, negativos e positivos, é possível indicar as classes de uso e ocupação em que se manifestam de maneira maior ou menor os processos erosivos (Tabela 20).

Tabela 20 - Discordância positiva e negativa em relação ao uso e ocupação do Córrego Baguaçu.

\begin{tabular}{lccc}
\hline \multicolumn{1}{c}{ Uso } & $\begin{array}{c}\text { Adequado } \\
(<\mathbf{0})\end{array}$ & $\begin{array}{c}\text { Pouco } \\
\text { adequado } \\
(\mathbf{0 - 0 . 0 9 )}\end{array}$ & $\begin{array}{c}\text { Inadequado } \\
(>\mathbf{0 . 0 9 )}\end{array}$ \\
\hline Corpos d'água continentais & 0,4 & 0,5 & 0,0 \\
Florestal & 3,8 & 1,4 & 0,0 \\
Planície de inundação & 5,7 & 1,1 & 0,0 \\
Pastagem & 32,0 & 9,4 & 0,0 \\
Cana-de-açúcar & 19,3 & 12,1 & 0,0 \\
Culturas anuais & 0,2 & 1,6 & 0,2 \\
Eucalipto & 0,0 & 0,0 & 0,0 \\
Solo exposto & 0,1 & 0,0 & 6,0 \\
Áreas urbanizadas & 4,2 & 1,7 & 0,0 \\
\hline
\end{tabular}

Cerca de 27,9\% das glebas encontram-se em situação pouco adequada (positiva para erosão laminar), e apenas $6,3 \%$ são inadequadas. A ocupação adequada (negativa para erosão laminar) corresponde a $65,8 \mathrm{~km}^{2}$ da área da Bacia do Córrego Baguaçu.

As áreas adequadas ao uso estão relacionadas, em sua maioria, ao latossolo vermelho-escuro isso associado ao relevo de colinas amplas, com longas encostas e baixa declividade. Quanto às áreas referentes a pouca adequação de uso, grande parte delas está localizada nas áreas de relevo com declive maior e encostas de menor extensão. Os maiores níveis de áreas 
inadequadas estão relacionados ao uso e práticas conservacionistas (Figura 17).

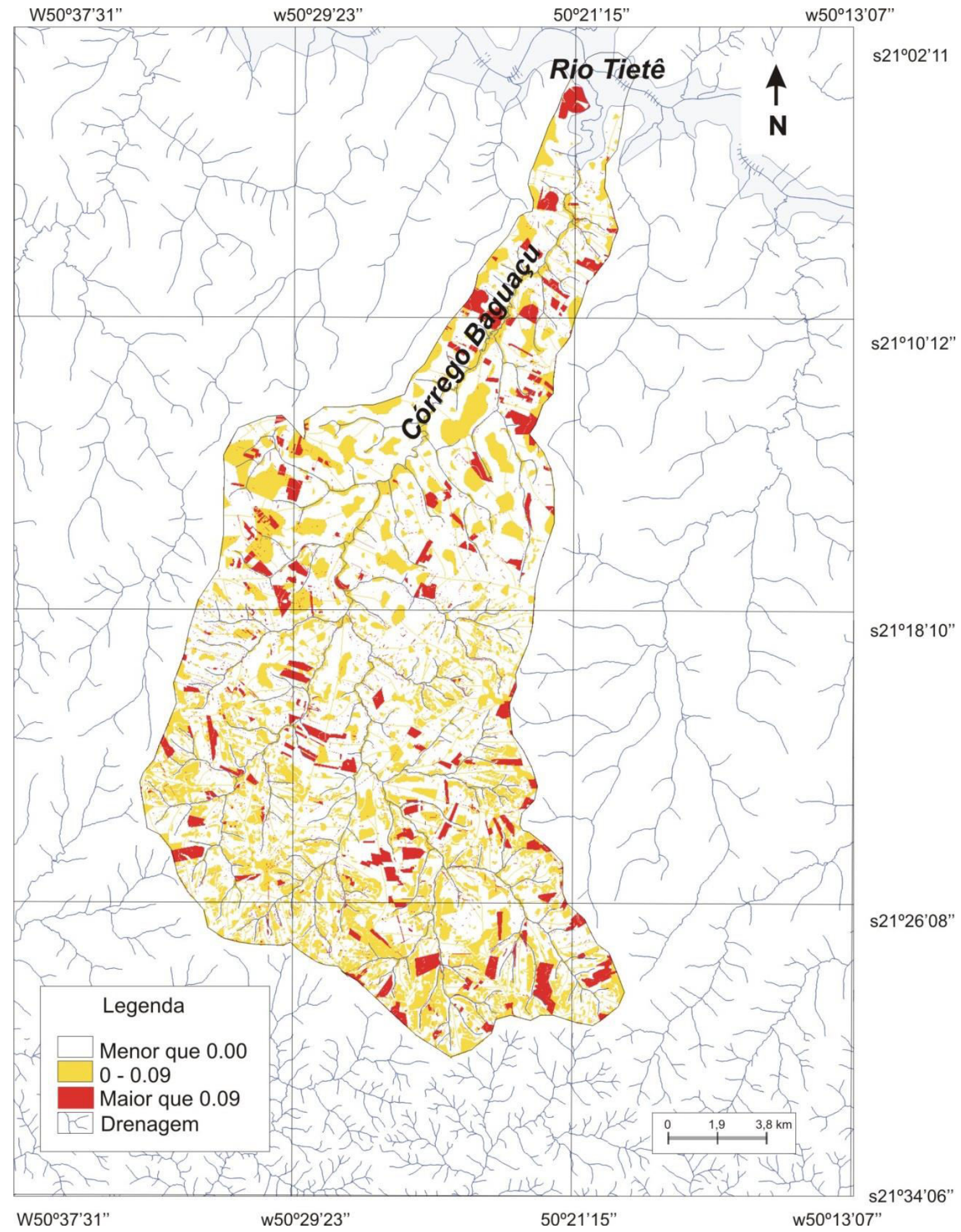

Figura 17 - Expectativa quanto à erosão laminar na Bacia do Córrego Baguaçu. 
O cruzamento do mapa de expectativa de erosão laminar em função dos fatores de ocupação e do uso do solo na bacia permitiu indicar que $32 \%$ da pastagem ocupada e 19,3\% da cana possuem uso adequado, ou seja, a expectativa a erosão é quase nula. Porém, $9,4 \%$ de área ocupada pelo pasto e $12,1 \%$ da cana são áreas pouco adequadas. A indicação da pastagem é resultado da ausência de práticas conservacionistas em algumas áreas plantadas. A cana-de-açúcar possui a maior área de uso pouco adequada na bacia, apesar de serem mantidas curvas de nível. Nesse caso, o motivo de o resultado da erosão ser alto é o cultivo em locais com argissolos e/ou declividades que variam entre $0 \%$ a $12 \%$. Em contrapartida, as classes de uso florestal e de planícies de inundação possuem maior proteção contra os processos erosivos, o que reforça o papel importante que a vegetação possui contra os processos erosivos.

\subsection{Equação Universal de Perda de Solos (EUPS)}

Utilizando a EUPS, equação que relaciona os fatores naturais e antrópicos envolvidos no sistema da Bacia do Córrego Baguaçu, foi possível estimar a perda de solo por erosão laminar, indicando que a classe de maior perda de solo por erosão laminar para o ano de 2011 corresponde a de 0 a 3 t/ha.ano, com 70,1\% da área da bacia (Tabela 21).

Tabela 21 - Perda de solos em t/ha.ano da Bacia do Córrego Baguaçu

\begin{tabular}{cc}
\hline $\begin{array}{c}\text { Perda de solos } \\
\text { (t/ha.ano) }\end{array}$ & $\begin{array}{c}\text { Área } \\
\%\end{array}$ \\
\hline $0-3$ & 70,1 \\
$3-5$ & 9,6 \\
$5-10$ & 9,2 \\
$10-20$ & 3,6 \\
$20-50$ & 1,4 \\
$50-100$ & 1,3 \\
$>100$ & 4,9 \\
\hline Total & 100,0 \\
\hline
\end{tabular}


A mata, áreas de inundação e eucalipto, com menores valores de Fator C (0,0004, 0 e 0,000829, respectivamente), estão exclusivamente inseridos na classe mais baixa de perda de solos, de 0 a 3 t/ha.ano.

As perdas de solos por erosão de 0 a 3 tha.ano concentram-se nas porções mais altas das vertentes, áreas de interflúvios com topos aplainados; e no segmento da baixa vertente, próximas aos cursos d'água, onde a perda de solos é baixa ou quase nula, por serem áreas de deposição.

Nas declividades entre $3 \%$ a $12 \%$, há maiores perdas de solos, variando desde 0 a 20 t/ha.ano. São áreas ocupadas, em sua maioria, por pastagem e cana, que, associadas a altas declividades e a erosividade das chuvas, principalmente entre os meses de outubro e março, nelas se acentuam o escoamento superficial e a remoção de sedimentos para as planícies de inundação. No alto curso da bacia, o caso ainda é agravado pela associação aos argissolos, pois são áreas que possuem tendência de remoção da camada superficial do solo pela enxurrada e dificuldades de infiltração da água, isso devido à diferenciação textural entre horizontes $\mathrm{A}$ e $\mathrm{B}$ textural.

A diminuição da permeabilidade dos solos é melhor visualizada a montante da bacia, nas cabeceiras de drenagem com maior dissecação do relevo, sob argissolos, que possuem maior densidade de drenagem devido às variações granulométricas da litologia do grupo Bauru, dificultando a infiltração (PEREZ FILHO, 1977 e TAVARES, 1986).

Nas classes que variam de 3 a 5 t/ha.ano há ocupação de pasto, predominantemente; a segunda ocupação é a de cana. Algumas áreas de culturas anuais e solo exposto estão presentes nas áreas com perdas de solos entre 5 a >100 t/ha.ano, devido ao maior valor de fator $\mathrm{C}$ para tais usos (Figura 18). 


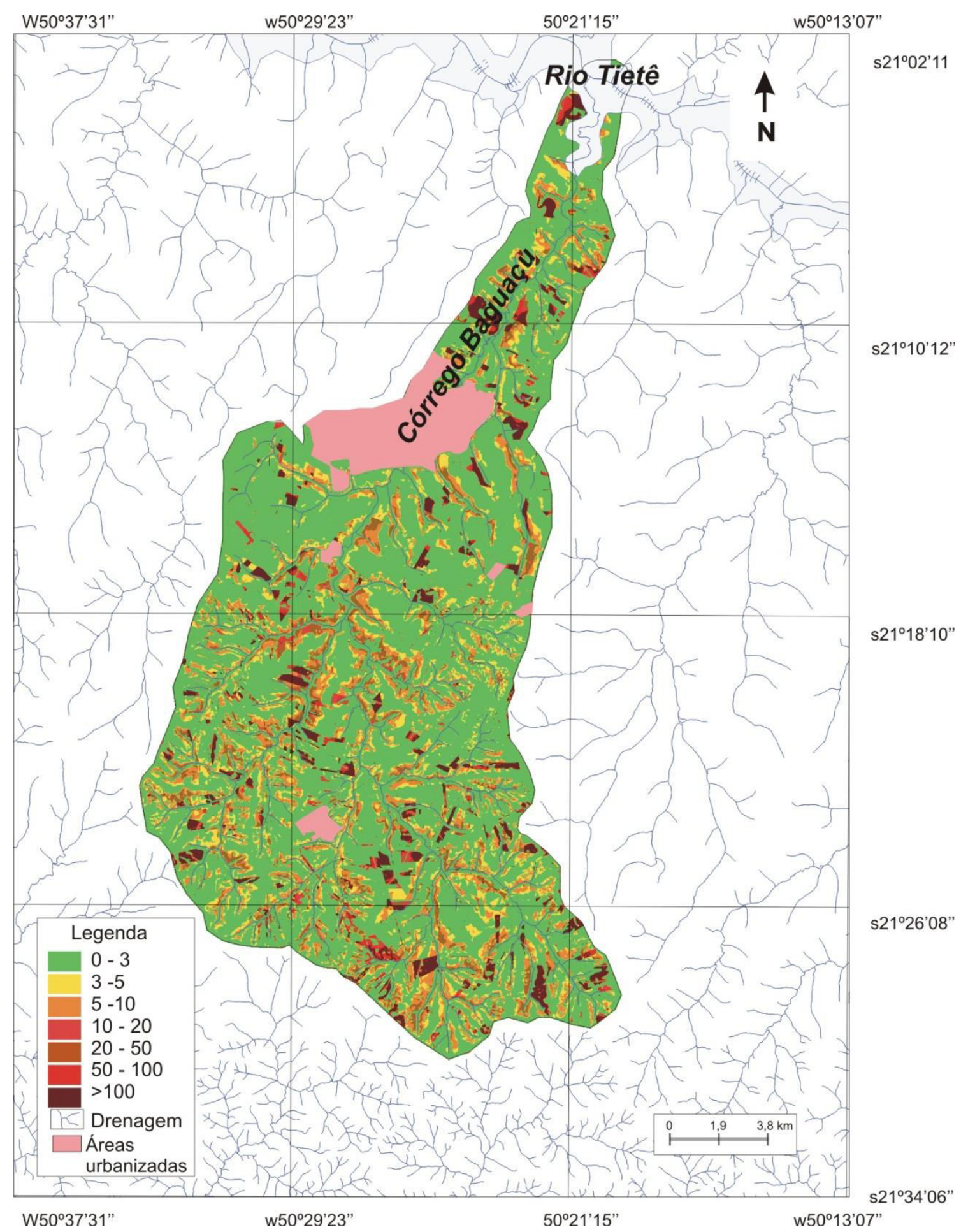

Figura 18 - Perda de solos por erosão na Bacia do Córrego Baguaçu em 2011.

Além do fator $\mathrm{C}$ do solo exposto, as áreas com plantio morro abaixo também é responsável pela perda de solo com mais de 100 t/ha.ano, por estarem distribuídas em declividades que variam, em sua maioria, nas classes de $0 \%$ a $3 \%$ e $6 \%$ a $12 \%$ de declividade (Tabela 22 ). 
Tabela 22 - Áreas em \% de perda de solos associadas ao uso e ocupação do solo na Bacia do Córrego Baguaçu.

\begin{tabular}{ccccccccc}
\hline \multirow{2}{*}{ Classes de uso } & \multicolumn{7}{c}{ \% de perda de solo em t/ha.ano } \\
\cline { 2 - 9 } & $0-3$ & $3-5$ & $5-10$ & $10-20$ & $20-50$ & $50-100$ & $>100$ \\
\hline Corpos d'água & 0,9 & 0 & 0 & 0 & 0 & 0 & 0 \\
continentais & 5,2 & 0 & 0 & 0 & 0 & 0 & 0 \\
Florestal & 6,9 & 0 & 0 & 0 & 0 & 0 & 0 \\
Planícies de & 33,6 & 5,1 & 2,4 & 0,3 & 0 & 0 & 0 \\
inundação & 16,5 & 4,7 & 6,8 & 3,0 & 0,4 & 0 & 0 \\
Pastagem & 0,4 & 0, & 0,1 & 0,2 & 0,5 & 0,5 & 0,2 \\
Cana-de-açúcar & 0,3 & 0 & 0 & 0 & 0 & 0 & 0 \\
Culturas anuais & 1,3 & 0 & 0 & 0,1 & 0,4 & 0,6 & 3,6 \\
Eucalipto & 5,8 & 0 & 0 & 0 & 0 & 0 & 0 \\
Solo exposto &
\end{tabular}

Os resultados da EUPS mostram que, em relação ao limite tolerado de perda de solos para o Argissolo e para o Latossolo, grande parte de área ocupada pela bacia está abaixo da tolerância considerada. Quando considerado que o Argissolo, de acordo com Bertoni e Lombardi Neto (2012), possui tolerância de 4,5 t/ha, cerca de $35 \%$ do uso ocupado no argissolos possui perda de solos abaixo da sua perda permissível e para o Latossolo Vermelho, que possui maior limite de tolerância, 15 t/ha, aproximadamente $39,3 \%$ de sua área corresponde a perdas na classe mais baixa, de 0 a 3 t/ha.ano (Tabela 23).

Tabela 23 - Relação de perda de solos com os solos da Bacia do Córrego Baguaçu.

\begin{tabular}{ccc}
\hline \multirow{2}{*}{$\begin{array}{c}\text { Perda de solo em } \\
\text { t/ha.ano }\end{array}$} & \multicolumn{2}{c}{ Área ocupada por solos (\%) } \\
\cline { 2 - 3 } & $\begin{array}{c}\text { Argissolo } \\
\text { (tolerância 4,5 } \\
\text { t/ha) }\end{array}$ & $\begin{array}{c}\text { Latossolo } \\
\text { Vermelho } \\
\text { (tolerância } \\
\mathbf{1 5 , 0} \text { t/ha) }\end{array}$ \\
\hline $0-3$ & 30,8 & 39,3 \\
$3-5$ & 5,4 & 4,2 \\
$5-10$ & 5,0 & 4,1 \\
$10-20$ & 1,9 & 1,8 \\
$20-50$ & 0,7 & 0,7 \\
$50-100$ & 0,7 & 0,6 \\
$>100$ & 2,4 & 2,4 \\
\hline
\end{tabular}


O solo exposto foi classificado com alto potencial de erosão laminar, isso devido à falta de cobertura vegetal, lembrando que a maioria das áreas com solo exposto são áreas que estão sendo preparadas para o plantio, provavelmente para cana.

Se considerarmos que a pastagem ocupa $41,4 \%$ da bacia, com $9,4 \%$ de ocupação pouco adequada e $32 \%$ de área de ocupação adequada, enquanto que a cana-de-açúcar ocupa $31,4 \%$ da bacia e $12,1 \%$ da ocupação é considerada pouco adequada e 19,3\% adequada, pode-se concluir que a cana produz maior carga de sedimentos erosivos se comparada à pastagem. Porém, quando relacionamos o uso às perdas de solos (EUPS), é possível ver que a cana e a pastagem são eficientes na proteção do solo, mantendo a perda de solos por erosão laminar nas classes mais baixas, entre 0 a 3 t/ha.ano.

Por serem predominantes na bacia, o pasto e a cana também são as classes que representam maior adequação em relação à expectativa de maior erosão laminar em função dos fatores antrópicos, porém Stein et al. (1987) chamam a atenção para o fato de que, mesmo em áreas de discrepância negativa ou nula, pode haver processos erosivos devido à cobertura precária do terreno, como em pastos e em culturas temporárias e perenes.

As culturas anuais (milho e soja) representam apenas $11,7 \%$ de área da bacia e apresentaram perdas de solo nas classes mais altas consideradas neste estudo, indicando uma perda de $2 \%$ do total de perda de solos.

Os Fatores $\mathrm{C}$ e $\mathrm{P}$ de uso e práticas conservacionistas são responsáveis pela redução dos valores de perdas de solo por erosão da EUPS, diferentemente do fator LS no PNE, que influencia no aumento de perda de solos por erosão. De acordo com os resultados, o PNE na classe de 0 a 120 t/ha.ano possui $31,4 \%$ de área, e $30,7 \%$ ocupa área na classe muito alta do PNE (>700 t/ha.ano), enquanto que, na EUPS, a classe de maior representatividade é a classe mais baixa, de 0 a 3 t/ha.ano, com $70,1 \%$ de área.

Demarchi (2012) chegou à mesma conclusão ao analisar que, áreas de PNE baixo e sem cobertura vegetal, apresentavam altos índices de perda de 
solos, enquanto que em declives acentuados e solos altamente suscetíveis, neles a erosão, a perda de solos era menor devido ao uso de práticas conservacionistas.

Abaixo são mostrados alguns registros fotográficos da Bacia do Córrego Baguaçu, como na Figura 19 e 20, onde a paisagem apresenta colinas amplas e vertentes de perfis retilíneos e convexos com altitudes entre 380 a 460 e declividades que variam entre $0 \%$ a $12 \%$. As amplas várzeas, que se situam entre 330 a $380 \mathrm{~m}$ e declividade média entre $0 \%$ a 6\%, são utilizadas para pastagem e, ao fundo, para cana-de-açúcar, notando a ausência de mata ciliar (Figura 19 e 20).
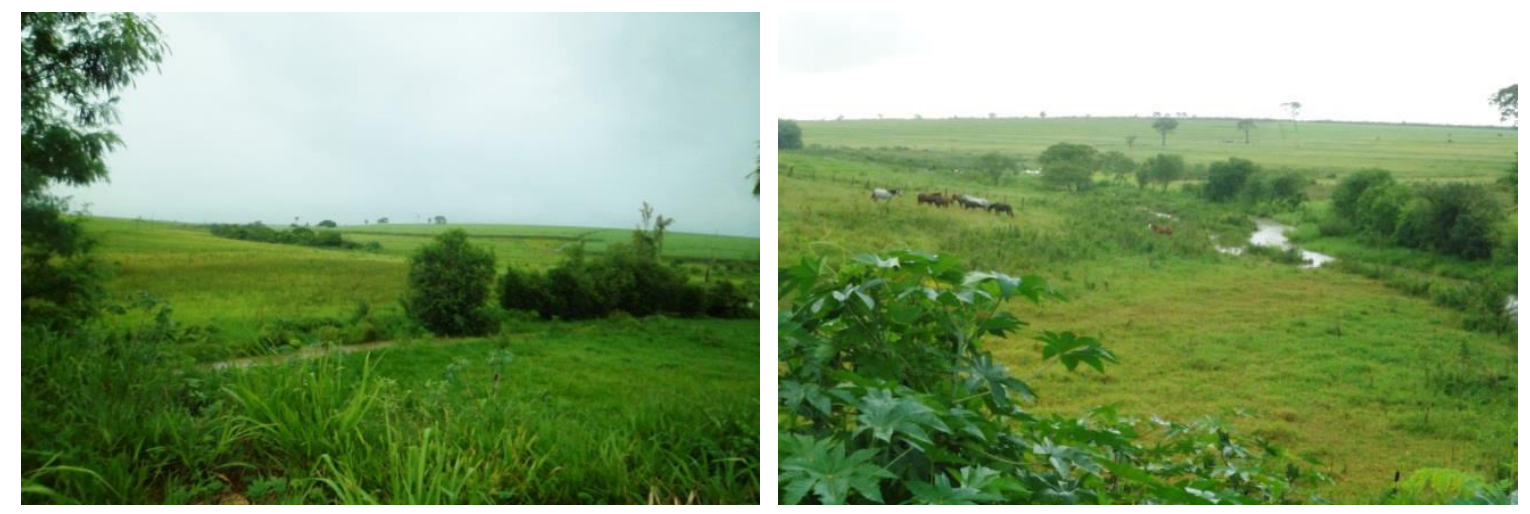

Figura 19 e 20 - Corte da estrada sob afluente na margem esquerda do Córrego Baguaçu. S21¹5'03.89" W50²8'18.51".

A Figura 21 mostra um canal afluente do Córrego Baguaçu com cicatrizes de erosão em suas margens provenientes do desmatamento e de pisoteio contínuo do gado que compacta os solos e causa dificuldades na infiltração da água, ocorrendo remoção e transporte de sedimentos para o canal fluvial.

A Figura 22 mostra o afluente do Córrego Baguaçu canalizado e que atravessa a área urbana de Araçatuba. 

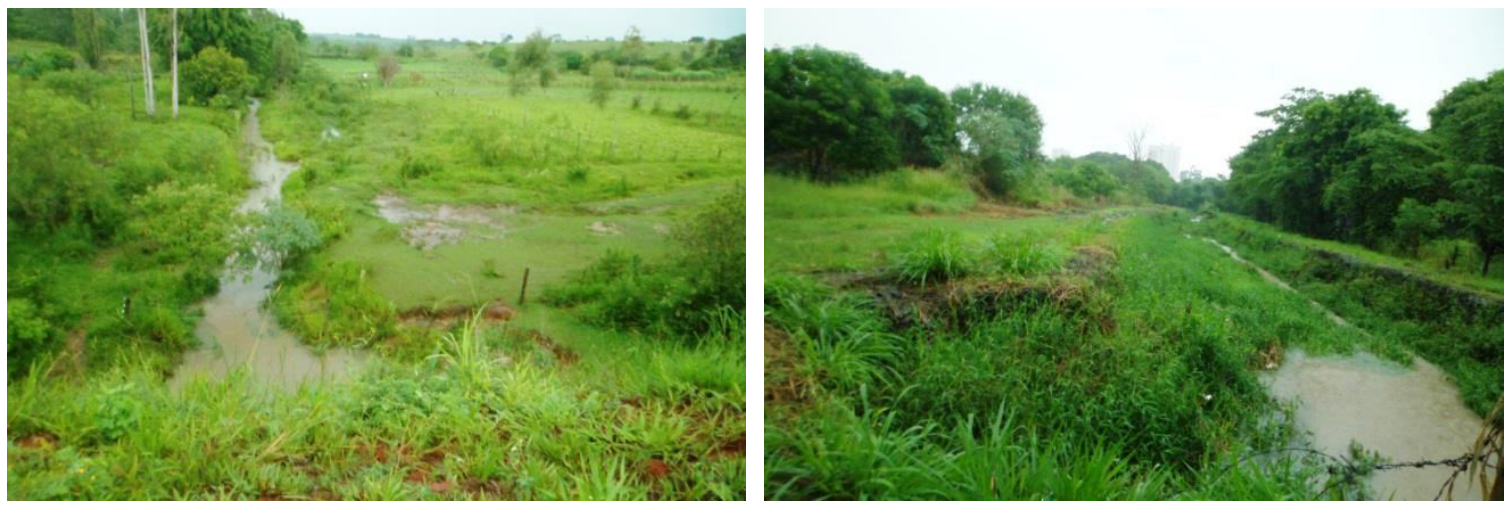

Figura 21 - Afluente Córrego Baguaçu S21ำ' $36.24^{\prime \prime}$ W502' $18.06^{\prime \prime}$.

Figura 22 - Curso d'água canalizado em área urbana $\mathrm{S} 21^{\circ} 13^{\prime} 41.98^{\prime \prime}$ W50²5'34.62".

Poucos trechos de cursos d'água possuem mata ciliar, sendo identificados alguns trechos, como na Figura 23, que focaliza um afluente à esquerda do Córrego Baguaçu e no Parque Ecológico Baguaçu (PEBA), localizado na área urbana de Araçatuba, criado em 1988 (Figura 24).
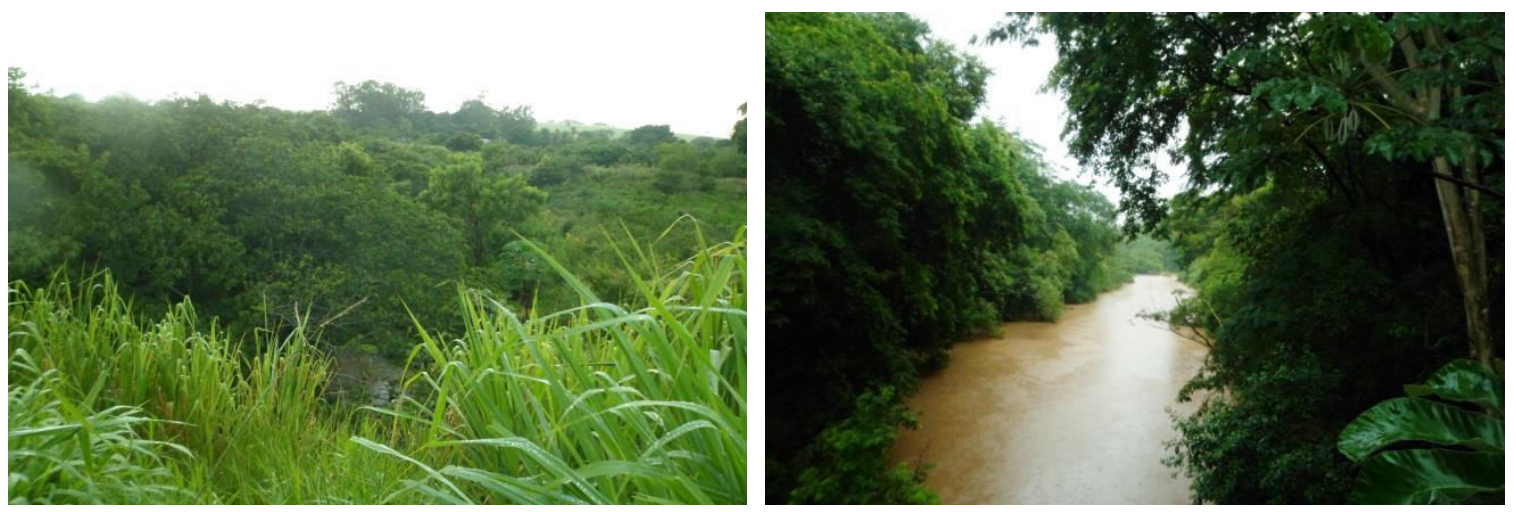

Figura 23 - Afluente do Córrego Baguaçu S21018'30.03"' W50²8'00.61".

Figura 24 - Parque Ecológico Baguaçu S21'13'19.61" W50²5'43.80".

Na Figura 25 encontra-se o levantamento das feições erosivas por meio de análise de fotografias ortorretificadas. 


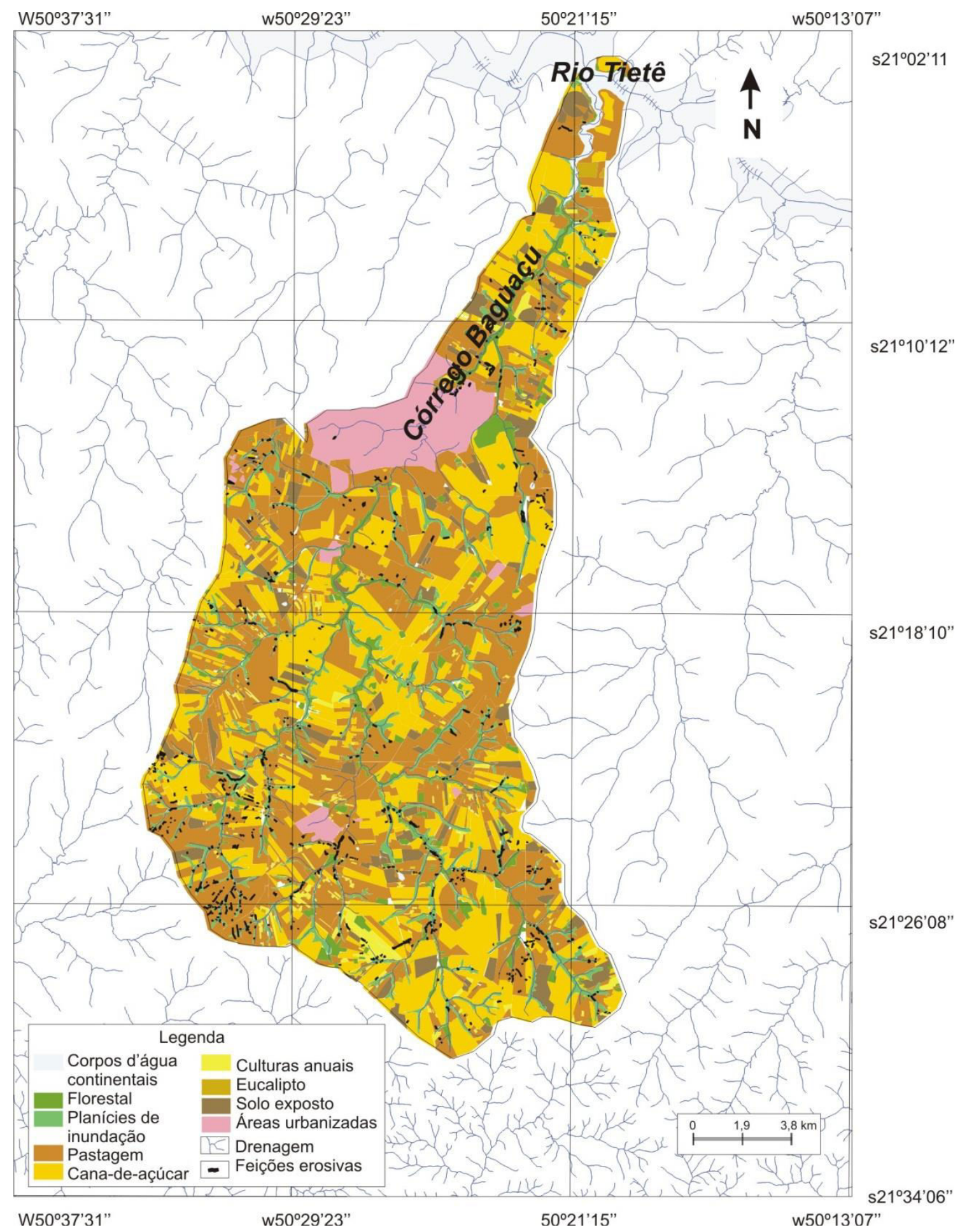

Figura 25 - Feições erosivas na Bacia do Córrego Baguaçu em 2011.

As feições erosivas de ordem laminar são resultado do escoamento difuso da água, de difícil visualização, sentidas apenas quando as raízes de plantas estão expostas, por exemplo. A erosão linear é de fácil percepção, 
ocorrendo em único fluxo concentrado de água e produzindo formas em grandes escalas, como ravinas e voçorocas.

O levantamento de feições erosivas (sulcos) na Bacia do Córrego Baguaçu indica que houve retirada de cobertura vegetal ou, se não houve retirada, então indica a precariedade da cobertura original. Isso propicia maior velocidade ao escoamento superficial da água, sendo observados sulcos junto a trilhas e a caminhos para plantio; também há sulcos no caminho feito pelo gado próximo a áreas de planícies de inundação ou junto aos cursos d'água; e, predominantemente, há sulcos em áreas de pastagem e de cana-de-açúcar. Os usos com maiores feições erosivos registrados foram o pasto, a cana-deaçúcar e as planícies de inundação, respectivamente. 


\section{CONCLUSÕES}

Apesar das críticas a modelos empíricos de estimativas de perdas de solos por erosão, como a EUPS, o resultado aplicado na Bacia do Córrego Baguaçu mostrou-se satisfatório diante dos objetivos e das hipóteses propostos no início do trabalho. De uso relativamente fácil, é resultado da interação de variáveis físicas e antrópicas, que possibilitam a identificação de áreas com menor e maior vulnerabilidade aos processos erosivos, indicando os possíveis fatores relacionados a tais eventos. O modelo ainda permitiu a indicação de algumas melhorias que visem planejamentos futuros, de forma a minimizar os impactos relacionados aos processos erosivos agrícolas. Vale frisar que 0 resultado de tal modelo é uma estimativa e seu uso só prediz erosão de origem laminar, excluindo formas de erosão mais avançadas.

A estimativa de perda de solos por erosão na Bacia do Córrego Baguaçu concentra-se em 0 a 3 t/ha.ano, ou seja, a expectativa de erosão é baixa, porém esses resultados foram encontrados, em grande parte, em planícies de inundação, que são áreas de deposição de sedimentos, e em áreas com cultivo de eucalipto e vegetação nativa. Áreas com maiores perdas de solos estão, na maioria, nas médias encostas de relevo de colinas médias e declividades maiores, associados aos argissolos provenientes das camadas espessas de arenitos finos da formação Adamantina do Grupo Bauru.

O papel do uso do solo e as práticas conservacionistas da EUPS são elementos decisivos, que atenuaram significadamente as perdas de solo resultado das condições intrínsecas (PNE) da Bacia do Córrego Baguaçu, resultado que reforça a importância do uso e de práticas adequadas para minimizar as perdas de solo por erosão.

Como sugestão para trabalhos futuros, o levantamento detalhado dos tipos de solos e morfologia das vertentes ofereceria resultados mais precisos, diminuindo as deficiências intrínsecas da equação e ofereceria melhor planejamento em tomadas de decisões relativas ao sistema socioeconômico. 


\section{REFERÊNCIAS}

AMORIM, R. S. S.; SILVA, D. D.; PRUSKI, F. F. Principais modelos para estimar as perdas de solo em áreas agrícolas. In: PRUSKI, F. F. Conservação de solo e água: práticas mecânicas para o controle da erosão hídrica. 2. ed. Viçosa, MG: Ed. UFV, 2009. 279 p.

AMORIM, R. de F. Potencialidade à degradação na Microbacia Riacho Passagem/RN. 2010. $108 \mathrm{f}$. Dissertação (Mestrado em Desenvolvimento e Meio Ambiente). Universidade Federal do Rio Grande do Norte (PRODEMA / UFRN). Natal, RN.

ARAGÃO, R. de et al. Mapeamento do potencial de erosão laminar na Bacia do Rio Japaratuba, SE via SIG. Rev. Brasileira de Engenharia Agrícola e Ambiental. Campina Grande. v. 15, n. 17, p. 731-740, 2011.

ARRAES, C. L. et al. Estimativa da erodibilidade do solo para fins conservacionistas na Microbacia Córrego do Tijuco, SP. Rev. Bioscience Journal. Uberlândia, v. 26, n. 6, p. 849-857, nov./dez. 2010.

ASTARAS, T. Drainage basins as process-response systems an example from Central Macedonia, North Greece. Rev. Earth Surface Process and Landforms. Vol. 9, p. 333-341, 1984.

BELLINAZZI JÚNIOR, R.; BERTOLINI, D.; LOMBARDI NETO, F. A ocorrência de erosão urbana no estado de São Paulo. Anais Simpósio sobre o Controle de Erosão. São Paulo: ABGE, 1981. p. 117-137.

BERTOL, I.; SCHICK, J.; BATISTELA, O. Razão de perdas de solo e fator C para as culturas de soja e trigo em três sistemas de preparo em um Cambissolo Húmico Alumínico. Revista Brasileira de Ciência do Solo, Viçosa, v. 25, p. 451-461, 2001.

BERTONI, J.; LOMBARDI NETO, F. Conservação do solo. 8. ed. São Paulo: Ícone, 2012.

BOIN, M. R. Chuvas e erosões no Oeste Paulista: uma análise climatológica aplicada. 2000281 f. Tese (Doutorado em Geociências). IGCE, Universidade Estadual Paulista. Rio Claro.

BRASIL. Serviço Nacional de Pesquisas Agronômicas. Comissão de Solos. Levantamento de reconhecimento dos solos do Estado de São Paulo. Rio de Janeiro. Ministério da Agricultura, n. 12, 1960. Boletim.

BUENO, C. R. P. Zoneamento da susceptibilidade à erosão dos solos da alta e média bacia do Rio Jacaré - Pepira - SP. Com vistas ao planejamento ambiental. 1994. 137 f. Tese. (Doutorado em Geociências e Meio Ambiente). IGCE, Universidade Estadual Paulista. Rio Claro. 
BUENO, C. R. P. e STEIN, D. P. Potencial natural e antrópico de erosão na região de Brotas, Estado de São Paulo. Rev. Acta Scientiarum. Agronomy Maringá, v. 26, n. 1, p. 1-5, 2004.

CARVALHO, M. de P. Predição de perda de terra por erosão na lavoura canavieira paulista. Disponível em: <http://www.feis.unesp.br/Home/depar tamentos/fitossanidadeengenhariaruralesolos715/erosao-cana.pdf>. UNESP, 2012. Acesso em: 13 out. 2014.

CASSETI, Valter. Geomorfologia. [S.I.]: [2005]. Disponível em: <http://www. funape.org.br/geomorfologia/>. Acesso em: 5 maio 2015.

CAVALIERI, A. Estimativa da adequação de uso das terras na quadrícula de Moji Mirim (SP) utilizando diferentes métodos. 1998. 127f. Tese (Doutorado em Engenharia Agrícola). Faculdade de Engenharia Agrícola da Universidade Estadual de Campinas. Campinas SP.

CETEC. Centro Tecnológico da Fundação Paulista de Tecnologia e Educação. $\mathrm{CBH}-\mathrm{BT}$ Comitê da Bacia Hidrográfica do Baixo Tietê. Plano de Bacia do Baixo Tietê. Relatório Final, 1999.

CHORLEY, R.J. (Ed.). Introduction to physical hydrology. London: Methuen, 1973.

CHRISTOFOLETTI, A. Análise de sistemas em geografia. São Paulo: HUCITEC, 1979.

CHRISTOFOLETTI, A. As perspectivas dos estudos geográficos. In: Perspectivas da geografia. São Paulo: Difel, 1982.

CHRISTOFOLETTI, A. Aspectos da análise sistêmica em geografia. Geografia. Rio Claro/SP, p. 1-31, out. 1978..

CHRISTOFOLETTI, A. Modelagem de sistemas ambientais. São Paulo: Edgard Blücher, 1999.

CHRISTOFOLETTI, A. Geomorfologia. 2. ed. São Paulo: Edgard Blücher, 1980.

COELHO, A. P. Fator erosividade da chuva de Votuporanga (SP). Ilha Solteira, 2001, 101p. Dissertação (Mestrado em Agronomia)- Faculdade de Engenharia de Ilha Solteira, Universidade Estadual Paulista - UNESP.

COLODRO, G. Erosividade da chuva: distribuição e correlação com a precipitação pluviométrica de Teodoro Sampaio (SP). Ilha Solteira, 1999, 77 p. Dissertação (Mestrado em Agronomia)- Faculdade de Engenharia de llha Solteira, Universidade Estadual Paulista - UNESP. 
COLODRO, G. et al. Erosividade da chuva: distribuição e correlação com a precipitação pluviométrica de Teodoro Sampaio (SP). Revista Brasileira de Ciência do Solo, v. 26, p. 809-818, 2002.

CORRÊA. E.A. Caracterização da cobertura vegetal na equação universal de perda de solos (fator C) por meio de geotecnologias. 2011. $167 \mathrm{f}$. Dissertação (Mestrado em Geografia) Universidade Estadual Paulista, Instituto de Geociências e Ciências Exatas. Rio Claro.

COSTA, A. L.C. da. Estudo da vulnerabilidade à erosão com a aplicação da Equação Universal de Perda de Solo na Alta Bacia Hidrográfica do Rio Jacaré Pepira, utilizando SIG/SPRING. 2005. Dissertação (Mestrado em Geociências - Área de Concentração em Geociências e Meio Ambiente). Instituto de Geociências e Ciências Exatas. Universidade Estadual PaulistaUNESP. Campus de Rio Claro.

DEMARCHI, J. C. Geotecnologias aplicadas à estimativa de perdas de solo por erosão hídrica na Sub-Bacia do Ribeirão das Perobas, município de Santa Cruz do Rio Pardo - SP. 2012. 167 f. Dissertação (Mestrado em Agronomia). Faculdade de Ciências Agronômicas da Unesp - Câmpus de Botucatu. Botucatu, SP.

EMBRAPA- Centro Nacional de Pesquisa de Solos. Sistema brasileiro de classificação de solos. 2. ed. Rio de Janeiro, 2006.

EMPLASA, Empresa Paulista de Planejamento Metropolitano S/A. Imagens ortorretificadas, Resolução 1 m. zona 22 e 23. 2010/2011.

ESPÍNDOLA, C. R. Gênese e evolução das formações superficiais nos trópicos. 1. Ed. São Paulo: Editora Beca, 2013.

FEITOSA, M. V. Variação temporal do Índice de vegetação (NDVI) correlacionada ao uso e manejo do solo para a estimativa da erosão. 2006. 143f. Dissertação (Mestrado em Agricultura Tropical e Subtropical) Instituto Agronômico de Campinas. Campinas.

FERNÁNDEZ, B.; SANTOS, J.F. (1980). Determinação do fator de erodibilidade (K) em três solos do estado da Paraíba. Agropecuária Técnica 1, p.183-190.

FERNANDEZ, G. A. V. Análise da erosão do solo usando a EUPS, através de técnicas de sensoriamento remoto e geoprocessamento. 1996. 165p f. Dissertação (Mestrado em sensoriamento remoto). Instituto Nacional de Pesquisas Espaciais. São José dos Campos, SP.

FLORENZANO, T. G. Imagens de satélites para estudos ambientais. São Paulo: Oficina de Textos, 2002. 
FOSTER, G. R. et. al. (1981). Conversion of the Universal Soil Loss Equation to SI metric units. Journal of Soil and Water Conservation. Vol. 36, n. 6, p. 355359.

FREIRE, O.; PESSOTTI, J. E. S. Erodibilidade dos solos do estado de São Paulo. Anais da E.S.A. Luiz de Queiroz. Vol. XXXI, 1974. p. 333-350.

FUJIHARA, A. K. Predição de erosão e capacidade de uso do solo numa microbacia do oeste paulista com suporte de geoprocessamento. 2002. Dissertação. (Mestrado em Ciências. Área de concentração: Ciências Florestais). Universidade de São Paulo. Esalq.

GHIRARDELLO, N. A ocupação da terra rural na zona Noroeste Paulista. In: GHIRARDELLO, N. À beira da linha: formações urbanas da Noroeste Paulista [on-line]. São Paulo: Editora UNESP, 2002. 235 p. Disponível em: <http://bo oks.scielo.org>. Acesso em: 25 jul. 2013.

GUIMARÃES, R. Z. et al. Espacialização da perda de solo por erosão laminar na Microbacia do Rio Campinas, Joinville SC. Rev. RA'E GA, Curitiba, PR, v. 23, p. 534-554, 2011.

IBGE. Instituto Brasileiro de Geografia e Estatística. Manual técnico de uso da terra. Manual Técnico em Geociências n.7. 2. ed. Rio de Janeiro, 2006.

IBGE. Instituto Brasileiro de Geografia e Estatísticas. IBGE Cidades: Fonte IBGE, Produção Agrícola Municipal, 2011. Rio de Janeiro: IBGE, 2012. Disponível em: <www.ibge.gov.br/cidadesat/index.php>. Acesso em: 5 ago. 2013.

INPE. Instituto de Pesquisas Espaciais. Tutorial Spring. Aula 8. Disponível em: <file:///C:/Program\%20Files\%20(x86)/spring433_Port/helpport/indice.htm>. Acesso em: 5 ago. 2013.

JAIN, M. K. ; KOTHYARI, U. C. (2000). Estimation of soil erosion and sediment yield using GIS. Rev. Hydrological Sciences Journal, 45:5, 771-786, DOI: 10.1080/02626660009492376.

JORGE, J. A. Solo: manejo e adubação: compêndio da edafologia. 2. ed. São Paulo: Nobel, 1983.

JORGE, J. A. Física e manejo dos solos tropicais. Instituto Campineiro de Ensino Agrícola, Campinas, 1985.

KELLER, E. A.; MELHORN, W. N. Bed forms and fluvial process in alluvial stream channels: selected observations. In: MORISAWA, M. (Ed.). Fluvial geomorphology. London: Allen \& Unwin, 1981. p. 285-299.

KURATANI, M. C. B. Erosividade da chuva de Mirandópolis (SP): distribuição, período de retorno e probabilidade de ocorrência. 2001. $56 \mathrm{f}$. 
Monografia (Aperfeiçoamento/Especialização em Geografia) - Universidade Federal de Mato Grosso do Sul.

LAGROTTI, C. A. A. Planejamento agroambiental do município de Santo Antônio do Jardim - SP: Estudo de caso na Microbacia Hidrográfica do Córrego do Jardim. 2000. 133 f. Tese (Doutorado em Engenharia Agrícola). Faculdade de Engenharia Agrícola - FEAGRI, Campinas.

LEPSCH, I. F. Solos do Estado de São Paulo. In: LOMBARDI NETO, F. ; DRUGOWICH, M. I. (Coord.). Manual técnico de manejo e conservação do solo e água. CATI. n. 39. Campinas, p. 70-121, 1994.

LEPSCH, I. F. 19 lições de pedologia. São Paulo: Oficina de Textos, 2011.

LIMA, E. R. V. de. Erosão do solo: fatores condicionantes e modelagem matemática. Revista Cadernos do Logepa - Série Pesquisa. v. 1, n. 1, p. 343, jan./jun. 2003.

LIMA, J. E. F. W. et al. Desenvolvimento e verificação de métodos indiretos para a estimativa da erodibilidade dos solos da bacia experimental do Alto Rio Jardim-DF. Revista Brasileira de Geomorfologia, v. 8, n. 2, p. 21-34, 2007.

LOMBARDI NETO, F.; MOLDENHAUER, W. C. Erosividade da chuva: sua distribuição e relação com perdas de solo em Campinas, SP. Bragantia, v. 51, p. 189-196, 1992.

LUCHIARI, A. Procedimentos de tratamento da informação geográfica: aplicação de técnicas de geoprocessamento como subsídio à análise de processos denudacionais. 1994. 204 f. Tese (Doutorado em Geografia Física) Universidade de São Paulo. São Paulo, SP.

MACHADO, R. E.; VETORAZZI, C. A. ; XAVIER, A. C. Simulação de cenários alternativos de uso da terra em uma microbacia utilizando técnicas de modelagem e geoprocessamento. Revista Brasileira de Ciência do Solo [online]. vol. 27, n. 4, p. 727-733, 2003.

MANNIGEL, A. R. et al. Fator erodibilidade e tolerância de perda dos solos do Estado de São Paulo. Rev. Acta Scientiarum. Maringá, v. 24, n. 5, p. 13351340, 2002.

MARDEGAN, C. M. A ocorrência de espécies de cerrado em 18 fragmentos com fisionomia florestal no noroeste do estado de São Paulo e as características do solo. 91f. 2012. Tese (Doutorado em Ciências Biológicas). Universidade Estadual Paulista. Botucatu, SP.

MARTINS, S. G. Erosão hídrica em povoamento de eucalipto sobre solos coesos nos tabuleiros costeiros, ES. 2005. 117f. Tese (Doutorado em Agronomia) Universidade Federal de Lavras. Minas Gerais. 
MENDES, I. A. A dinâmica erosiva do escoamento pluvial na Bacia do Córrego Lafon, Araçatuba, SP. 1993. 171 f. Tese (Doutorado em Geografia Física) Faculdade de Filosofia, Letras e Ciências Humanas. Universidade de São Paulo. São Paulo.

MIGUEL, P. Caracterização pedológica, uso da terra e modelagem da perda de solo em áreas de encosta do rebordo do Planalto do RS. 2010. 112f. Dissertação (Mestrado em Ciência do Solo) Universidade Federal de Santa Maria. Santa Maria, RS.

MILANI E.J. et al. Bacia do Paraná. Boletim Geociências Petrobras. v. 15, n. 2, p. 265-287, maio/nov. 2007.

MINELLA, J. P.G. et al. Utilização de métodos de representação espacial para Cálculo do Fator Topográfico na Equação Universal de Perda de Solo revisada em bacias hidrográficas. Revista Brasileira de Ciência do Solo, n. 34, p. 1455-1462, 2010.

MINOTI, R. T. Abordagens qualitativa e quantitativa de micro-bacias hidrográficas e áreas alagáveis de um compartimento do Médio MogiSuperior/SP. 231 f. (Tese em Ciências da Engenharia Ambiental). São Carlos, 2006.

MITASOVA, $\mathrm{H}$. et al. (1996) Modelling topographic potential for erosion and deposition using GIS. International Journal of Geographical Information Systems, vol. 10, n. 5, p. 629-641.

MITASOVA, $H$. et al. GIS tools for erosion/deposition modeling and multidimensional visualization. Part V: Impact of transport capacity and terrain structures on erosion simulations. 1997. Geographic Modeling and Systems Laboratory, University of Illinois at Urbana-Champaign, Urbana, Illinois. Disponível em: <http://www4.ncsu.edu/ hmitaso/gmslab/reports/ cerl97/rep97.html>. Acesso em: 6 maio 2015.

MITCHELL, J. K.; BUBENZER, G. D. Soil loss estimation. In: KIRKBY, M. J.; MORGAN, R. P. C. Soil erosion. Nova York: Jon Wiley and Sons Ltd., 1980. p. 17-62.

MONTEIRO, C. A. de F. A dinâmica climática e as chuvas no Estado de São Paulo. IGEOG/USP, São Paulo, 1973.

MORETI, D. et al. Importantes características de chuva para a conservação do solo e da água no município de São Manuel (SP). Rev. Brasileira de Ciência do Solo, Viçosa, n. 27, p. 713-725, 2003.

MORETI, D. et al. Fator erosividade da chuva para o município de Pedrinhas Paulista, Estado de São Paulo. Acta Scientiarum: Agronomy. Maringá, v. 25, n. 1, p. 137-145, 2003. 
MORISAWA, M. Rivers, form and process.. New York: Longman Group, 1985.

OLIVEIRA, V. H.; BAHIA, V.G. Erodibilidade de seis solos do município de Lavras - MG, usando o nomograma. Pesquisa Agropecuária Brasileira. Brasília. v. 19, n. 9, p. 1157-1162, 1984.

OLIVEIRA, J. B. Solos do Estado de São Paulo: descrição das classes registradas no mapa pedológico. Campinas, Instituto Agronômico, 1999. 108p.

OLIVEIRA, A. C. M. Aplicação de geotecnologias e do modelo EUPS como subsídio ao planejamento do uso da terra: estudo de caso no alto curso da microbacia hidrográfica do Ribeirão Cachoeirinha, Iracemápolis, S.P. 2004. 119 f. Tese (Doutorado em Geografia) Universidade Estadual Paulista, Rio Claro.

PEREZ FILHO, A. Análise estrutural da Bacia do São José dos Dourados (SP). 1977. 122 f. Dissertação (Mestrado em geomorfologia) - Faculdade de Filosofia Ciências e Letras Humanas, Universidade de São Paulo, São Paulo.

PINTO, S. A. F. Sensoriamento remoto e integração de dados aplicados no estudo da erosão dos solos: contribuição metodológica. 1991. Tese (Doutorado em Geografia Física). Universidade de São Paulo, São Paulo.

PINTO, S. dos A. F.; GARCIA, G. J. Experiências de aplicação de geotecnologias e modelos na análise de bacias hidrográficas. Rev. do Departamento de Geografia, São Paulo. n. 17, p. 30-37, 2005.

PONÇANO, W.; CHRISTOFOLETTI, A. Procedimentos estimativos para taxas de erosão pluvial em regiões tropicais. Marília, SP. Anais. 40 Simpósio Nacional de Controle de Erosão. 1987, p. 263-286.

PRIMAVESI, A. Manejo ecológico do solo e agricultura em regiões tropicais. 9. ed. 3. reimpressão. São Paulo: Nobel, 1990.

PRUSKI, F. F. Conservação do solo e água: práticas mecânicas para 0 controle da erosão hídrica. 2. ed. Viçosa, MG: Ed. UFV, 2009. 279 p.

RENARD, K. G. et al. Predicting soil erosion by water: a guide to conservation planning with the Revised Universal Soil Loss Equation (RUSLE). U.S. Department of Agriculture, Agriculture Handbook N. 703, 404 p.

RENNÓ, C. D. Construção de um sistema de análise e simulação hidrológica: aplicação a aacias hidrográficas. 2003. 148 f. Tese (Doutorado em Sensoriamento Remoto). Instituto Nacional de Pesquisas Espaciais, São José dos Campos, SP.

RESENDE M. et al. Pedologia: base para diminuição de ambientes. 3. ed. Viçosa, MG: NEPU, 1999. 
ROCHA, P. C. O meio físico como ferramenta para o entendimento funcional dos ecossistemas fluviais. III Workshop Internacional sobre Planejamento e Desenvolvimento Sustentável em Bacias Hidrográficas, Fortaleza. Anais do III Workshop Int. Plan. Des. Sust. Bacias Hidrográficas. Fortaleza, 2011.

RODRIGUES, C.; GOUVEIA, I. C. Moroz-Caccia. Importância do fator antrópico na redefinição de processos geomorfológicos e riscos associados em áreas urbanizadas do meio tropical úmido. Exemplos na Grande São Paulo. In: GUERRA, A. J. T.; JORGE, M. do C. O. (Org.). Processos erosivos e recuperação de áreas degradadas. São Paulo: Oficina de Textos, 2013. p. 66-94.

ROO, A. P. J. de; HAZELHOFF, L.; BURROUGH, P. A. (1989). Soil erosion modelling using 'ANSWERS' and Geographical information systems. In: Earth Surface Processes and Landforms, n. 14, p. 517-532.

ROSA, R. Erosão laminar pPotencial em microbacias hidrográficas. Anais VII Simpósio Nacional de Controle de Erosão. Goiânia (GO), 3 a 6 de maio de 2001, p. 1-9.

ROSA, R. A utilização de imagens TM/Landsat em levantamentos de uso do solo. Anais do VI Simpósio Brasileiro de Sensoriamento Remoto, Manaus. 1990. v. 2. p. $419-425$.

ROSS, J. L. S. Ecogeografia do Brasil: subsídios para planejamento ambiental. São Paulo: Oficina de Textos, 2006. 208 p.

ROQUE, C. G.; CARVALHO, M. P.; PRADO, R. M. Fator erosividade da chuva de Piraju (SP): distribuição, probabilidade de ocorrência, período de retorno e correlação com o coeficiente de chuva. RBCiS, v. 25, p. 147-154, 2001.

RUTHES, J. M. et al. Uso de sistema de informação geográfica na determinação do fator topográfico da Bacia do Rio Catorze, Sudoeste do PR. Revista Brasileira de Geografia Física. Pernambuco. 05 (2012) 1099-1109.

SALOMÃO, F. X. T. Solos do arenito Bauru. In: PEREIRA, V de P.; FERREIRA, $M, E$. F.; CRUZ, M. C. P. da. Solos altamente suscetíveis à erosão. Jaboticabal, SP: FCAV- UNESP/SBCS, 1994. 253 p, p. 51-66.

SANTOS, J. A. A. Fator erosividade da chuva para o município de MaringáPR: distribuição, probabilidade de ocorrência, período de retorno e correlação com o coeficiente de chuva. 2006. 61 f.. Dissertação (Mestrado em Agronomia, na área concentração Solos e Nutrição de Plantas). Universidade Estadual de Maringá. UEM. Maringá-PR.

SILVA, M. L. N.; CURI, N.; LIMA, J. M. de; FERREIRA, M. M. Avaliação de métodos indiretos de determinação da erodibilidade de latossolos brasileiros. Revista Pesquisa Agropecuária brasileira, Brasília, v. 35, n. 6, p. 1207-1220, jun. 2000. 
SOUZA, C. K. et al. Influência do relevo e erosão na variabilidade espacial de um latossolo em Jaboticabal (SP). Rev. Brasileira de Ciência do Solo. vol. 27, p. 1067-1074, 2003.

SOUZA, W. de. Estimativa de perdas de solo por erosão laminar na bacia do Córrego Pinhalzinho II com suporte de geoprocessamento. 2010 . $75 \mathrm{f}$. Dissertação (Mestrado em Geografia). Universidade Estadual de Maringá UEM. Maringá, PR.

STEIN, D. P. et al. Potencial de erosão laminar, natural e antrópico, na Bacia do Peixe-Paranapanema. Anais Simpósio Nacional de Controle de Erosão, 4․ Marília, SP. Fev. 1987, p. 105-135.

STEIN, D. P.; PONÇANO, W. L.; SAAD, A. R. Erosão na Bacia do Rio Santo Anastácio, oeste do estado de São Paulo, Brasil. Rev. Geociências, v. 22, n. 2, São Paulo, UNESP, p. 143-162, 2003.

SUDO, H. A problemática da erosão em solos derivados do arenito Bauru na região extremo oeste do estado de São Paulo. Anais Simpósio sobre controle de erosão, São Paulo, v. 2,p. 185-194, 1981.

SUGUIMOTO, E. I. A expansão da cana em Birigui e a dinâmica agrária regional. 2011. 135 f. Dissertação (Mestrado em Geografia). Universidade Federal do Mato Grosso do Sul. Três Lagoas, MS.

TAVARES. A. C. A erosão dos solos no contexto da análise ambiental: o exemplo do alto curso do Rio São José dos Dourados. 1986. 254 f. Tese (Doutorado em Geografia). Faculdade de Filosofia, Letras e Ciências Humanas. Universidade de São Paulo. São Paulo.

TOMAZONI, J. C.; GUIMARÃES, E. A sistematização dos fatores da EUPS em SIG para quantificação da erosão laminar na Bacia do Rio Jirau. RBC - Revista Brasileira de Cartografia. № 57/03, p. 1-10 e p. 236, 2005.

VALENTIM, E. F. D. Modelagem dinâmica de perda de solo: o caso do alto Ccrso da Bacia Hidrográfica do Rio Descoberto - DF/GO. 2008. 113f. Tese (Doutorado em Geologia). Universidade de Brasília, Instituto de Geociências. Brasília DF.

VASQUEZ-FERNÁNDEZ, G. A. et al. Determinação de sequências culturais em microbacia hidrográfica para caracterização do Fator $C$ da EUPS, utilizando fotografia aérea. Anais VIII Simpósio Brasileiro de Sensoriamento Remoto, Salvador, Brasil, 14-19 abril 1996, INPE, p. 63-67.

VALERIANO, $M$. de $M$. Mapeamento do comprimento de rampa em microbacias com sistema de informação geográfica. Revista Acta Acta Scientiarum. Maringá, v. 24, n. 5, p. 1541-1551, 2002.

VILLELA, S. M.; MATTOS, A. Hidrologia aplicada. São Paulo: McGraw- Hill do Brasil, 1975. 245 p. 
WILSON, J. P. Estimating the topographic factor in the universal soil loss equation for watersheds. Rev. Journal of Soil and Water Conservation, $p$. 179-1984, maio-jun. 1986.

WISCHMEIER, W. H.; SMITH, D. D. Predicting rainfall erosion losses - a guide to conservation planning. Washington, D.C.: USDA, 1978. 58 p. (Agriculture Handbook, 537).

YANG, C. T.; STALL, J. B. Unit stream power in dynamic stream systems. In: MORISAWA, M. (Ed.). Fluvial geomorphology. London: Allen \& Unwin, 1981. 304 p. p. 285 a 299. 
APÊNDICE 
APÊNDICE A - Distribuição mensal e anual da precipitação pluviométrica de Araçatuba/SP entre 1971 e 2000

\section{Precipitação pluviométrica $(\mathrm{mm})$}

\begin{tabular}{|c|c|c|c|c|c|c|c|c|c|c|c|c|c|c|c|c|c|c|c|c|c|c|c|c|c|c|c|c|c|c|c|}
\hline Mês & 1971 & 1972 & 1973 & 1974 & 1975 & 1976 & 1977 & 1978 & 1979 & 1980 & 1981 & 1982 & 1983 & 1984 & 1985 & 1986 & 1987 & 1988 & 1989 & 1990 & 1991 & 1992 & 1993 & 1994 & 1995 & 1996 & 1997 & 1998 & 1999 & 2000 & Média \\
\hline JAN & 192,5 & 175,0 & 179,7 & 304,9 & 175,0 & 283,3 & 260,5 & 141,1 & 57,8 & 130,6 & 190,5 & 207,1 & 348,1 & 201,4 & 205,5 & 164,9 & 234,8 & 156,1 & 320,8 & 225,0 & 349,7 & 80,9 & 203,3 & 268,4 & 178,6 & 94,7 & 251,1 & 140,5 & 386,6 & 60,1 & 205,6 \\
\hline FEV & 48,7 & 249,1 & 179,9 & 81,8 & 128,4 & 293,9 & 58,9 & 89,0 & 155,4 & 413,4 & 275,1 & 127,5 & 215,3 & 90,7 & 367,7 & 202,6 & 332,5 & 214,7 & 299,6 & 67,1 & 148,1 & 94,7 & 216,1 & 152,6 & 254,7 & 59,5 & 105,8 & 173,9 & 183,3 & 252,8 & 184,4 \\
\hline MAR & 178,0 & 102,6 & 57,9 & 252,1 & 43,1 & 136,0 & 154,8 & 165,1 & 87,1 & 42,6 & 39,9 & 337,8 & 108,3 & 150,3 & 348,8 & 125,3 & 65,1 & 162,3 & 145,8 & 113,1 & 325,6 & 154,8 & 173,9 & 141,1 & 70,5 & 272,1 & 61,8 & 266,1 & 91,9 & 144,5 & 150,6 \\
\hline ABR & 35,0 & 71,1 & 152,5 & 13,8 & 113,5 & 54,4 & 45,9 & 13,8 & 95,9 & 88,5 & 89,4 & 38,2 & 107,4 & 73,4 & 88,4 & 44,8 & 71,5 & 95,2 & 17,4 & 110,6 & 60,1 & 115,8 & 65,0 & 122,0 & 68,8 & 39,6 & 98,5 & 134,4 & 66,2 & 2,0 & 73,1 \\
\hline MAI & 164,8 & 63,2 & 83,0 & 74,5 & 10,8 & 158,2 & 11,1 & 97,7 & 116,0 & 37,3 & 0,0 & 94,5 & 65,5 & 33,3 & 42,5 & 177,6 & 80,9 & 149,7 & 45,0 & 44,5 & 2,6 & 123,9 & 34,6 & 23,6 & 36,0 & 57,7 & 64,1 & 31,8 & 57,8 & 5,2 & 66,2 \\
\hline JUN & 123,1 & 0,8 & 19,4 & 78,6 & 7,5 & 24,2 & 79,4 & 7,2 & 0,0 & 63,4 & 67,9 & 54,9 & 14,2 & 0,0 & 14,5 & 0,0 & 3,6 & 6,1 & 80,7 & 20,3 & 47,6 & 3,3 & 53,9 & 10,2 & 37,7 & 14,7 & 177,5 & 3,0 & 39,5 & 0,0 & 35,1 \\
\hline JUL & 96,1 & 125,7 & 22,7 & 0,0 & 25,7 & 26,4 & 0,7 & 93,8 & 27,5 & 0,0 & 0,0 & 52,2 & 11,8 & 0,0 & 18,9 & 66,0 & 25,5 & 0,0 & 23,5 & 11,6 & 21,1 & 11,8 & 0,0 & 9,7 & 21,2 & 0,7 & 12,0 & 0,0 & 0,0 & 23,0 & 24,3 \\
\hline AGO & 0,0 & 73,2 & 19,3 & 9,9 & 0,0 & 92,7 & 8,4 & 0,0 & 32,1 & 66,9 & 5,6 & 20,2 & 0,0 & 27,1 & 1,4 & 84,3 & 0,0 & 0,0 & 70,8 & 112,6 & 0,0 & 21,0 & 46,2 & 0,0 & 0,0 & 32,4 & 2,0 & 88,1 & 0,0 & 25,2 & 28,0 \\
\hline SET & 98,4 & 84,3 & 43,5 & 21,2 & 10,3 & 126,9 & 29,0 & 100,5 & 129,3 & 99,7 & 15,3 & 10,1 & 182,4 & 53,6 & 24,2 & 2,4 & 61,7 & 3,6 & 61,7 & 120,4 & 13,9 & 189,4 & 70,4 & 1,5 & 33,5 & 101,8 & 53,5 & 152,5 & 52,8 & 27,1 & 65,8 \\
\hline OUT & 20,8 & 184,1 & 90,7 & 117,5 & 116,4 & 190,0 & 59,1 & 128,0 & 43,8 & 60,3 & 129,1 & 135,0 & 169,3 & 39,0 & 41,4 & 96,3 & 124,8 & 183,1 & 96,3 & 77,0 & 96,3 & 77,3 & 24,7 & 148,1 & 91,4 & 140,9 & 166,0 & 198,3 & 27,2 & 10,2 & 102,7 \\
\hline NOV & 72,3 & 263,7 & 104,4 & 119,2 & 235,3 & 92,9 & 184,3 & 71,8 & 109,9 & 99,7 & 157,7 & 103,1 & 106,1 & 59,2 & 144,0 & 106,1 & 243,4 & 43,5 & 106,1 & 159,1 & 48,9 & 154,8 & 65,9 & 154,0 & 46,2 & 116,7 & 144,0 & 129,6 & 113,2 & 61,6 & 120,6 \\
\hline DEZ & 241,4 & 132,8 & 201,7 & 252,6 & 224,8 & 235,0 & 390,2 & 178,9 & 223,9 & 160,3 & 201,7 & 272,4 & 170,3 & 190,0 & 68,6 & 242,2 & 86,2 & 355,5 & 288,4 & 115,0 & 176,9 & 34,0 & 177,0 & 132,2 & 162,0 & 128,2 & 46,1 & 170,3 & 118,0 & 71,5 & 181,6 \\
\hline
\end{tabular}


APÊNDICE B - Distribuição mensal e anual dos índices de erosividade de Araçatuba/SP entre 1971 e 2000.

\section{Erosividade $\mathrm{ei}_{30}$ (MJ.mm/ha.h.ano)}

\begin{tabular}{|c|c|c|c|c|c|c|c|c|c|c|c|c|c|c|c|c|c|c|c|c|c|c|c|c|c|c|c|c|c|c|c|}
\hline Mês & 1971 & 1972 & 1973 & 1974 & 1975 & 1976 & 1977 & 1978 & 1979 & 1980 & 1981 & 1982 & 1983 & 1984 & 1985 & 1986 & 1987 & 1988 & 1989 & 1990 & 1991 & 1992 & 1993 & 1994 & 1995 & 1996 & 1997 & 1998 & 1999 & 2000 & Média \\
\hline JAN & 1190 & 1081 & 1110 & 1884 & 1081 & 1751 & 1610 & 872 & 357 & 807 & 1177 & 1280 & 2151 & 1245 & 1270 & 1019 & 1451 & 965 & 1982 & 1390 & 2161 & 500 & 1256 & 1659 & 1104 & 585 & 1552 & 868 & 2389 & 371 & 1271 \\
\hline FEV & 316 & 1615 & 1167 & 530 & 833 & 1906 & 382 & 577 & 1008 & 2681 & 1784 & 827 & 1396 & 588 & 2384 & 1314 & 2156 & 1392 & 1943 & 435 & 960 & 614 & 1401 & 990 & 1652 & 386 & 686 & 1128 & 1189 & 1639 & 1196 \\
\hline MAR & 1142 & 658 & 371 & 1617 & 276 & 872 & 993 & 1059 & 559 & 273 & 256 & 2167 & 695 & 964 & 2237 & 804 & 418 & 1041 & 935 & 725 & 2089 & 993 & 1115 & 905 & 452 & 1745 & 396 & 1707 & 589 & 927 & 966 \\
\hline ABR & 157 & 320 & 686 & 62 & 511 & 245 & 207 & 62 & 432 & 398 & 402 & 172 & 483 & 330 & 398 & 202 & 322 & 428 & 78 & 498 & 270 & 521 & 292 & 549 & 310 & 178 & 443 & 605 & 298 & 9 & 329 \\
\hline MAI & 706 & 271 & 356 & 319 & 46 & 678 & 48 & 419 & 497 & 160 & 0 & 405 & 281 & 143 & 182 & 761 & 347 & 641 & 193 & 191 & 11 & 531 & 148 & 101 & 154 & 247 & 275 & 136 & 248 & 22 & 284 \\
\hline JUN & 446 & 3 & 70 & 285 & 27 & 88 & 288 & 26 & 0 & 230 & 246 & 199 & 51 & 0 & 53 & 0 & 13 & 22 & 292 & 74 & 172 & 12 & 195 & 37 & 137 & 53 & 643 & 11 & 143 & 0 & 127 \\
\hline JUL & 372 & 486 & 88 & 0 & 99 & 102 & 3 & 363 & 106 & 0 & 0 & 202 & 46 & 0 & 73 & 255 & 99 & 0 & 91 & 45 & 82 & 46 & 0 & 38 & 82 & 3 & 46 & 0 & 0 & 89 & 94 \\
\hline AGO & 0 & 272 & 72 & 37 & 0 & 344 & 31 & 0 & 119 & 249 & 21 & 75 & 0 & 101 & 5 & 313 & 0 & 0 & 263 & 418 & 0 & 78 & 172 & 0 & 0 & 120 & 7 & 327 & 0 & 94 & 104 \\
\hline SET & 420 & 360 & 186 & 91 & 44 & 542 & 124 & 429 & 552 & 426 & 65 & 43 & 779 & 229 & 103 & 10 & 264 & 15 & 264 & 514 & 59 & 809 & 301 & 6 & 143 & 435 & 228 & 651 & 226 & 116 & 281 \\
\hline OUT & 113 & 998 & 492 & 637 & 631 & 1030 & 320 & 694 & 237 & 327 & 700 & 732 & 917 & 211 & 224 & 522 & 676 & 992 & 522 & 417 & 522 & 419 & 134 & 803 & 495 & 764 & 900 & 1075 & 147 & 55 & 557 \\
\hline NOV & 426 & 1552 & 615 & 702 & 1385 & 547 & 1085 & 423 & 647 & 587 & 928 & 607 & 624 & 348 & 848 & 624 & 1433 & 256 & 624 & 936 & 288 & 911 & 388 & 906 & 272 & 687 & 848 & 763 & 666 & 363 & 710 \\
\hline DEZ & 1570 & 864 & 1312 & 1643 & 1462 & 1528 & 2538 & 1163 & 1456 & 1043 & 1312 & 1772 & 1107 & 1236 & 446 & 1575 & 561 & 2312 & 1876 & 748 & 1150 & 221 & 1151 & 860 & 1054 & 834 & 300 & 1107 & 767 & 465 & 1181 \\
\hline $\begin{array}{l}\text { TOTA } \\
\text { L } \\
\text { anual }\end{array}$ & 6857 & 8480 & 6523 & 7806,1 & 6396 & 9632 & 7627 & 6087 & 5970 & 7179 & 6891 & 8479 & 8531 & 5395 & 8224 & 7399 & 7738 & 8065 & 9063 & 6392 & 7765 & 5654 & 6554 & 6853 & 5854 & 6037 & 6324 & 8378 & 6662 & 4150 & 7099 \\
\hline
\end{tabular}


APÊNDICE C - ei30 médio, absoluto, absoluto acumulado e relativo acumulado

\begin{tabular}{c|c|c|c|c}
\hline Mês & $\begin{array}{c}\text { ei30 } \\
\text { médio }\end{array}$ & $\begin{array}{c}\text { ei30 } \\
\text { absoluto }\end{array}$ & $\begin{array}{c}\text { ei30 } \\
\text { absoluto } \\
\text { acumulado }\end{array}$ & $\begin{array}{c}\text { ei30 } \\
\text { relativo } \\
\text { acumulado }\end{array}$ \\
\hline & & & & $(\%)$ \\
\hline Jul & 94 & 0,01 & 0,0132 & 1,32 \\
\hline Ago & 104 & 0,01 & 0,0279 & 2,79 \\
\hline Set & 281 & 0,04 & 0,0675 & 6,75 \\
\hline Out & 557 & 0,08 & 0,1459 & 14,59 \\
\hline Nov & 710 & 0,10 & 0,2459 & 24,59 \\
\hline Dez & 1181 & 0,17 & 0,4122 & 41,22 \\
\hline Jan & 1271 & 0,18 & 0,5912 & 59,12 \\
\hline Fev & 1196 & 0,17 & 0,7597 & 75,97 \\
\hline Mar & 966 & 0,14 & 0,8957 & 89,57 \\
\hline Abr & 329 & 0,05 & 0,9421 & 94,21 \\
\hline Mai & 284 & 0,04 & 0,9821 & 98,21 \\
\hline Jun & 127 & 0,02 & 1,0000 & 100,00 \\
\hline TOTAL & 7099 & 1,0000 & - & - \\
\hline
\end{tabular}

APÊNDICE D - Cana planta de ano em preparação convencional

\begin{tabular}{|c|c|c|c|c|c|c|c|c|}
\hline Data & R acum \% & Estágio & $\begin{array}{l}\text { R estag. } \\
\text { Relativo }\end{array}$ & $\begin{array}{l}\text { RPS } \\
\text { estag. }\end{array}$ & Fator c & $\begin{array}{c}\text { FATOR C } \\
\text { ANUAL }\end{array}$ & ANO & $\begin{array}{r}\text { FATOR } \\
\text { C CICLO } \\
\end{array}$ \\
\hline Prim. Set & 2,79 & $\$$ & $\$$ & $\$$ & $\$$ & $\$$ & & 0,0149 \\
\hline Prim. Out & 6,75 & $\mathrm{D}(1)$ & 0,03960 & 0,2000 & 0,0079 & & & \\
\hline Prim. Nov & 14,59 & $1(1)$ & 0,07840 & 0,1600 & 0,0125 & & & \\
\hline Prim. Dez & 24,59 & $2(1)$ & 0,10000 & 0,0800 & 0,0080 & & & \\
\hline Prim. Ago & 101,32 & $3(8)$ & 0,76730 & 0,0200 & 0,0153 & & & \\
\hline Prim. Set & 102,79 & $4(1)$ & 0,01470 & 0,0600 & 0,0009 & 0,0447 & $\mathrm{CP}$ & \\
\hline Prim. Out & 106,75 & $D(1)$ & 0,03960 & 0,0400 & 0,0016 & & & \\
\hline Prim. Nov & 114,59 & $1(1)$ & 0,07840 & 0,0320 & 0,0025 & & & \\
\hline Prim. Dez & 124,59 & $2(1)$ & 0,10000 & 0,0160 & 0,0016 & & & \\
\hline
\end{tabular}




\begin{tabular}{|c|c|c|c|c|c|c|c|}
\hline Prim. Ago & 201,32 & $3(8)$ & 0,76730 & 0,0040 & 0,0031 & & \\
\hline Prim. Set & 202,79 & $4(1)$ & 0,01470 & 0,0120 & 0,0002 & 0,0089 & $1 \mathrm{~s}$ \\
\hline Prim. Out & 206,75 & $\mathrm{D}(1)$ & 0,03960 & 0,0400 & 0,0016 & & \\
\hline Prim. Nov & 214,59 & $1(1)$ & 0,07840 & 0,0320 & 0,0025 & & \\
\hline Prim. Dez & 224,59 & $2(1)$ & 0,10000 & 0,0160 & 0,0016 & & \\
\hline Prim. Ago & 301,32 & $3(8)$ & 0,76730 & 0,0040 & 0,0031 & & \\
\hline Prim. Set & 302,79 & $4(1)$ & 0,01470 & 0,0120 & 0,0002 & 0,0089 & $2 S$ \\
\hline Prim. Out & 306,75 & $D(1)$ & 0,03960 & 0,0400 & 0,0016 & & \\
\hline Prim. Nov & 314,59 & $1(1)$ & 0,07840 & 0,0320 & 0,0025 & & \\
\hline Prim. Dez & 324,59 & $2(1)$ & 0,10000 & 0,0160 & 0,0016 & & \\
\hline Prim. Ago & 401,32 & $3(8)$ & 0,76730 & 0,0040 & 0,0031 & & \\
\hline Prim. Set & 402,79 & $4(1)$ & 0,01470 & 0,0120 & 0,0002 & 0,0089 & $3 S$ \\
\hline Prim. Out & 406,75 & $\mathrm{D}(1)$ & 0,03960 & 0,0400 & 0,0016 & & \\
\hline Prim. Nov & 414,59 & $1(1)$ & 0,07840 & 0,0320 & 0,0025 & & \\
\hline Prim. Dez & 424,59 & $2(1)$ & 0,10000 & 0,0160 & 0,0016 & & \\
\hline Prim. Ago & 501,32 & $3(8)$ & 0,76730 & 0,0040 & 0,0031 & & \\
\hline Prim. Set & 502,79 & $4(1)$ & 0,01470 & 0,0120 & 0,0002 & 0,0089 & $4 S$ \\
\hline Prim. Out & 506,75 & $D(1)$ & 0,03960 & 0,0400 & 0,0016 & & \\
\hline Prim. Nov & 514,59 & $1(1)$ & 0,07840 & 0,0320 & 0,0025 & & \\
\hline Prim. Dez & 524,59 & $2(1)$ & 0,10000 & 0,0160 & 0,0016 & & \\
\hline Prim. Ago & 601,32 & $3(8)$ & 0,76730 & 0,0040 & 0,0031 & & \\
\hline Prim. Set & 602,79 & $4(1)$ & 0,01470 & 0,0120 & 0,0002 & 0,0089 & $5 S$ \\
\hline
\end{tabular}

APÊNDICE E - Cana planta de ano e meio em preparação convencional

\begin{tabular}{c|c|c|c|c|c|c|c}
\hline Data & R acum $\%$ & Estágio & $\begin{array}{c}\text { R estag. } \\
\text { Relativo }\end{array}$ & $\begin{array}{c}\text { RPS } \\
\text { estag. }\end{array}$ & Fator C & $\begin{array}{c}\text { FATOR C } \\
\text { ANUAL }\end{array}$ & FATOR C CICLO \\
\hline Prim. Mar & 75,97 & $\$$ & $\$$ & $\$$ & $\$$ & & 0,0186 \\
\hline Prim. Abr & 89,57 & $\mathrm{D}(1)$ & 0,1360 & 0,2000 & 0,0272 & & \\
\cline { 1 - 6 } Prim. Mai & 94,21 & $1(1)$ & 0,0464 & 0,1600 & 0,0074 & & \\
\cline { 1 - 5 } Prim. Jun & 98,21 & $2(1)$ & 0,0400 & 0,0800 & 0,0032 & & \\
\cline { 1 - 5 } Prim. Jul & 201,00 & $3(13)$ & 1,0279 & 0,0200 & 0,0206 & & \\
\hline
\end{tabular}




\begin{tabular}{|c|c|c|c|c|c|c|}
\hline Prim. Mar & 275,97 & $4(8)$ & 0,7497 & 0,0600 & 0,0450 & 0,0517 \\
\hline Prim. Abr & 289,57 & $\mathrm{D}(1)$ & 0,1360 & 0,0400 & 0,0054 & \\
\hline Prim. Mai & 294,21 & $1(1)$ & 0,0464 & 0,0320 & 0,0015 & \\
\hline Prim. Jun & 298,21 & $2(1)$ & 0,0400 & 0,0160 & 0,0006 & \\
\hline Prim. Fev & 359,12 & $3(8)$ & 0,6091 & 0,0040 & 0,0024 & \\
\hline Prim. Mar & 375,97 & $4(1)$ & 0,1685 & 0,0120 & 0,0020 & 0,0120 \\
\hline Prim. Abr & 389,57 & $\mathrm{D}(1)$ & 0,1360 & 0,0400 & 0,0054 & \\
\hline Prim. Mai & 394,21 & $1(1)$ & 0,0464 & 0,0320 & 0,0015 & \\
\hline Prim. Jun & 398,21 & $2(1)$ & 0,0400 & 0,0160 & 0,0006 & \\
\hline Prim. Fev & 459,12 & $3(8)$ & 0,6091 & 0,0040 & 0,0024 & \\
\hline Prim. Mar & 475,97 & $4(1)$ & 0,1685 & 0,0120 & 0,0020 & 0,0120 \\
\hline Prim. Abr & 489,57 & $D(1)$ & 0,1360 & 0,0400 & 0,0054 & \\
\hline Prim. Mai & 494,21 & $1(1)$ & 0,0464 & 0,0320 & 0,0015 & \\
\hline Prim. Jun & 498,21 & $2(1)$ & 0,0400 & 0,0160 & 0,0006 & \\
\hline Prim. Fev & 559,12 & $3(8)$ & 0,6091 & 0,0040 & 0,0024 & \\
\hline Prim. Mar & 575,97 & $4(1)$ & 0,1685 & 0,0120 & 0,0020 & 0,0120 \\
\hline Prim. Abr & 589,57 & $\mathrm{D}(1)$ & 0,1360 & 0,0400 & 0,0054 & \\
\hline Prim. Mai & 594,21 & $1(1)$ & 0,0464 & 0,0320 & 0,0015 & \\
\hline Prim. Jun & 598,21 & $2(1)$ & 0,0400 & 0,0160 & 0,0006 & \\
\hline Prim. Fev & 659,12 & $3(8)$ & 0,6091 & 0,0040 & 0,0024 & \\
\hline Prim. Mar & 675,97 & $4(1)$ & 0,1685 & 0,0120 & 0,0020 & 0,0120 \\
\hline Prim. Abr & 689,57 & $D(1)$ & 0,1360 & 0,0400 & 0,0054 & \\
\hline Prim. Mai & 694,21 & $1(1)$ & 0,0464 & 0,0320 & 0,0015 & \\
\hline Prim. Jun & 698,21 & $2(1)$ & 0,0400 & 0,0160 & 0,0006 & \\
\hline Prim. FEv & 759,12 & $3(8)$ & 0,6091 & 0,0040 & 0,0024 & \\
\hline Prim. Mar & 775,97 & $4(1)$ & 0,1685 & 0,0120 & 0,0020 & 0,0120 \\
\hline
\end{tabular}

\begin{tabular}{c|c|c}
\hline FATOR C ANO & FATOR C ANO MEIO & FATOR C GERAL CANA \\
\hline 0,0149 & 0,0186 & 0,0168 \\
\hline
\end{tabular}


APÊNDICE F - Pastagem

\begin{tabular}{|c|c|c|c|c|c|c|c|}
\hline Data & $\mathrm{R}$ acum $\%$ & Estágio & R estag. Relativo & $\begin{array}{l}\text { RPS } \\
\text { estag. }\end{array}$ & Fator C & $\begin{array}{c}\text { FATOR C } \\
\text { ANUAL }\end{array}$ & $\begin{array}{c}\text { FATOR C } \\
\text { CICLO }\end{array}$ \\
\hline Prim. Set & 2,79 & $\$$ & $\$$ & $\$$ & $\$$ & $\$$ & 0,0049 \\
\hline Prim. Out & 6,75 & $\mathrm{D}(1)$ & 0,03960 & 0,2200 & 0,0087 & & \\
\hline Prim. Nov & 14,59 & $1(1)$ & 0,07840 & 0,1800 & 0,0141 & & \\
\hline Prim. Dez & 24,59 & $2(1)$ & 0,10000 & 0,0100 & 0,0010 & & \\
\hline Prim. Ago & 101,32 & $3(8)$ & 0,76730 & 0,0200 & 0,0153 & & \\
\hline Prim. Set & 102,79 & $4(1)$ & 0,01470 & 0,0700 & 0,0010 & 0,0402 & 1 \\
\hline Prim. Out & 106,75 & $\mathrm{D}(1)$ & 0,03960 & 0,0040 & 0,0002 & & \\
\hline Prim. Nov & 114,59 & $1(1)$ & 0,07840 & 0,0030 & 0,0002 & & \\
\hline Prim. Dez & 124,59 & $2(1)$ & 0,10000 & 0,0020 & 0,0002 & & \\
\hline Prim. Ago & 201,32 & $3(8)$ & 0,76730 & 0,0010 & 0,0008 & & \\
\hline Prim. Set & 202,79 & $4(1)$ & 0,01470 & 0,0010 & 0,0000 & 0,0014 & 2 \\
\hline Prim. Out & 206,75 & $\mathrm{D}(1)$ & 0,03960 & 0,0040 & 0,0002 & & \\
\hline Prim. Nov & 214,59 & $1(1)$ & 0,07840 & 0,0030 & 0,0002 & & \\
\hline Prim. Dez & 224,59 & $2(1)$ & 0,10000 & 0,0020 & 0,0002 & & \\
\hline Prim. Ago & 301,32 & $3(8)$ & 0,76730 & 0,0010 & 0,0008 & & \\
\hline Prim. Set & 302,79 & $4(1)$ & 0,01470 & 0,0010 & 0,0000 & 0,0014 & 3 \\
\hline Prim. Out & 306,75 & $\mathrm{D}(1)$ & 0,03960 & 0,0040 & 0,0002 & & \\
\hline Prim. Nov & 314,59 & $1(1)$ & 0,07840 & 0,0030 & 0,0002 & & \\
\hline Prim. Dez & 324,59 & $2(1)$ & 0,10000 & 0,0020 & 0,0002 & & \\
\hline Prim. Ago & 401,32 & $3(8)$ & 0,76730 & 0,0010 & 0,0008 & & \\
\hline Prim. Set & 402,79 & $4(1)$ & 0,01470 & 0,0010 & 0,0000 & 0,0014 & 4 \\
\hline Prim. Out & 406,75 & $\mathrm{D}(1)$ & 0,03960 & 0,0040 & 0,0002 & & \\
\hline Prim. Nov & 414,59 & $1(1)$ & 0,07840 & 0,0030 & 0,0002 & & \\
\hline Prim. Dez & 424,59 & $2(1)$ & 0,10000 & 0,0020 & 0,0002 & & \\
\hline Prim. Ago & 501,32 & $3(8)$ & 0,76730 & 0,0010 & 0,0008 & & \\
\hline Prim. Set & 502,79 & $4(1)$ & 0,01470 & 0,0010 & 0,0000 & 0,0014 & 5 \\
\hline Prim. Out & 506,75 & $\mathrm{D}(1)$ & 0,03960 & 0,0040 & 0,0002 & & \\
\hline Prim. Nov & 514,59 & $1(1)$ & 0,07840 & 0,0030 & 0,0002 & & \\
\hline Prim. Dez & 524,59 & $2(1)$ & 0,10000 & 0,0020 & 0,0002 & & \\
\hline Prim. Ago & 601,32 & $3(8)$ & 0,76730 & 0,0010 & 0,0008 & & \\
\hline Prim. Set & 602,79 & $4(1)$ & 0,01470 & 0,0010 & 0,0000 & 0,0014 & 6 \\
\hline Prim. Out & 606,75 & $D(1)$ & 0,03960 & 0,0040 & 0,0002 & & \\
\hline Prim. Nov & 614,59 & $1(1)$ & 0,07840 & 0,0030 & 0,0002 & & \\
\hline
\end{tabular}




\begin{tabular}{|c|c|c|c|c|c|c|c|}
\hline Prim. Dez & 624,59 & $2(1)$ & 0,10000 & 0,0020 & 0,0002 & & \\
\hline Prim. Ago & 701,32 & $3(8)$ & 0,76730 & 0,0010 & 0,0008 & & \\
\hline Prim. Set & 702,79 & $4(1)$ & 0,01470 & 0,0010 & 0,0000 & 0,0014 & 7 \\
\hline Prim. Out & 706,75 & $\mathrm{D}(1)$ & 0,03960 & 0,0040 & 0,0002 & & \\
\hline Prim. Nov & 714,59 & $1(1)$ & 0,07840 & 0,0030 & 0,0002 & & \\
\hline Prim. Dez & 724,59 & $2(1)$ & 0,10000 & 0,0020 & 0,0002 & & \\
\hline Prim. Ago & 801,32 & $3(8)$ & 0,76730 & 0,0010 & 0,0008 & & \\
\hline Prim. Set & 802,79 & $4(1)$ & 0,01470 & 0,0010 & 0,0000 & 0,0014 & 8 \\
\hline Prim. Out & 806,75 & $\mathrm{D}(1)$ & 0,03960 & 0,0040 & 0,0002 & & \\
\hline Prim. Nov & 814,59 & $1(1)$ & 0,07840 & 0,0030 & 0,0002 & & \\
\hline Prim. Dez & 824,59 & $2(1)$ & 0,10000 & 0,0020 & 0,0002 & & \\
\hline Prim. Ago & 901,32 & $3(8)$ & 0,76730 & 0,0010 & 0,0008 & & \\
\hline Prim. Set & 902,79 & $4(1)$ & 0,01470 & 0,0010 & 0,0000 & 0,0014 & 9 \\
\hline Prim. Out & 906,75 & $D(1)$ & 0,03960 & 0,0040 & 0,0002 & & \\
\hline Prim. Nov & 914,59 & $1(1)$ & 0,07840 & 0,0030 & 0,0002 & & \\
\hline Prim. Dez & 924,59 & $2(1)$ & 0,10000 & 0,0020 & 0,0002 & & \\
\hline Prim. Ago & 1001,32 & $3(8)$ & 0,76730 & 0,0010 & 0,0008 & & \\
\hline Prim. Set & 1002,79 & $4(1)$ & 0,01470 & 0,0010 & 0,0000 & 0,0014 & 10 \\
\hline Prim. Out & 1006,75 & $\mathrm{D}(1)$ & 0,03960 & 0,0040 & 0,0002 & & \\
\hline Prim. Nov & 1014,59 & $1(1)$ & 0,07840 & 0,0030 & 0,0002 & & \\
\hline Prim. Dez & 1024,59 & $2(1)$ & 0,10000 & 0,0020 & 0,0002 & & \\
\hline Prim. Ago & 1101,32 & $3(8)$ & 0,76730 & 0,0010 & 0,0008 & & \\
\hline Prim. Set & 1102,79 & $4(1)$ & 0,01470 & 0,0010 & 0,0000 & 0,0014 & 11 \\
\hline
\end{tabular}

APÊNDICE G - Milho em cultivo contínuo com palha enterrada

\begin{tabular}{c|c|c|c|c|c|c}
\hline Data & R acum \% & Estágio & $\begin{array}{c}\text { R estag. } \\
\text { Relativo }\end{array}$ & RPS estag. & Fator c & $\begin{array}{c}\text { FATOR } \\
\text { ANUAL }\end{array}$ \\
\hline Prim. Set & 2,79 & $\$$ & $\$$ & $\$$ & $\$$ & $\$$ \\
\hline Prim. Out & 6,75 & $\mathrm{D}(1)$ & 0,0396 & 0,2300 & 0,0091 & \\
\hline Prim. Nov & 14,59 & $1(1)$ & 0,0784 & 0,1900 & 0,0149 & \\
\hline Prim. Dez & 24,59 & $2(1)$ & 0,1000 & 0,1700 & 0,0170 & \\
\hline Prim. Ago & 101,32 & $3(8)$ & 0,7673 & 0,0400 & 0,0307 & \\
\hline Prim. Set & 102,79 & $4(1)$ & 0,0147 & 0,0200 & 0,0003 & $\mathbf{0 , 0 7 2 0}$ \\
\hline
\end{tabular}


APÊNDICE H - Soja em cultivo convencional e contínuo

\begin{tabular}{c|c|c|c|c|c|c}
\hline Data & R acum $\%$ & Estágio & R estag. Relativo & RPS estag. & FATOR C & \\
\hline Prim. Set & 2,79 & $\$$ & $\$$ & & & \\
\hline Prim. Out & 6,75 & $\mathrm{D}(1)$ & 0,0396 & 0,3500 & 0,0139 & \\
\hline Prim. Nov & 14,59 & $1(1)$ & 0,0784 & 0,3000 & 0,0235 & \\
\hline Prim. Dez & 24,59 & $2(1)$ & 0,1000 & 0,2000 & 0,0200 & \\
\hline Prim. Ago & 101,32 & $3(8)$ & 0,7673 & 0,2000 & 0,1535 & \\
\hline Prim. Set & 102,79 & $4(1)$ & 0,0147 & 0,0500 & 0,0007 & $\mathbf{0 , 2 1 1 6}$ \\
\hline
\end{tabular}

APÊNDICE I - Eucalipto ciclo para celulose

\begin{tabular}{ccccc}
\hline $\begin{array}{c}\text { Período/ } \\
\text { ano }\end{array}$ & & El 30 & RPS & Fator C \\
\hline 1993 & 1 & 6554,2 & 1 & 0,000153 \\
1994 & 2 & 6852,8 & 3,2307 & 0,000471 \\
1995 & 3 & 5853,7 & 0,6105 & 0,000104 \\
1996 & 4 & 6036,8 & 0,2763 & 0,000046 \\
1997 & 5 & 6324,4 & 0,0606 & 0,000010 \\
1998 & 6 & 8377,9 & 0,0075 & 0,000001 \\
1999 & 7 & 6662,2 & 0,1573 & 0,000024 \\
2000 & 8 & 4150,0 & 0,086 & 0,000021 \\
\hline Total & & & & $\mathbf{0 , 0 0 0 8 2 9}$ \\
\hline
\end{tabular}

APÊNDICE J - Script em Legal Fator LS

\{

Numerico declividade ("grade_de_declive");

Numerico fatortopografico ("rampa");

Numerico LS ("LS");

declividade = Recupere (Nome = "grad_decl"); 


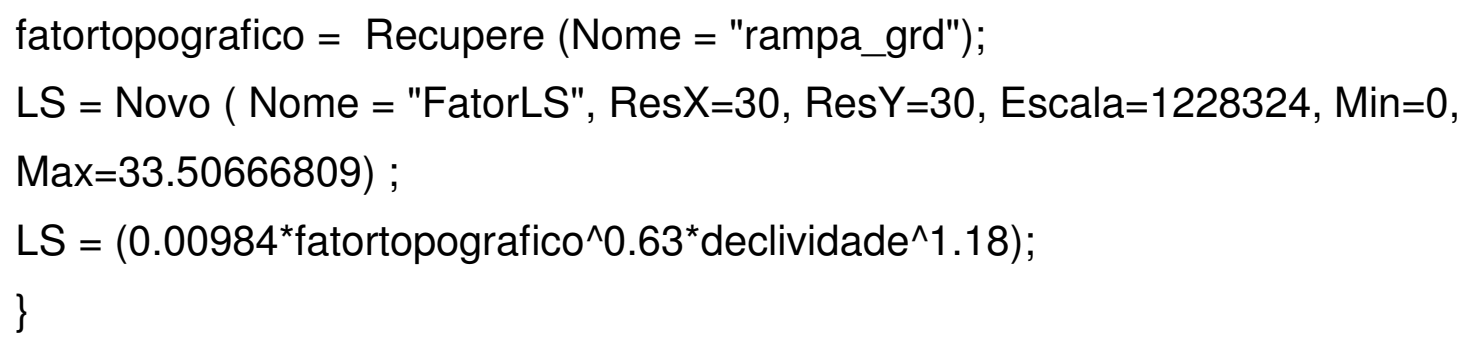

APÊNDICE L - Script em Legal CP atual -CP tolerável

\{

Numerico cp ("CP");

Numerico C ("C_toleravel");

Numerico EEL ("CPAa_CPt2");

$\mathrm{cp}=$ Recupere (Nome $=$ "cp");

$\mathrm{C}=$ Recupere $($ Nome $=$ "c_toleravel_rec" $)$;

$\mathrm{EEL}=$ Novo ( Nome $=$ "expec_erosao", ResX $=30, \operatorname{Res} Y=30$, Escala $=1228324$, Min=0, Max=1) ;

$\mathrm{EEL}=(\mathrm{cp}-\mathrm{C})$;

\}

APÊNDICE M - Script em Legal Potencial Natural a erosão PNE

\{

Numerico Topografico ("LS");

Numerico Erodi ("fatork"); 
Numerico PNE ("pot_nat_ero");

Topografico $=$ Recupere $($ Nome $=$ "FatorLS_rec");

Erodi $=$ Recupere $($ Nome $=$ "K" $)$;

PNE $=$ Novo $($ Nome $=$ "erosao_natural2", ResX $=30, \operatorname{Res} Y=30$, Escala $=1228324, \operatorname{Min}=0, \mathrm{Max}=100000)$;

$\mathrm{PNE}=(7099$ * Topografico * Erodi);

\}

APÊNDICE N - Script em Legal EUPS Baguaçu

\{

Numerico Erodi ("fatork");

Numerico Topografico ("LS");

Numerico C ("grade_uso");

Numerico P ("praticas_baguacu");

Numerico EUPS ("grade_EUPS");

Topografico $=$ Recupere $($ Nome $=$ "FatorLS_rec");

Erodi $=$ Recupere $($ Nome $=" K ")$;

$\mathrm{C}=$ Recupere $($ Nome $=$ "uso" $)$;

$\mathrm{P}=$ Recupere ( Nome = "pratic_baguacu");

EUPS $=$ Novo ( Nome $=$ "eups_baguacu", $\operatorname{Res} X=30, \operatorname{Res} Y=30$, Escala $=1228324$, Min=0, Max $=100000)$;

EUPS $=\left(7099{ }^{*}\right.$ Erodi ${ }^{*}$ Topografico $\left.{ }^{*} \mathrm{C}{ }^{*} \mathrm{P}\right)$;

\} 